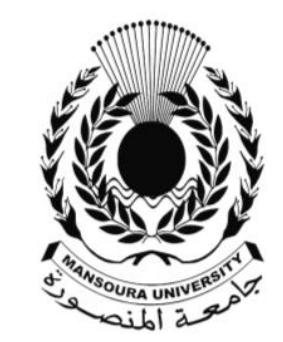

جامعة المنصسورة الملند

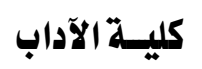

\title{
" رسالة فى شرح الجنة والنار " \\ لعزيز الدين النسفى \\ " دراسة وترجمة ”
}

$$
\begin{aligned}
& \text { إعــداد } \\
& \text { دكتور / دعاء على عبداللطيف المرسى }
\end{aligned}
$$

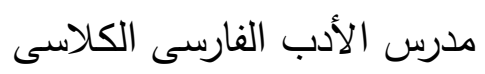

$$
\begin{aligned}
& \text { كلية الآداب - جامعة المنصورة }
\end{aligned}
$$

مجــلة كلــية الآداب - جامعــة المنصــورة

$$
\text { العدد الخامس و الخمسون - أغسطس عا+بان }
$$




\section{" رسالة فى شرح الجنة والنار " لعزيز الدين النسفى دراسة ترجمة}

\section{د/ دمائ على عبداللطيف المرسى}

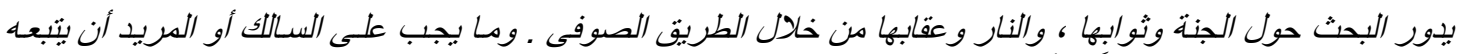

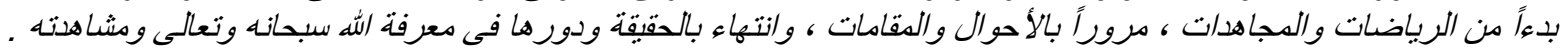

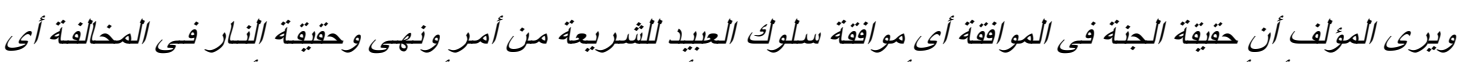

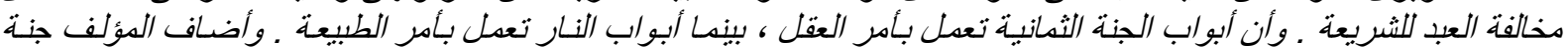

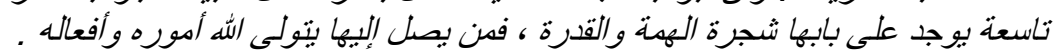

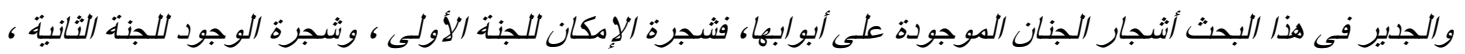

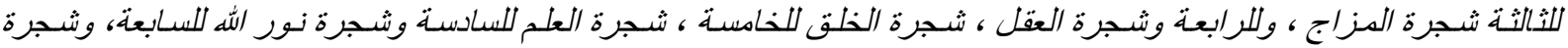

المشا هدة للثامنة

\section{Abstract}

The present research revolves around Paradise and its Reward and Hell with its punishment through the Sufi route. It also hands what the advocate should follow starting from sports and struggles through conditions and Maqamat and ending with truth and its role in viewing and recognizing Allah Almighty.

The author views the truth of paradise as manifest in the worshipper's concord with jurisprudence (Share'a) including "dos's" and "don'ts". Add to this the truth of hell in deviating from jurisprudence (Share's). The research also holds that the eight doors of paradise function according brain orders while those of hell function according to Nature. The researcher further adds a nineth paradise at whose door there is the Zeal and Ability tree; this who reaches it Allah Almighty takes care of his affairs and deeds.

What is innovative in this research are the paradise Trees found at its doors as the Ability Tree for the first paradise, that of existence for the second, that of the Mood for the third, that of the bran for the fourth, that of creation for the fifth, that of science for the sixth, that of Allah's light for the seventh and that of viewing for the eighth.

جـاء القسـم الأول ؛ تحت عنوان : الجنـة

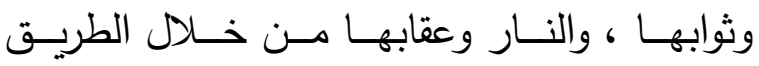
الصـوفى • ومـا يجـب على السـالك أو المريـد أن يتبعـه بـدءاً مـن الرياضـات والمجاهـدات، مـروراً بـالأحوال والمقامـات وانتهـاء بالحقيقة ودورهـا فى معرفة الله سـبحانه وتعـالى ومشـاهدته مـن خـلال علم اليقين وعين اليقين أما القسم الثانى : فهو ترجمة رسالة " فى شـرح الجنـة والنـار " مـح تأصسيل الآيـات القرآنيـة

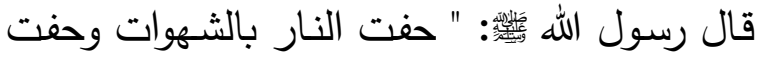
الجنة بالمكاره " صدق رسول الله ـ فالشهوات التى حفت بها النار تضم المال والنساء والأبناء والجاه، أمـا المكـاره التـى حفـت بهـا الجنــة فهى الصـــر والفقر والألم والغدر ..

$$
\begin{aligned}
& \text { من هنـا كان اختيارى لرسـالة " فى شـرح } \\
& \text { الجنة والنـار " لعزيز الدين النسفى والتى تقع فى } \\
& \text { ستة فصول حيـث تدور حول الطريق الصسوفى } \\
& \text { فمن خلالـه يبلـخ السـالك درجـات الجنـة أو دركات } \\
& \text { النار • وقد قسمت البحث إلى قسمين : }
\end{aligned}
$$


المعـروف بالشــيخ عزيزالـدين النسـفى مسن كبـار الصوفية فى القرن السـابع الهجرى ولد فى نسف (نخشـب اليوم) بـإقليم خـوارزم وقضسى جـزءاً مـن حياته فيه .

فكـان الشـيخ يعسيش فـى بــلاد ببخــارى

وخوارزم التى تُعد من أعظم مراكز العلم والأدب والمعرفة آنذاك حيث هرب من فتتة المغول وقصد أبرقوه ـ توجه إلى بخارى وأقام فيها سنوات طوال حتى بلـن مـدن خراسـان ، واعتكف بجـوار مرقد

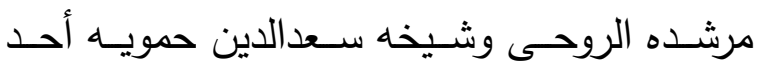
تلاميذ محيى الدين بن عربى ، أما الشيخ النسفى فقد قيل إنه قابل تلميذ ابن عربى الثيخ صدرالدين القونوى ، ومن خـلال تتبع أعمال النسفى تتجلى أفكار ابن عربى فى جل كتاباته .

أمـا عـن مـذهب النسـفى ، فكـان يعتــق

المـذهب الثـيعى وأفكاره والتى تتجلى فى كتاب الشيخ المسـى بـ " كثف الحقائق " ؛ حيث قدم

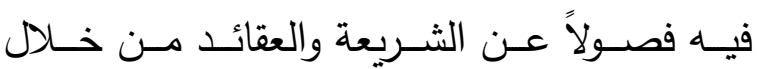

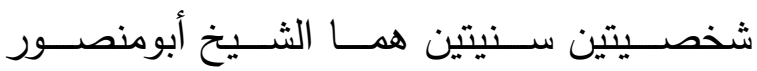
الماتريـدى والثـيخ محمد الغزالـى وشخصـية شيعية

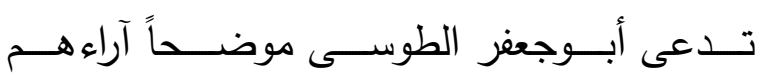
واجتهـاداتهم حـول شـريعة وعقائــــــــل طائفــة منهما (1) وكان النسفى أيضـاً أديباً وشاعراً ـ أمسا عن بعض مؤلفات الشيخ التى كتبت أغلبها بالفارسية هى : 1
والأحاديث القدسية والنبوية الشريفة وأقوال رجالات التصوف الواردة فى الرسالة . القســم الأول : الجنـة وثوابهـا والنـار وعقابها مـن خلال الطريق الصوفى :

\section{ويتكون من تمهيد وأربعة فصول .}

أمـا التمهيـــ فيـدور حـول مولـد الثـيخخ وأسـفاره

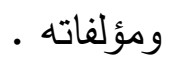

الفصـلـل الأول : حقيقــة الجنــة والنـار وأوصـافها

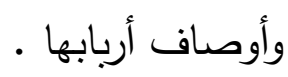

الفصـل الثـانى : أبـواب الجنـة والنـار وأشـجارها وأربابها

الفصل الثالث : الجنة أو النار والطريق الصوفى الفصـل الرابـع : الجنـان عند عزيزالـدين النسـى وكيفية الوصل إليها .

ثم الخاتمة ، فقائمة المصادر والمراجع . القسم الأول : الجنـة وثوابها والنـار وعقابها من خلال الطريق الصوفى : تمهيــ : عزيزالـدين النسـفى ، المولد والأسـفار والمؤلفات : يقول المستشرق الفرنسى " ماريز ان موله ": ليس هناك دراسة جادة ودقيقة عن حياة النسفى بتفصيلاتها والتى مرت عليه اللهم إلا ما ذكر عن الاختلاف عن ولادته ووفاته أو أسفاره التى عانى

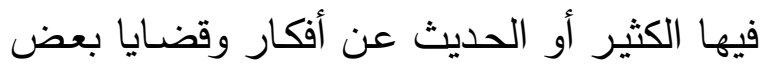
مؤلفاتـهـه ـ كـان الشــيخ عبــدالعزيز تحمد النسـفـى 
وردت الجنـة فـى القـرآن الكـريم بمعـان

مختلفة ، فالجنة تعنى البستان كما قال سبحانه

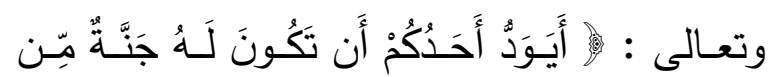

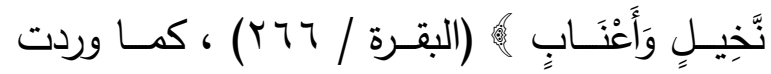

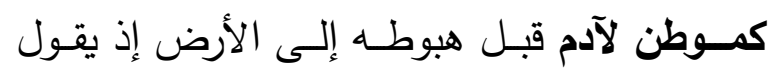

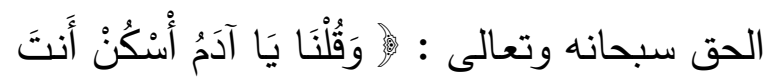

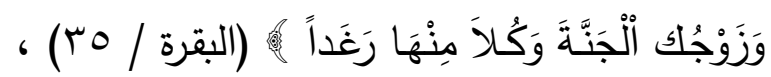

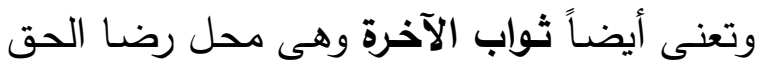

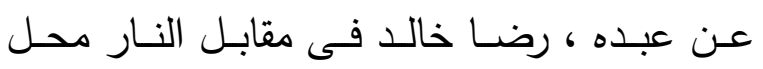

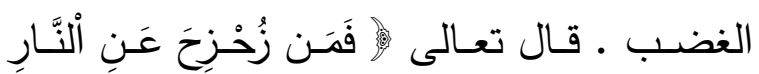

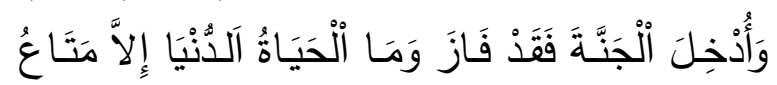

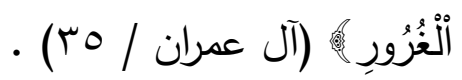

والجنـة هى النعيم المستور المتجدد مـع

الأنفـاس ، وهـى دار الفضــل والقربــة والجمـال

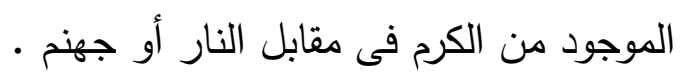

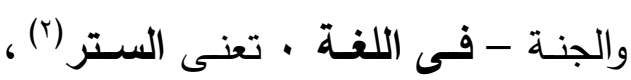

لذللك فكل من له رتبة الستر فهو جنة ، فالعبد هو

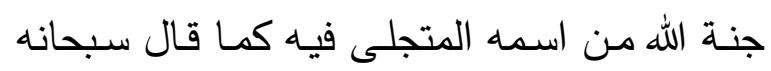

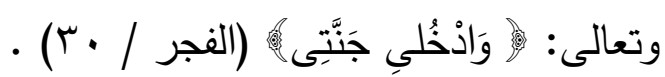
أمـا النــار فقـد وردت فـى القـرآن الكـريم

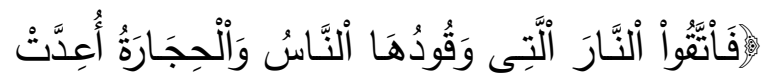

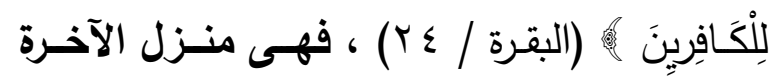
للأثـقياء الظـالمين ، وهـى نـار حقيقيـة وقودهـا

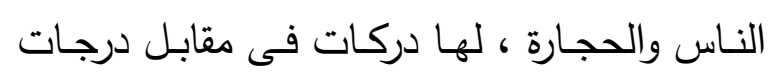

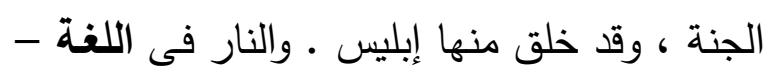

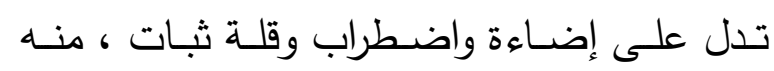

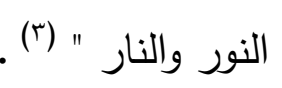

r - زبـدة الحقائق ، وهو ملخص مـن رسـالة المعاد . r - كتاب التنزيل أو بيان التنزيل . ع - - مجموعة رسائله المعروفة بالإنسان الكامل

$$
\begin{aligned}
& \text { ○ - منازل السائرين . } \\
& 1 \\
& \text { • V }
\end{aligned}
$$$$
\text { 1 - أسرار التصوف وخواص الحروف . }
$$$$
9
$$$$
\text { • }
$$$$
\text { (1) - 1 - سلوك مقامات . }
$$$$
\text { r ا }
$$

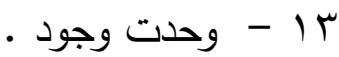

أما عن رسالة " دربيان بهشت ودوزخ " -

محل الدراسة - فهى ضمن عشرين رسالة جمعهم الشيخ فى كتاب الإنسان الكامل وقام بتصحيحه

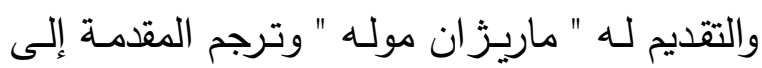
الفارسية د. سيد ضياء الدين دهثيرى .

وقد قام الثيخ بكتابـة هذه الرسائل نزولاً

على رغبة سـالكى الطريق لتكون نبراساً ومؤنساً ودستوراً لهم فى الطريق إلى الله .

الفصـل الأول : حقيقـة الجنـة والنــاروأوصـافها وأوصاف أربابها 
الآيـة الكريمـة السـابقة ليوضـح أن جهنم يـدخلها الإنسان بنفسه الحيوانية .

وتفسير الآيـة الكريمة منْ خلقه لجهنم -

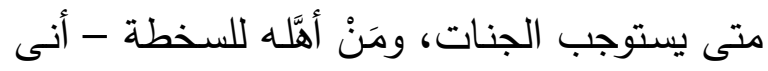

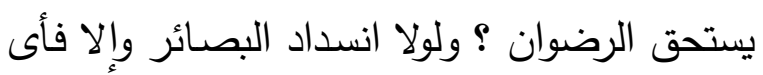

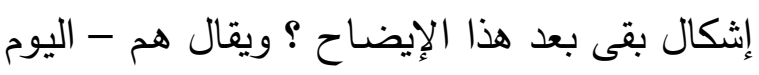

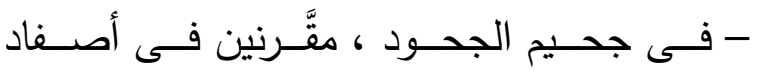

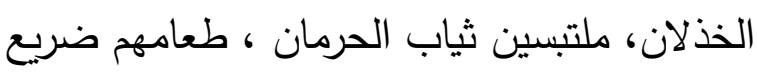

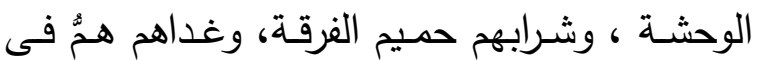
جحيم الحرقة ـ فهم لا يفقهون معانى الخطاب ، الحنه وليس لهم تمييز بين خواطر الحق وبين هواجس النفس ووساوس الشيطان ، ولهم أعين لا يبصرون بها شواهد التوحيد وعلامات اليقين ، فلا ينظرون إلا من حيث الغفلة ، ولا يسمعون إلا دواعى الفتنة ، ولا ينخرطون إلا مع من سلك ركوب الثهوة . "

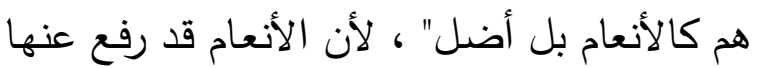
التكليف ، وإن لـ يكن لها وفـاق الشـرع ، فليس

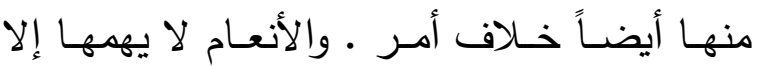

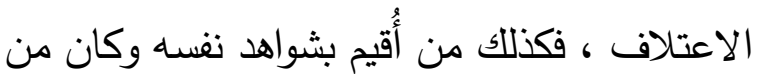

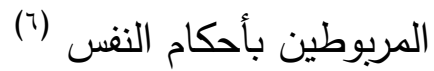

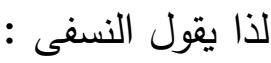
"... ومن ثم فإن المرور على النار سوف يكون

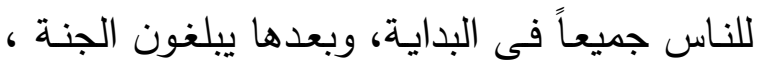
ويظل البعض فى النار ولا يستطيع تركها ، ويعبر

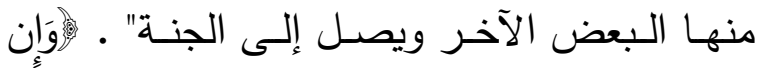

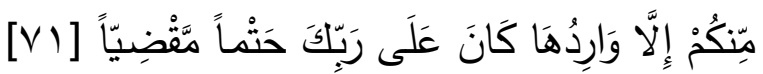

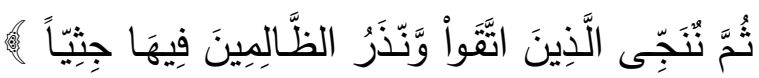

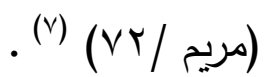

ويتحـدث عزيزالـدين النسـفى عـن حقيقـة

الجنة والنار قائلاً :

" اعلم - أعزك الله فى الدارين - أن حقيقة الجنة الموافقة ، وحقيقة النار المخالفة ، وحقيقة الخير إدراك المراد، وحقيقة الثر عدم إدراك المراد.... فكل الأقوال والأفعال المقبولـة والأخلاق الحميدة

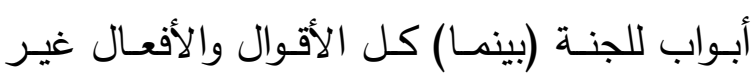

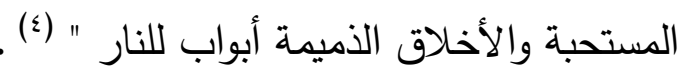
أى أن اسـتمرار الإنســان فـى ارتكــاب الذنوب والمعاصى ، والعدول عن الاستقامة يؤدى الإنى بـه إلى النـار ، مثلمـا حدث لإبليس الذيى كـان

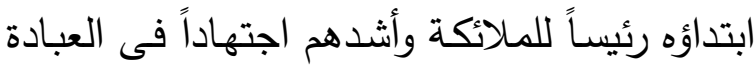

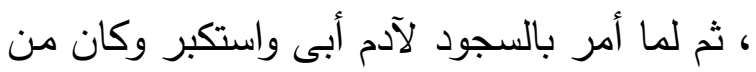

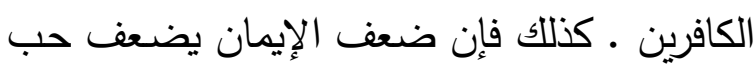
الله تعالى ، ويقوى حب الدنيا فى قلبه ويستولى لـ لإنيان

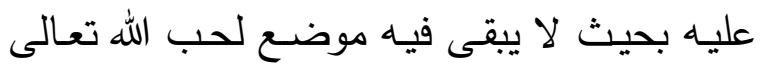

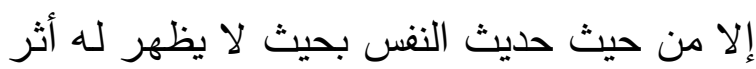

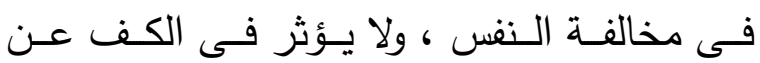
المعاصى ولا فى الحث على الطاعات ، فينهمك فى الثـهوات وارتكاب السيئات ، فتتراكم ظلمات

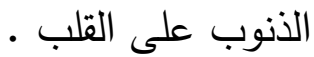

\section{يقول النسفى فى ذلك :} " أيها الفقير ! يظل أغلب الناس فى النار ، ولا

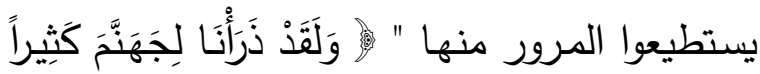

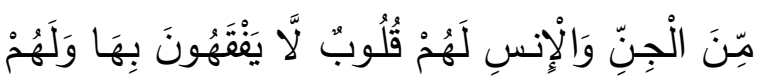

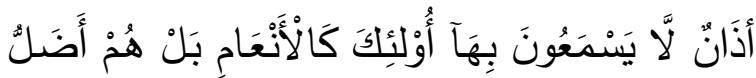

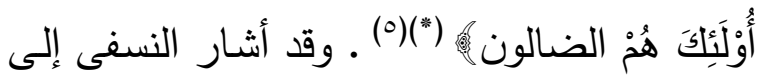


فالمشركون بالله هم الثوية ، والشـاكون هم الذين لا يدرون أن لهم إلها أو لا إله لهم ويشكون فى هـ له

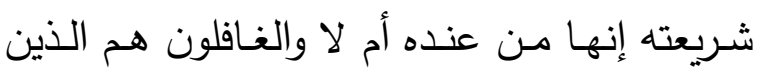

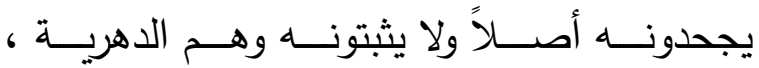
والمؤثرون شهواتهم هم المنهمكون فى المعاصسى لتكذيبهم برسـل الله وأمـره ونهيـهـ ، والثــاقون هـم القتالون أنبياء الله وسائر الداعين لهه المعذبون من ينصسح لهم أو يذهب غير مذهبهم ، والمصيرون رغبـتهم المنكـرون للبعـث والحسـاب ، والعـاتون الذين لا يبالون بأن يكون ما منهم حقاً أو باطلاً فلا يتفكرون ولا يعتبرون ولا يستبدلون ، و الله أعلم

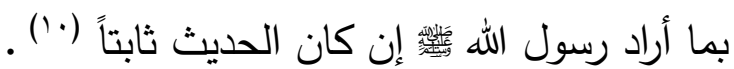
أما عن أسماء النار وأبوابها ، فقد اختلفوا

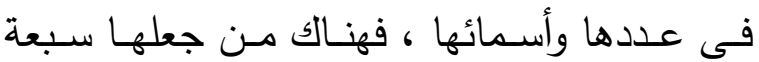
وآخـرون جعلوهـا ثمانيـة ـ وحقيقــة الأمـر وطبقـاً لورود آيات قرآنية فهى سـبعة أبـواب ، فالبـاب الأول يســـى جَهَنَّْم لأنـهـ يتجهم فى وجوه الرجال والنسـاء فيأكل لحومهح ، لهول وهو أهون عذاباً من غيره ، والباب الثانى يقال له

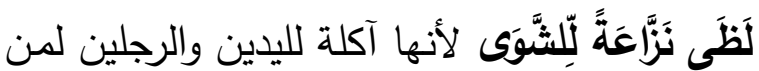
أعرض عن التوحيد ، والباب الثالث يقال له سَقَر ، وإنما سمى سَقَر لأنه يأكل لحوم الرجال والنساء لا يبقى لهم لحماً على عظم ، والباب الرابع يقال

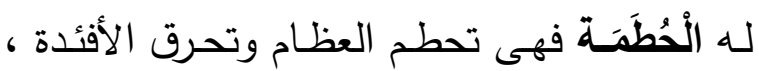

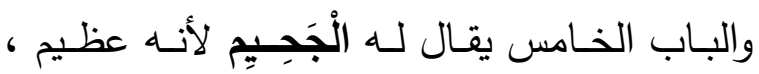

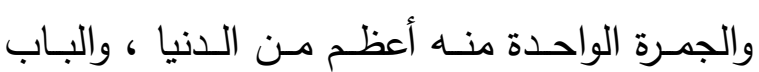
السادس يقال له السَعِير لأنه يسعر من لم يسعر

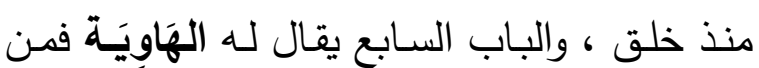

فكلُّ يرد النار ، ولكن لا ضير منها ولا احتباس

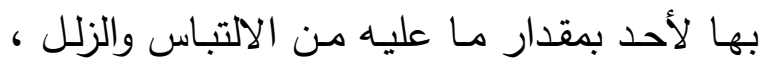

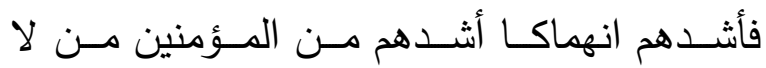
ينجيهم، ويترك الكفـار فيهـا بنعـت الخيبـة عـن

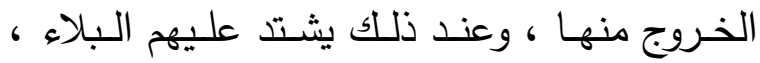
وتطبق عليهم أبواب جهنم ويتقطع منهم الرجـاء

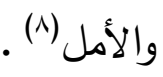

واستشـهاد النسفىى بالآيـة المـكورة سـلفاً ،

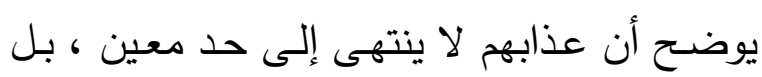

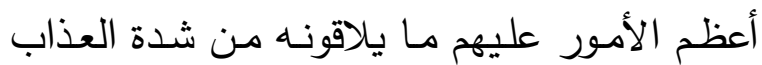
حسرة فوت نعيم الجنة وقوت لقاء الله تعالى وفوت رضاه ، مع علمه بأنهم باعوا ذلك بشهوات حقيرة

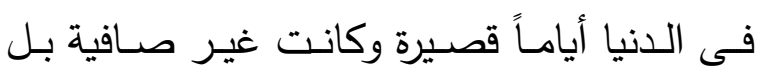

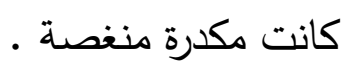

\section{الفصل الثـاذى : أبـواب الجنــة والنـاروأشـجـارهـا

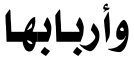

قال رسول الله

منها لمن سلَّ السيف على أمتى أو قال أمسة محمد

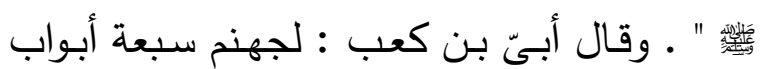
أشدها غماً وكرباً وحراً ، وأنتنها ريحا للزناة الذين ركبوا بعد العلم • رواه أبونعيم الحافظ ـ فقد ورد فى كتاب يقظة أولى الاعتبار : ،ـدخل النـار سـبعة ، جزء أشـركوا بـالله ، وجزء شكُّوا فى الله ، وجزء غفلوا عن الله ، وجزء آثـروا شـهواتهم علـى الله ، وجـزه شـفوا غـيظهم بغضب الله ، وجزء صيروا رغبتهم بحظهم عن الله

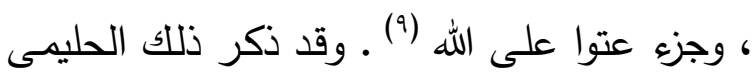
فـى كتـاب منهـاج الـدين قـائلاً : فـإن كـان ثابتـاً 
وقد أجاد الثيخ فيها ، فلم يتعرض أحد من قريب

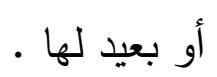

يقول النسفى : " اعلم أنه قيل إن هناك ثمان جنان ، واعلم الآن أنه فى بداية كل جنة (توجد) شجرة ،

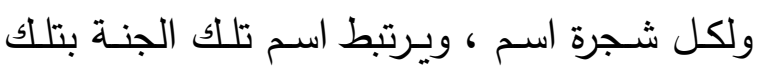
الثجرة ، فاسـم الثـجرة الأولى شـجرة الإمكـان ، واسم الثجرة الثانية شجرة الوجود ، واسم الثجرة الثالثة شجرة المزاج ، واسم الثجرة الرابعة شجرة العقـل ، واسـم الثـجرة الخامسـة شــرة الخلـق ، واسم الشجرة السادسة شجرة العلم ، واسم الثجرة

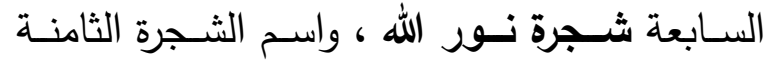
شجرة المشاهدة"(10) - (10)

فقد ورد فى كتاب الإحياء عن رسول الله

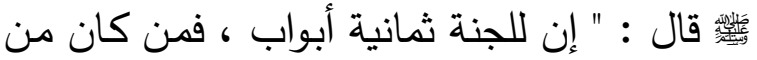
أهل الصـلاة دعى من بـاب الصـلاة ، ومن كـان من أهل الصيام دعى من باب الصيام ، ومن كان من أهل الصدقة دعى من باب الصدقة ، ومن الصناب كان من أهل الجهاد دعى من باب الجهاد ، فقال

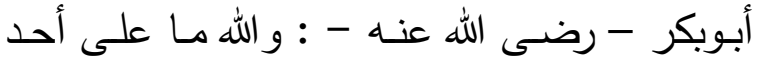
من ضرورة من أيها دعى ؟ فهل يدعى أحد منها

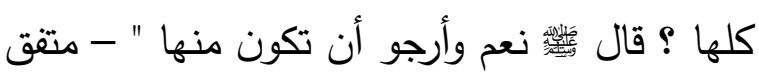
عليه (17) كان

ويـرى ابـن قيم الجوزيـة (Vا) ـ أن للجنــة

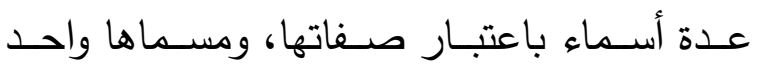

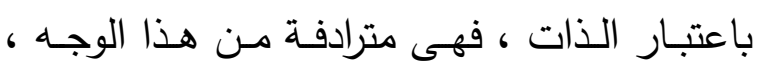
وتختلف باعتبار الصفات فهى متباينة مـن هذا

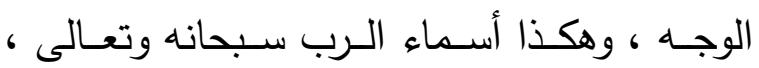

وقع فيه لم يخرج منه أبداً وفيه بئر اللهب إذا فتح تخرج منه نار تستعيذ منه النار (') ويورد ابن عربى باباً ثامناً للنار وهو باب

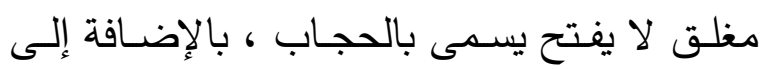

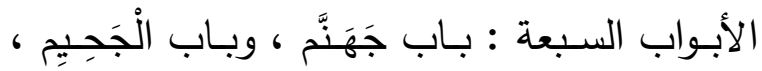

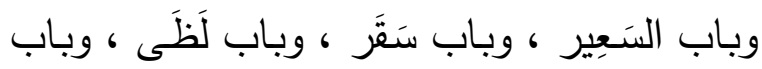

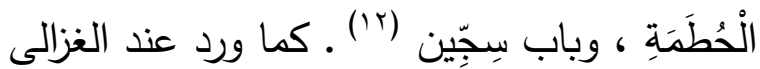

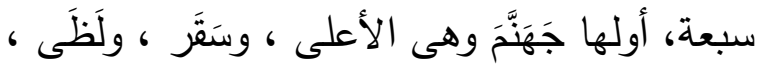

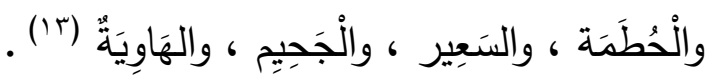
يقول النسفى :" اعلم أن البعض يقول إن أبواب

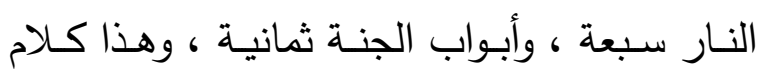
صحيح أيضاً ، لذا فإن المشاعر الإنسانية ثمانية

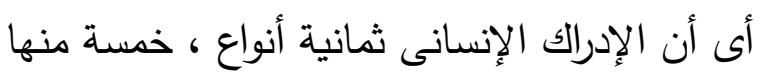
: الحواس الظاهرة ، والخيال ، والوهم ، والعقل ، وكل شعء يدركه الإنسـان ويفعله ، يدرك خمسـة

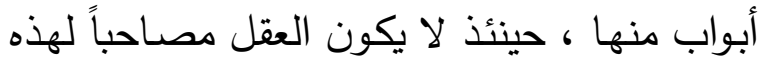

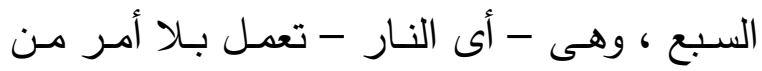
العقل ، بل تكون أبواب النار السبعة بأمر الطبيعة

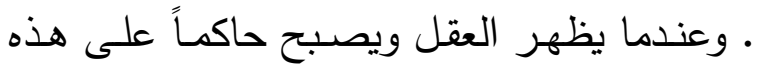

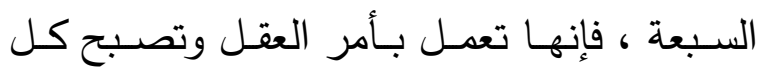

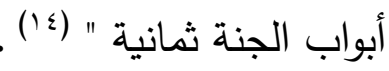
ويلاحظظ أن عزيزالدين النسـفى لــ يــكر أسماء النار كما ذكرها غيره، وكان حديثه عنها مجرداً كاسـم عام ، بـل كـان حديثه عن الجنـان

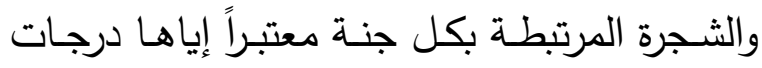
يرتقى إليها الساللك حسب تدرجه فى المنازل من خلال المجاهدات والرياضات والأحوال والمقامات لئات لئات 


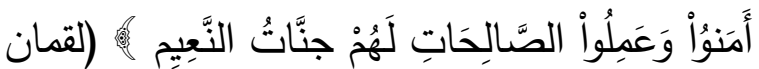

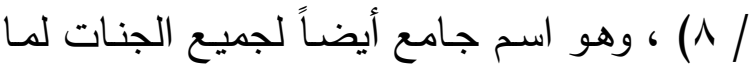

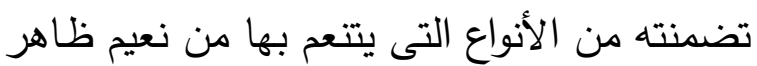

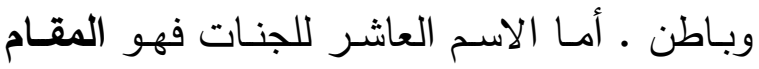

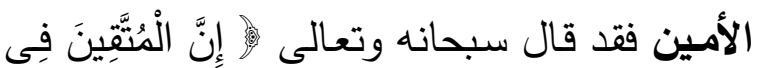

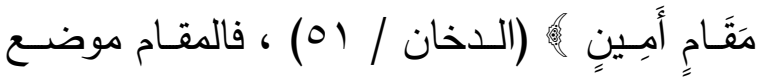

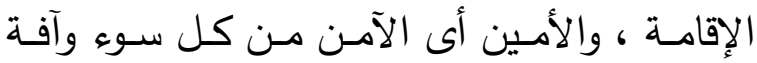
ومكروه • بينما الاسم الحادى عشر والثانى عشر الإن فهو مقعد صـدق وقدم صـدق حيث قال الحق

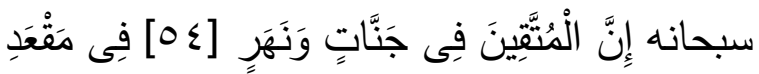

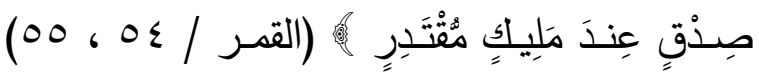
أى يدخل العبد مدخل صدق ويخرج مخرج صدق

ويـرى النسـفى أن الجنــة أو النـار طريـق يوصـل

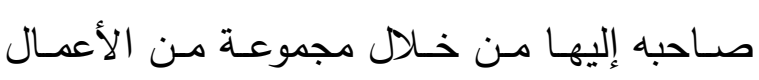
الظاهرة والباطنة .

\section{الفصل الثالث : الجنة أو الناروالطريق الصوفى}

يبدأ المؤلف رسـالته بالحديث عن العهد

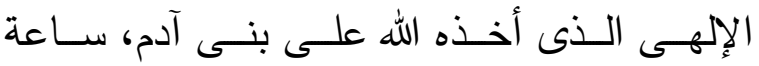

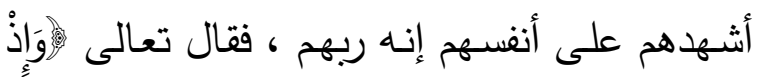

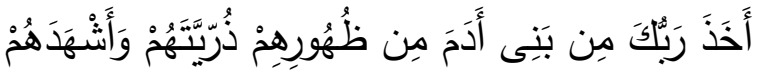

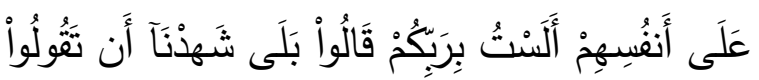

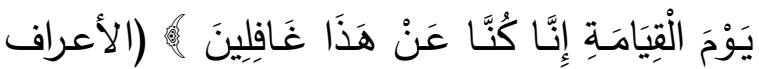

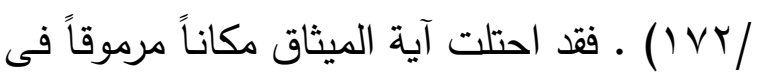
الفكر الإسـلامى بصفة عامـة ، والتصوف بصفة خاصة ، فهذا الآية تدل دلالة واضحة على وجود الإلها

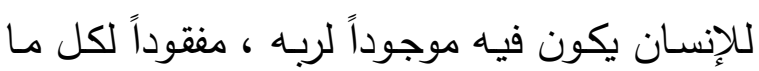

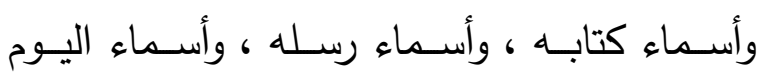

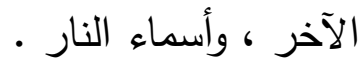
والجنان عنده اثنا عشر جنة، مستنداً فى ذللك إلى آيات من القرآن الكريخ ، فالاسم الأول :

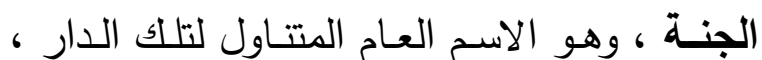
وما اشتملت عليه من أنواع النعيم واللذة والبهجة التها والسرور وقرة العين ـ أما الثانية فهى دار السـلام

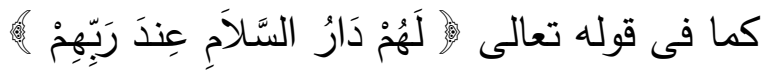

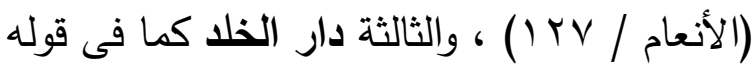

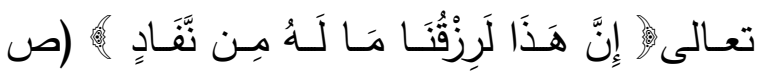
/ اءo) ، والرابعة دار المقامسة فقال الحق سبحانه

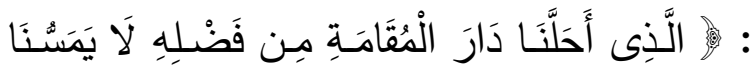

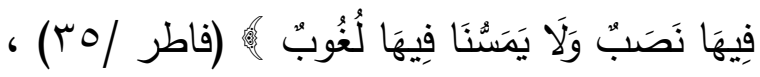

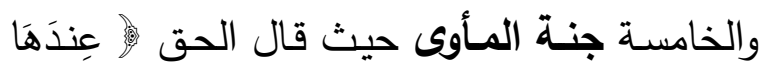

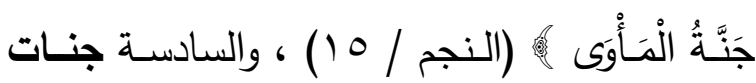

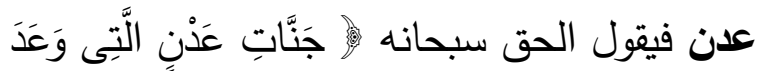

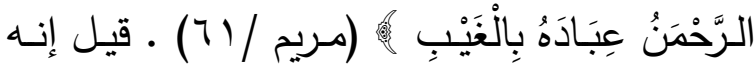

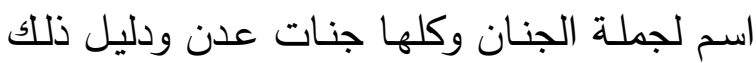

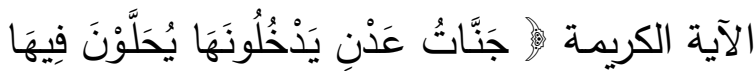

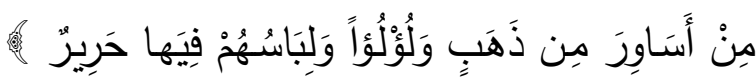
(فاطر / مبا) ) حيث تعنى عدن : الإقامة والدوام

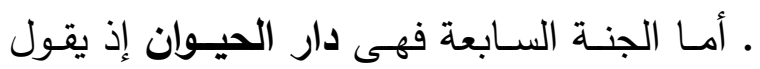

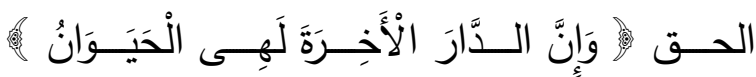

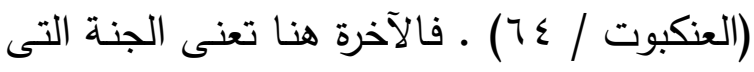
لا موت فيها ـ والجنة الثامنة هى الفردوس حيث

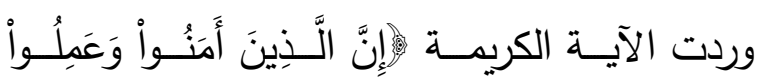

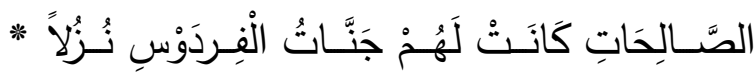

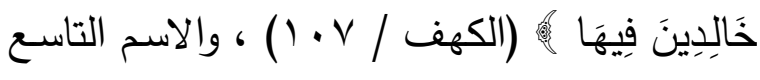

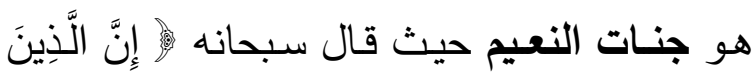


أصنام للنفس ، وحجاب فى طريق السالك لا يحيد

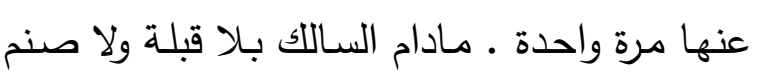
فإنه يصبح ظاهراً متجلياً وصافياً ومجرداً ـ ف " الله فرد ويحب الفرد " (9) .

وهذا يعنى أنه يجب على المريد أن ينسلخ

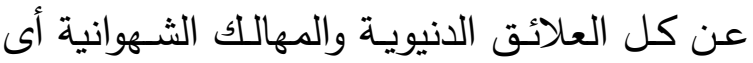
الخـروج عـن العـادات ، فتـرك العـادة هـى دليـل

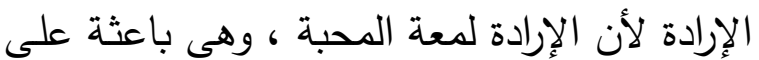
التوجه إلى المطلوب الحقيقى طوعاً وكرهاً . إذن الإرادة هـى بدايــة طريـق السـالكين لطريق الطريقة لأنها مقدمة كل عمل، يقول أبو مححد

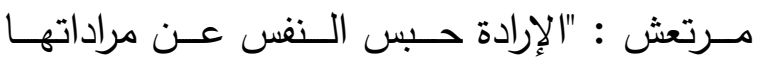

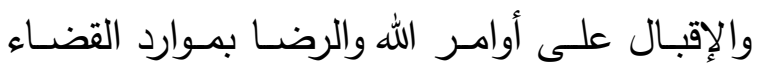
عليه " (r.).

فعلى السـالك أن يبـأ بـالإرادة الذاتيـة إذا

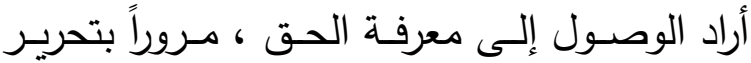
الإرادة من النفس وسلطانها عن طريق المجاهدات والرياضـات ، وصـولاً إلى أدب الحضـرة الإلهيـة

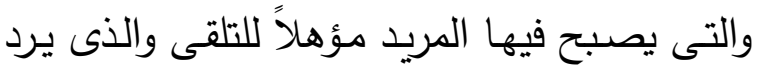
من الحق (r) ماتى وذللك حتى تتكثف الحجب حيث إن الحجاب باب

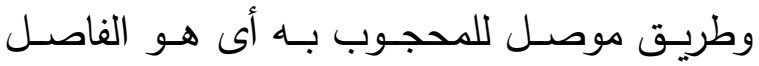

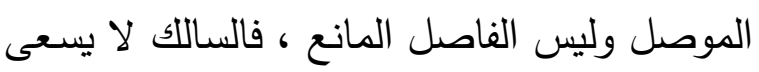
إلا إلـى الوجــه الإلهـى فهـو مطلوبـهـ ، فيكـون الحجاب كل مـا يقف فى طريق رؤيته المباشـرة للوجه الإلهى ـ كان سرى السقطى يقول: " اللهح

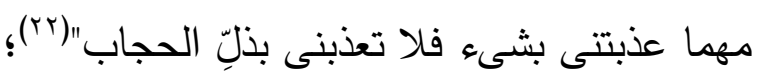
حيث لا يتم ذلك الكثف إلا بإزالة عوائق الدنيا
يقول النسفى :" أيها الفقير ! تلك الأمانة التى عرضت على كل الموجودات ، فأبوا جميعاً ولم

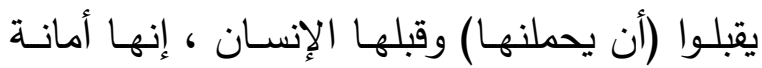

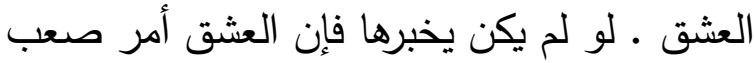

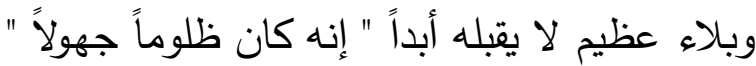

ويرى النسفى هنا أن أمانـة التكليف التى

قبلها الإنسـان وحده أودت بـه إلى صسعوبة حمل المله الأمانة كان ظلوماً جهولاً ، والأمانة عند المؤلف الألف هى أمانة العشق التى ينجذب إليها السالك نحو

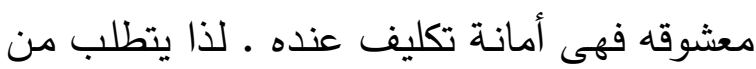

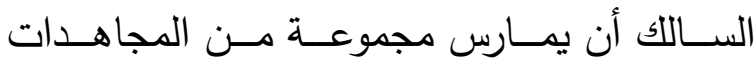

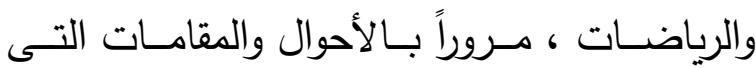
تعتريـه ، وصـول إلى الحقيقة المتمثلة فى الرؤيـة والمشــاهدة والمعرفـة ، ولا يـتـم ذلــك إلا بمحبــة الخالق أو عشقه حسب درجة المحب . ويرسـم النسـفى طريـق السـاللك أو الفقيـر الذى يؤدى بـه إلى دخول الجنة بدرجاتها محذراً إياه من النار بدركاتها قائلاً : " اعلم أن للنـار والجنـة منـازلاً ، وطريق السـالكين

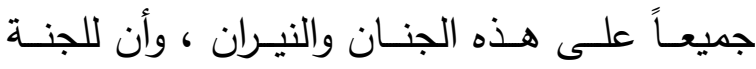
والنار بلهاء أيضـاً ، ولهما عقلاء أيضـاً ، ولهما كــللك عشـاق ـ فالنـار والجنــة لهــا مخـالفون ومناسبون ، ولابـــ أن يكون للنـار والجنــة عقـلاء مناسبون ومهاجرون ، وأن لهما عشـاق للحجاب

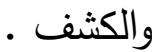
أيها الفقير ! العشق نـار تقع فى قلب السـالك . والأسباب الظاهريـة والأفكار الباطنية للسالك كلها 


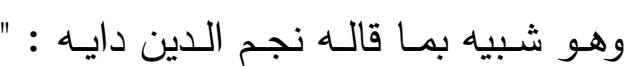
العقل لا يمكن أن يدرك كنه ذات الحق وصفاته،

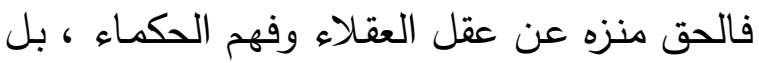

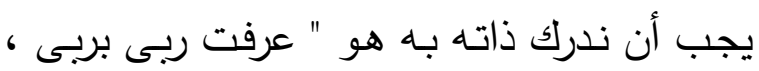
ولولا فضل ربى ما عرفت ربى " (ro) . ويؤكد النسفى على ذلك قائلاً :

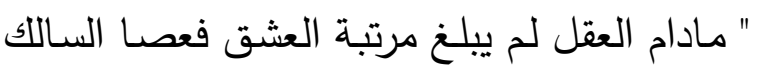
إما أن تعمر عالمه وإما أن تجعل أعماله الدنيا.

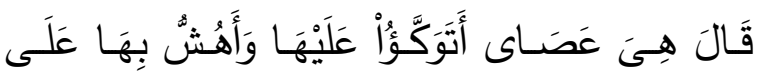

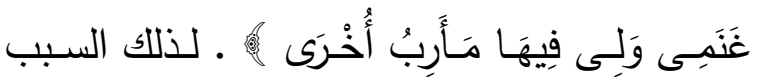

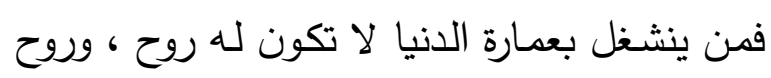

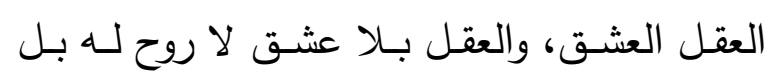

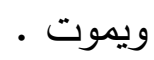

لو لم يوجد القلب فكيف يبنى العشق وطنا ولو لم يوجد العشق فأى عمل يكون للقلب

أى أن التجربــة الصــوفية المنبثقـــة عـن

مجاهدة السالك لنفسه تدخل فى معركة عدوها فيها

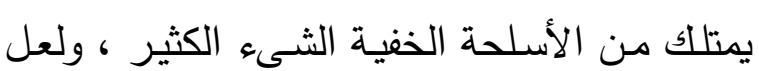

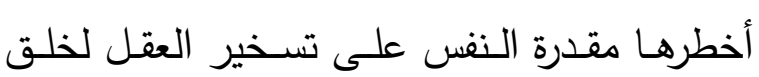

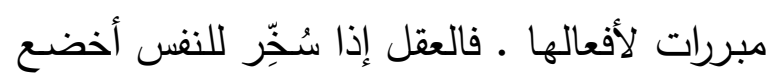
الإنسان لها ، فكل ما يقوم به الإنسان يخيل إليه

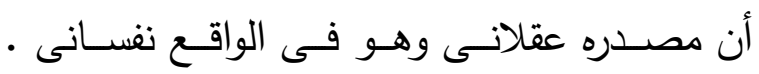

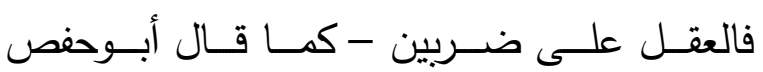

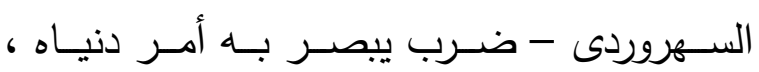

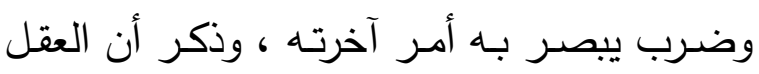

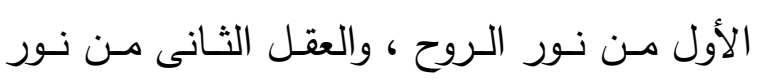

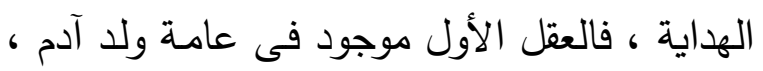

من زهد فيها واعتزال الخلق وجهاد الثيطان وكسره

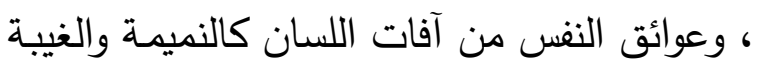
وسـب المسـلم واللعـن والكــب والغضـب والكبـر والحســ والريـاء وطـول الأمـل وسـببه وذم أفعـال الجوارح من شره الطعام والفضول من القول ـ ولا

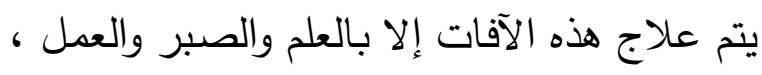

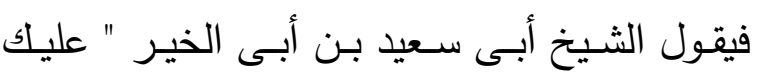
بذبح النفس وإلا فلا تشغل بترهات الصوفية " (rT)

ويؤكـد النسـفى فـى كلامـه على أن دواء

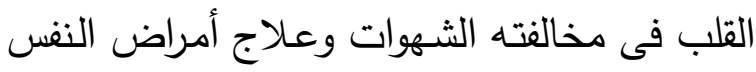
بتداوى كل خصلة منها بضدها ، فالقلب لا ينبت

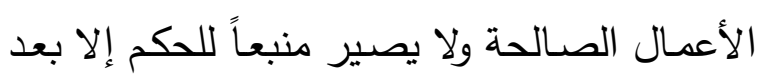
تتقيته من عيوبه وتطهيره مـن الصفات الذميمـة التى هى منبت الفواحش • وكل قلب لا تدخلـه محبة الله فهو مريض ، وعلامة محبة الله أن لا يؤثر عليه الدنيا ولا غيرها من المحبوبات. ويواصل النسفى حديثه قائلاً : " أيها الفقير ! يرد الساللك خطاب بأن انبذ العقل،

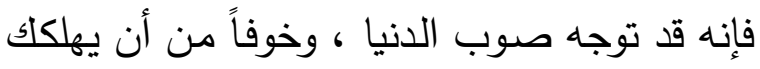
أدر وجهاك تجاهنا ، فإن لم يستطع السالك أن ينبذ

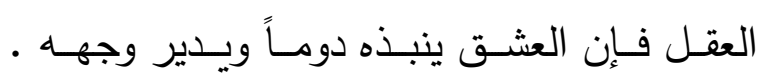
فالسالك لا عشق له فى البداية . وعندما يبلغ السالك مرتبة العشق فإنه يلقى بالعقل ، وعندما يلقيه يراه الثعبان فيخاف ، ويكون خوفه لئه

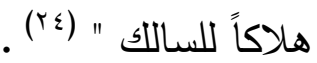


كل من احتسى قطرة من كأس عشقلك، أفضـل للثمل والحائر إلى يوم القيامة "(·r) .

ويستند النسفى إلى الآية الكريمة : عَّالَ

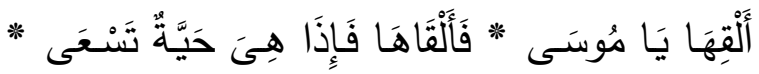

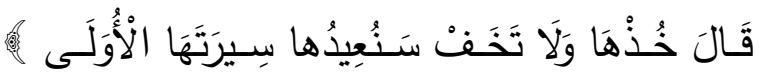

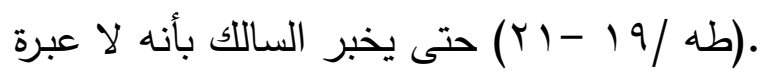
بما يُوهِم ظاهر الأشياء ، فقد يوهم الظاهر بشىى ثـم يبـدو خلافـه فـى المسـتقبل ، فعصـا موسـى ئى صـارت حية ـ ثم قال القشيرى المقصود بذلك أن تكون للك آية ومعجزة لا بلاء ولا فتنة ('r). واسـتند النسـفى أيضــاً إلىى قولـه تعـالى :

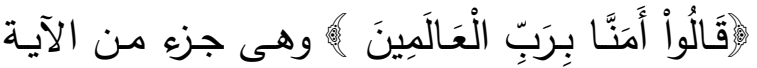

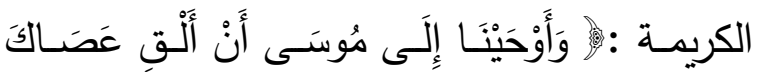

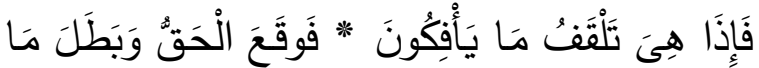

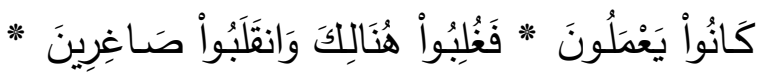

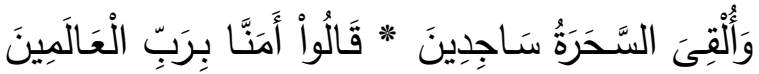

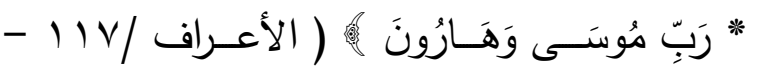

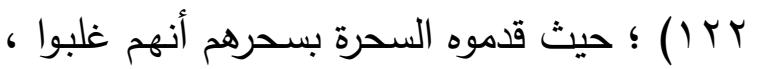
فأدخـل الله سـبحانه علـى تمويهـاتهم قهـر الحـق وطاشت تلك الحيل ، وخاب منهم الأمل ، وجذب الحق سبحانه أسرارهم على الوهلة ، فأصبحوا فى وهى وهل صدر العداوة ، وكانوا - فى التحقيق - من أهل الود ـ فسبحان من يُبرز العدو فى نعت الولى ، ثم يقلب الكتاب ويظهر الولى فى نعت العدو ، ثم يأبى الحال إلا حصول المقضى (rr).

فالسـحر بـالإطلاق صـفة مذمومــة وحظ الأولياء منها ما أطلعهم الله عليه من علم الحروف

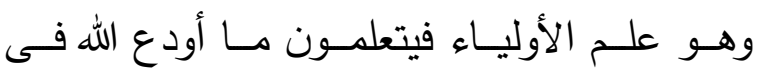

والعقـل الثانى موجـود فـى الموحـدين مفتـود مـن

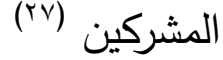

\section{ويواصل النسفى حديثه عن الطريق قائلاً :} " أيهـا الفقيـر ! " بضــدها تتبـين الأشـياء " إذا لـم يظهر نور الله ، فإنه لا يمكن معرفة ظلمة الدنيا . وكل من يبكى عليها ويتوقف على لذاتها وشهواتها

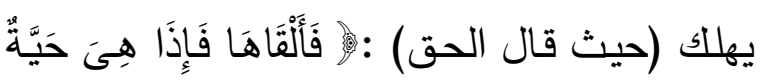

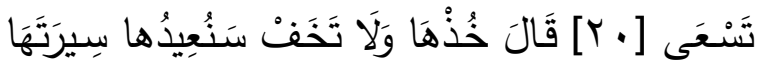

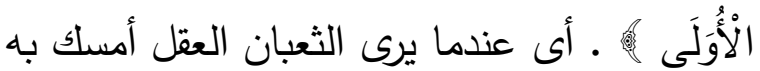
حينئذ ولا تخف ، فإننا نحل لعبـة العصسا ـ لكن مـادام للدنيا شـأن فإنـه يتعثر إلى الآن ، ومـادام السحر يمارس فى الدنيا إلى الآن فإنه يمنعلك عن إلى الهن الطريق ، ومادمت (لا) تطلب خدمتها فهى خادمة للك وتصبح مدداً ومعيناً للك فى طريق الله (حيث

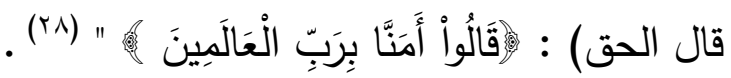

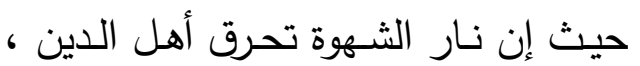
فنار الثـهوة تعنى الأهواء النفسية التى تنشأ عن إن الته النفس الأمارة ، يقول مولانا جلال الدين :

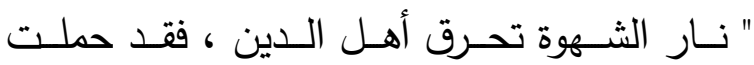
البستانيين حتى قاع الأرضنار الشهوة التى كانت

تشتعل ، خضرة التقوى أصبحت نور الهدى"(rar). كما أن نار العشق أيضًاً كناية عن لهيب العثق وثورته التى تحرق العشق دوما ، فيقول العطار : " نار عشقك أفضل فى الروح ، والقلب من عشقك أفضل باعثاً للنار 
مقابل العدم والشر "الظلمة " ، يقول ابن عربى : "

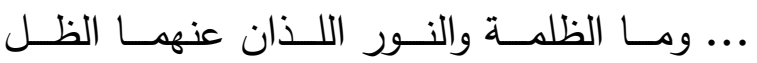
والضـياء؟ قلنـا : النـور كل وراد إلهى [ = نـور ] ينفر الكون [ = ظلمة ] عن الظلمة "(דr) . كمـال قـال الأخيـر فـى موضــع آخـر : " والروح: نور ، والطبيعة : ظلمة"(rv) .

ويواصل النسفى حديثه عن الطريق قائلاً:

" أيها الفقير ! إن الأخـلاق المحمودة جنـة واسعة

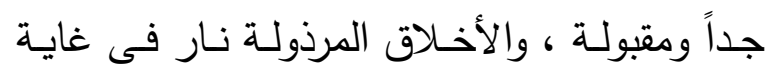
الضيق والقبح • ولذة الأخـاق المقبولة فى مقابلة لذة العلم والمعرفة وموازاتهما وهما كالقطرة والبحر

إن لذة الإدراك لذة فى غايـة الحسن ، كذلك فإن الشهوات الجسدية واللذات الجسمانية لا تصل إلى إلى لـذة الإدراك ـ بالنسـبة لجـواهر الأشـياء وحكمتهـا

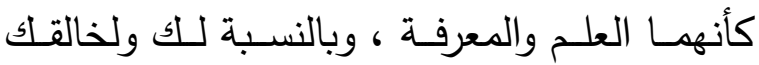

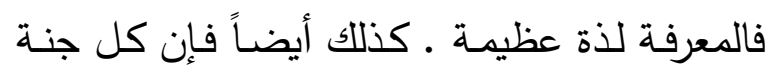
نهايتها أفضل ، وكل نار نهايتها أسوأ ، والمعرفة فى تلك الجنة تكون أكثر ، وعندما تكون المعرفة أكثر ، تكون تلك الجنة لهذا

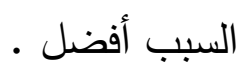

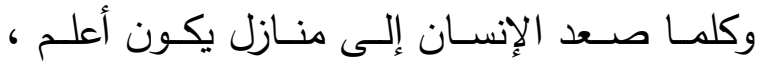
ويزداد تحقيقه وطلبه ، ويصعب عليه العمل أكثر. من هنا يكون أكثر خوفا من (الله) مَنْ يكون أكثر

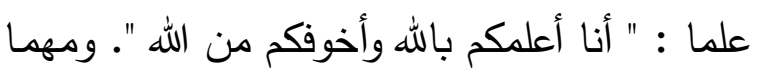
يكون أعلم، عليهه أن يحافظ على الظـاهر ، فـلا يقول شيئًا أو يفعله إلا بأدب أو حرمـة أو عزة ،
الحـروف والأســـاء مسن الخـواص العجيــة التـى تنفعل عنها الأشياء لهم فى عالم الحقيقة والخيال ، فهو وإن كـان مـذموماً بـالإطلاق فهـو محمـود التقييد ، وهو من باب الكرامات وخرق العادات(rr) • فقد كان سحرة موسى مـازال عنهم علم السحر مع كونهم آدنوا برب موسى وهارون ، ودخلوا فى دين الله وآثروا الآخرة على الدنيا ورضوا بعذاب الله على يد فرعون مع كونهم يعلمون السحر (ء). ويقول النسفى أيضاً : " أيها الفقير! العشق عصا موسى ، وعالم الساحر ، كل يوم (هو) فى سحر ، أى أنه يمارس الخيال كل يوم فينخدع الناس فى الدنيا بممارسة الخيال ، ويفتح العشق فيه على الدنيا ، ويبتلع كل ما فيها دفعـة واحـدة ـ ويجعـل السـالك طـاهراً وصـافياً ومجرداً • ومـن ثم يصـبح السـاللك اسـما للصـفاء مادام أنه لا يكون صسافياً ، وعندما يصبح صسافياً

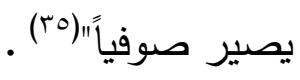

وبمـا أن الأشـياء تتبـين بضـدها، فإنـهـ لا يمكن معرفة ظلمـة الدنيا إلا إذا لم يظهر نور الله حيث إن النور يدرك ويدرك به ، والظلمة تدرك ولا يدرك بها ـ وقد يعظم النور بحيث أن يدرك ولا يدرك به ، ويلطف بحيث أن لا يدرك ويدرك به ، ولا يكون إدراك إلا بنور • سئل هل ؟ فقال : نور أنَّى أراه فنبَّه بهذا القول على غلى غاية القرب فإنه أقرب إلى الإنسان من حبل وريده . لعل النسفى هنـا متأثر بكـلام ابن عربى

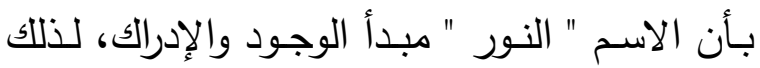
كل وجود أو خير فهو نور ، لأصله الإلهى فى الإنى 
تصفية العمل من كل شوب أى لا يمازج عمله مـا يشوبه من شوائب

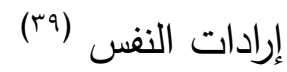

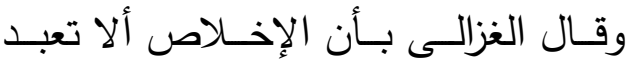

هـوالك ونفســك ، ولا تعبـد إلا ربــك وتسـتقيم فـى عبادته كما أمرت ، وهذا إشـارة إلى قطع ما سوى الله عن مجرى النظر وهو الإخلاص حقاً(•؛) .

ويؤكـد النسـفى علـى أن العـــم والمعرفـة

مقامان لهما لذتهما الحقيقية، فإذا عظمت المعرفة بالله - كما قال الجنيد - ذهبت آثار العبد وامَّحت

رسومه ، فعند

ذلك يبدو علم الحق ويثبت اسم حكم الله تعالى (اء)

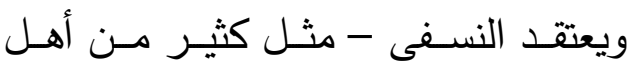

العرفان - بأن حواس الإنسان وقواه العقلية تعيش مع ظاهر العالم وماهياته وتعيناته ، ولكن الإنسان عن طريق الارتباط الباطنى والحضورى والتخلص مسن العلائق الظاهريـة والدنيويـة يسـطيع بحقيقـة الواحـد فـى العـالم أن يظهـر المبـادئ السـامية

وحقائق الأشياء من خلال المعرفة الثهودية والحضورية .

ويـرجح أهل العرفـان - مـع إقرارهم بقيمـة

العقـل واعتبـاره بالاسـتـدلال العقلـى والبرهـان المعرفة الناتجة عن المكاشفات والمشاهدات على النتـائج الحاصــلة مـن البـراهين العقليـة ، قـائلين بأصسالتها للمعرفة الثهودية والحضورية ـ وصرح الـبعض مـنهم بـأن العقـل لا يسـير إلـى حقـائق الأشــياء والمبـادئ السـامية ، والتمســك بالبرهـان
وعليـه أن يحافظ على الباطن حتى لا يفكر فى شـى إلا بـالأدب أو بحرمــة العـزة ؛ كلمـا اقترب أكثر ، عليه أن يزيد من المحافظة ، مادام لا يبلغ مكاناً عليه أن يكون مستعداً فيه دائماً ، وعليه ألا يكون غائباً للحظة ـ ولو غاب طرفة عين وقال كلمة ليست من سر الحضور يكون مأخوذاً وفى عتاب ـ ف " حسنات الأبرار سيئات المقربين " . هذا هو حضور أهل التصوف ، وهو مقام الخشية ، وهـو مقـام المحبـة ـ فالخشية والمحبـة قرينـان ، وكلاهما بعد علم ، وبسر النظر نفسـه قال بأن " المخلصون على خطر عظيم " • وكل صوفى لم يصل إلى هذا المقام لم يدرك عبقاً من التصوف ، وظن أن التصوف سجادة وتسبيح . أيها المسكين البعيد عن المقام ! إن دقام التصوف مقـام عـال ـ ألكيس للإنسـان احترام لذاتـه عندما يكون احترامه للسجادة والتسبيح ؟ " (^^)". لقد سار الصوفية على النهج القرآنى فى جعل القلب محل الكثف والإلهام - أداة المعرفة - وهـو المـرآة التـى تتجلى فيهـا معـانى الغيـب وتتـزل عليهـا الحكم . هـو باختصـار تلك القـوة الخفيـة التى تدرك الحقائق الإلهيـة إدراكاً واضـحاً جلياً لا يخالطه شك ـ فقد جعل الحق تعالى القلب فى القرآن هو العقل الذى يعقل عن الله كما ورد :

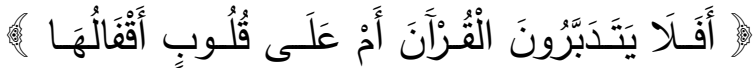

ويـرى النسـفى أن كل مـن لـم يبلـن درجـة

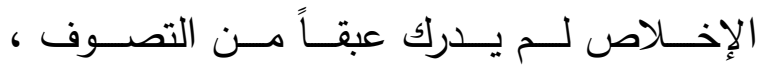
فالمخلصون على خطر عظيم ، ويعنى الإخلاص 
اتباع رضـا المحبوب ، وباطنها أن يكون مفتوناً بالحبيب عن كل شىء ولا يبقى فيه بقية لغيره ولا لنفسـه ، ويتفق مـع غيـره على أن حقيقـة المحبـة القلبية نار فى القلب تحرق ما سوى مراد المحبوب ـ فقد قيل : للمحبة ظاهر وباطن ، ظاهرها إتباع رضا المحبوب ، وباطنها أن يكون مفتوناً بالحبيب عـن كـل شـىى ، ولا يبقـى فيـهـ بقيـة لغيـره ولا لنفسه (₹v)

كما يؤكد شيخنا على السـاللك بألا يغيب

للحظة ، فلو غاب طرفة عين وقال كلمـة ليست مـن سـر الحضــور يكـون مـأخوذاً وفـى عتــاب

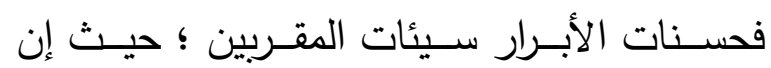
الحضور هو تتبه خاص يطرأ على قلب العبد إلى

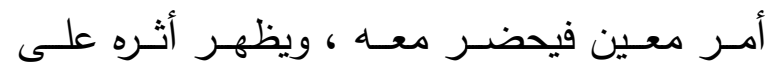
الجـوارح ، وفـى هـذه الحـال تفترض الغيبـة عدـا

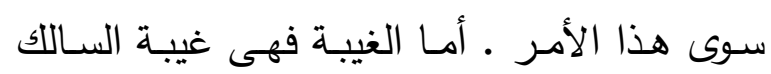
عن رسـوم العلم لقوة نـور الكشـف وصـورتها فىى هـ البدايات الغيبة عن رسوم العادات . فقــــ ورد فـى جــامع الأصــول أنــه فـى الأبواب : الغيبة عن النفس وأهوائها وعن صفاتها ودواعيهـا وآرائهـا ، وفى الأصــول : الغيبـة عـن القصد عما سوى المقصود وقصر الهمة فى السير على سمت الورد المورود ، وفى الأدوية : الغيبة

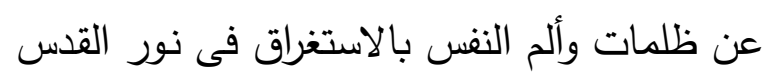
، وفى الأحـوال : الغيبـة عمـا يجـول بينـه وبـين المحبوب فى تباريق تجلى المطلوب ، ودرجتها فى الحقائق : الغيبة عن الأكوان والإمكان بشهود

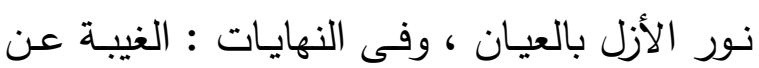

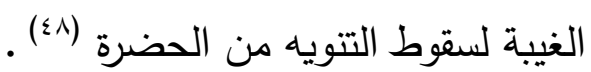

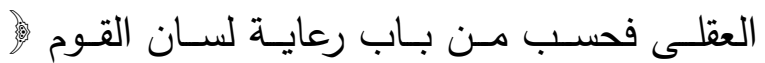

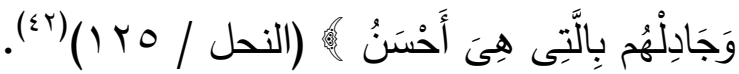
ويعتبر النسفى أن العلم والمعرفة كالقطرة والبحر حيث إن البحر كنايـة عن بحر الوجود ، والوجود المطلق ، ووحدة الوجود ، والبحر أيضـاً مقام الذات والصفات بلا نهاية للحق (r؟) ويؤكد شيخنا على أن من كثر علمه ازداد خوفه وخشيته من الله، فأصل الطاعة - كما قال حاتم الأصم - ثلاثة أشياء : الخوف والرجاء والحب ، وأصسل المعصسية ثلاثة أشياء : الكبر والحرص والحسد(ء)؛. أو كما قال الحارث المحاسبى : الذى يبعـث على التوبـة ترك الإصـرار ، والذى يبعـث على ترك الإصرار ملازمة الخوف (؛؛) . إذن التجربــة الصــوفية فــى مجاهـــاتها ورياضـاتها بين حدين الخوف والرجاء أى الخوف من الله ورجاء الله ، وهما مطلوبان لتكاملهما وليس لتقابلهما

يقول صـاحب اللمع ، الخوف على ثلاثة أوجـه : خوف العامـة وهـو اضطراب قلوبهم مدـا عملوا من سطوة معبودهم ، وخوف الأوساط وهو من القطيعة واعتراض الكدورة فى صفاء المعرفة ، وخوف أهل الخصوص وهم الخائفون من القطع

لـذا فـإن النسـفى يؤكـد علـى أن المحبـة

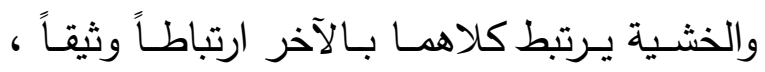
ويتفق على أن للمحبـة ظـاهراً وباطنـاً ، ظاهرهـا 


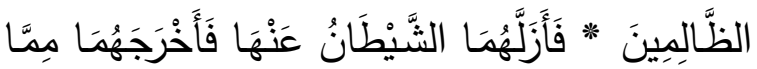

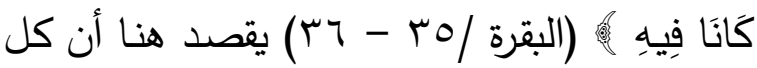
ما منع منه الإنسان توفرت دواعيه إلى الاقتراب منه ، فهذا آدم - عليه السلام - أبيحت له الجنة بجملتها ، ونهى عـن شـرة واحدة ، فليس فى

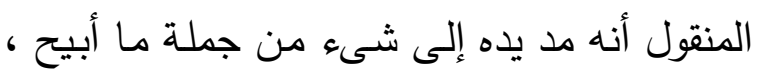
وكان عيل صبره حتى واقع ما نُهى عنه ، هكذا صفة الخلق •

هكـذا فـإن آدم - عليـهـ الســلام - بـاع

حضرة ربـه بلقهة ، يقول أبوزيد البسطامى : " لو لو لو

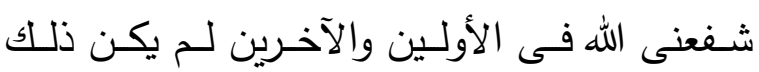

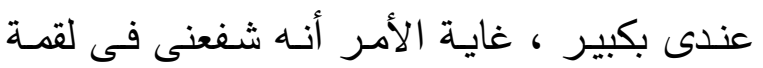
طين " (0.) بكين

ويؤكد على الآيـة الكريمة فـى أكثر من

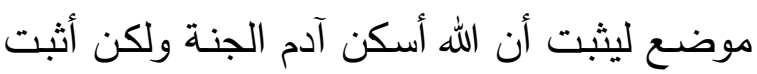

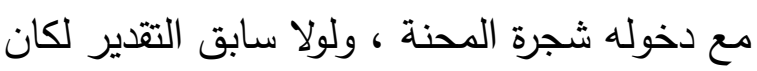
يبدل تلك الثجرة بالنضارة ذبولا ، وبالوجود فقداً ، وكانت لا تصل يد آدم إلى الأوراق ليخصفها على لئل نفسه ويقع منه ما يقع • ولو تطاولت تلك الثجرة

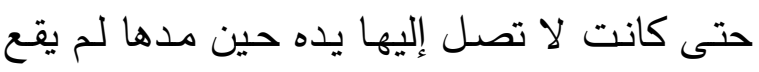
فى شأنه كل ذلك التشويش ولكن بدا من التقدير

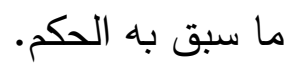

ويقول القشيرى فى تفسير الآية الكريمة :

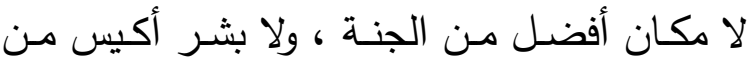

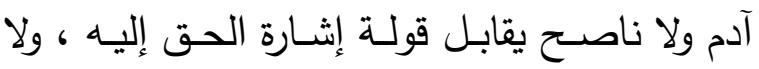

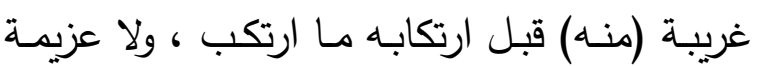

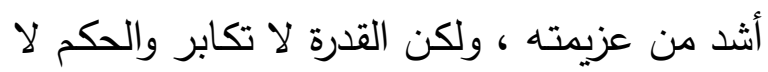

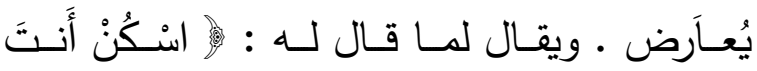

الفصـل الرابـع : الجنــان عنــل النسـفى وكيفيـة

\section{الوصول إليها - - اليها}

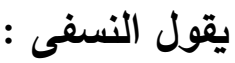

" اعلم أن النيران سبعة والجنان ثمانية ـ فلكل جنة

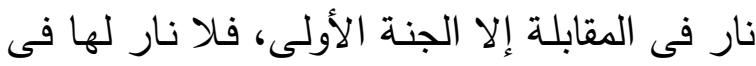

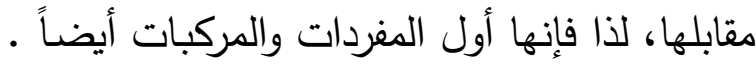
هكذا تكون مفردات كل واحدة موجودة لا ترقى لهما أو عروج ، ولا حس لهما ولا خبر ، ولا لهما

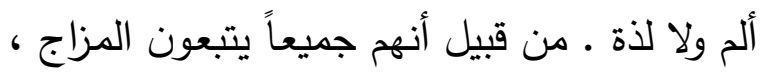

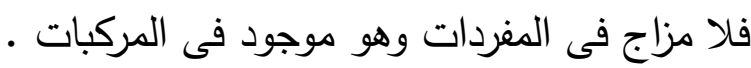
عندما لا يكون للجنة الأولى نار فى المقابلة يكون

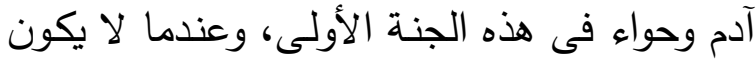

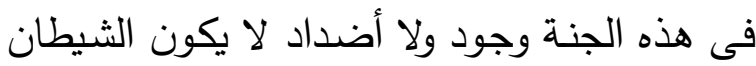

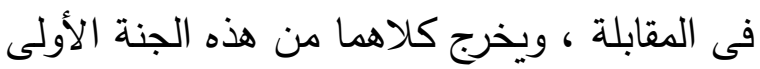
بخطاب (كن) ويبلغا من سماء العدم إلى عـالم

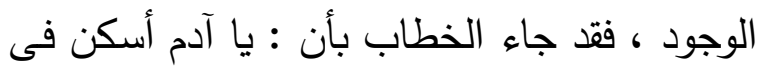

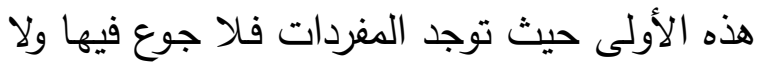
عطش ولا عراء ، ولا عناء فيها من القيظ أو البرد (\$9) "

أى عنــدما خلـق الحـق سـبحانه وتعـالى

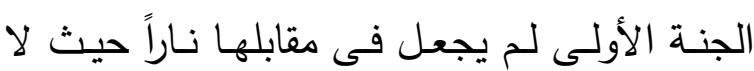
جوع فيها ولا عطش ولا عراء ولا عناء من القيظ أو البرد ، فخلق فيها آدم وحواء لييلغا من سماء

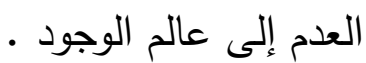

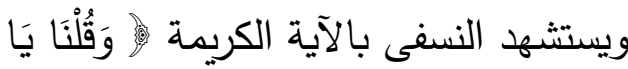

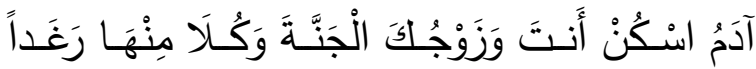

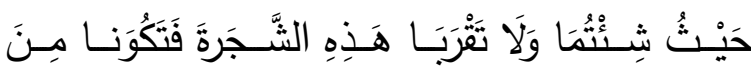


فثـجرة المـزاج - عنــــ النسـفى - قرينـة

الطرد من الجنة ، يقرب منها الإنسان من خلال

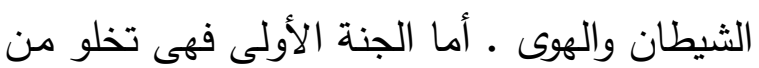

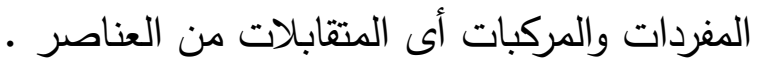

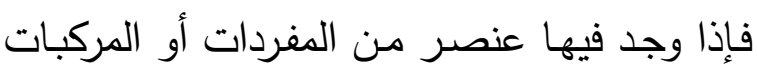

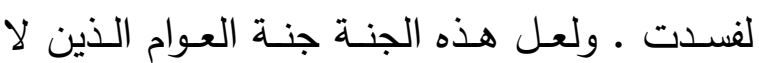

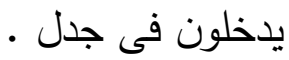

ويواصل النسفى شرحه للجنان فعن الجنة

$$
\text { الثانية والثالثة يقول : }
$$

" ولا تقرب شجرة المزاج ! فعندما تقربها ، لابد من الخروج من هذه الجنة الثانية . وعندما تخرج من هذه الجنة الأولى ، تصبح سىء

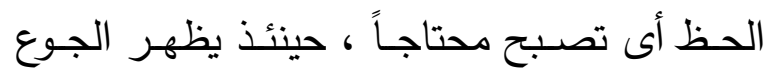

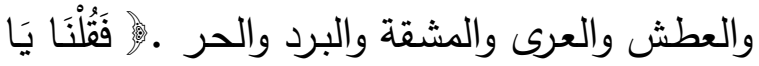

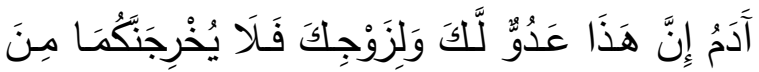

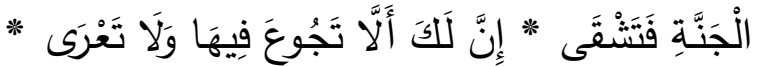

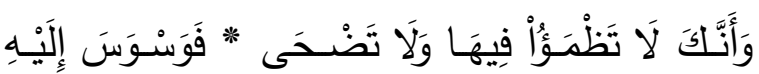

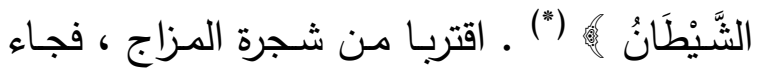

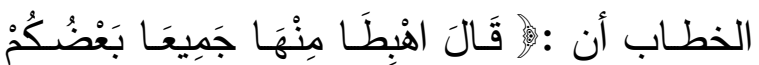
لِبَعْضِ ـ ـ فخرج الثَلاثة كلهم من الجنة الثانية ، ودخلوا الجنة الثالثة ، وبلغوا من سماء التثريد إلى لى لئه أرض التركيب، وأصبحوا فى هذه الجنة محتاجين

$$
\text { وجوعى وعطشى وعراة "(Or) . }
$$

يـرى النسـفى أن آدم - عليـهـ السـلام بوسوسة الشيطان له وإغوائه بأن يأكل من شجرة الهرة

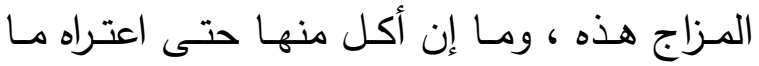
اعترى البشر بعد ذللك من جوع وعطش وعرى ومشقة البرد والحر ، وهو يدعو السالك هنا لعدم

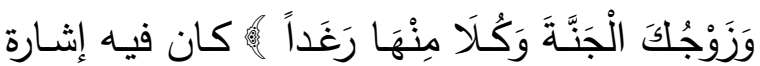
إلى أن الذى يليق بالخلق السكون إلى الخلق ، والقيام باستجلاب الحظ ، وآدم - عليه السـلام وحده كان بكل خير وكل عافية ، فلما جاء الثكل

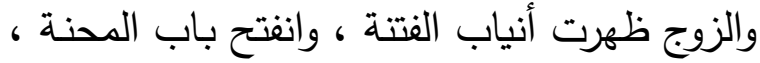

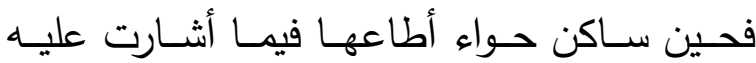
بالأكل ، فوقع فيما وقع (1) لقد نبَّه الحق سبحانه على عاقبة دخول آدم الجنة من ارتكابه ما يوجب خروجه منها حين

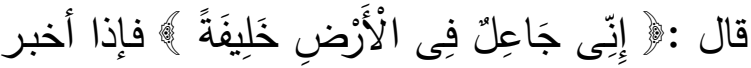

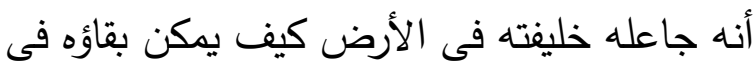
الجنــة ؟ويقـال : أصـــح آدم - عليـهـ الســلام محمود الملائكة ، مسجود الكافة ، على رأسه تاج التهاج الوصلة ، وعلى وسطه نطاق القربة ، وفى جيده

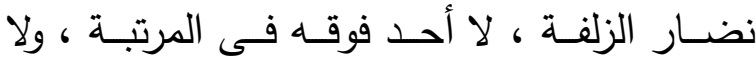
شخص مثله فى الرفعة ، يتوالى عليه النداء فى آلى لآل

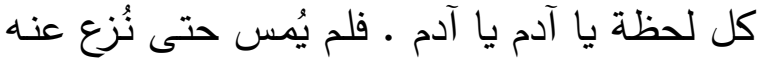

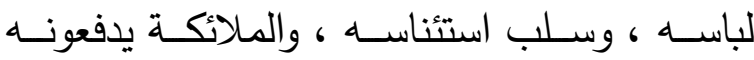

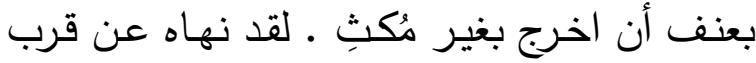
الشجرة بأمره ، وألقاه فيما نهاه عنه بقهره ، ولنَّس

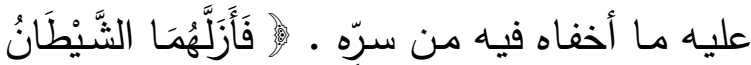

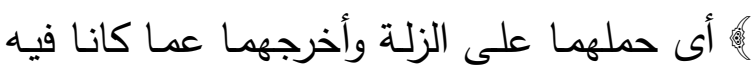

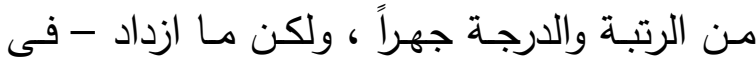

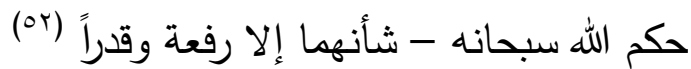
ويذكر النسفى بأنسه توجد فى بدايـة كل

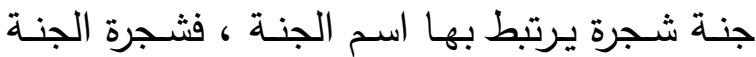

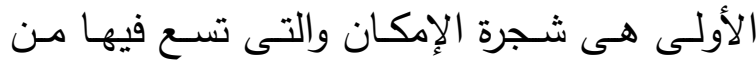

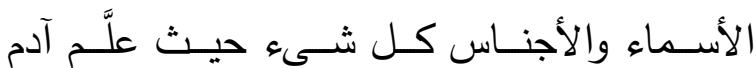
الأسماء كلها . الأسعاء والاء 
طاعة الله يبعد الناس عن طاعة الله فهو الشيطان

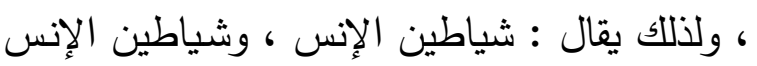

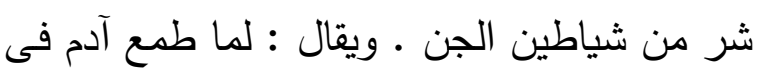

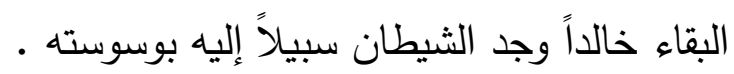
والنـاس تكلموا فـى الثـجرة : مـا كانت ؟

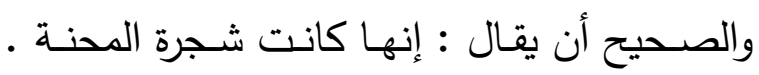
ويقال لو لم تخلق فى الجنة تلك الشجرة لما كان

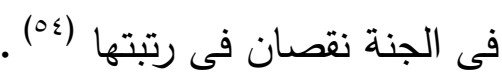

ويواصل النسفى شرحه للجنة الثالثة قائلاً : " ... والجنـة الثالثة هذه جنـة البلهاء والأطفال .

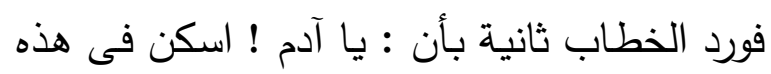
الجنة الثالثة ! حيث فيها نعم كثيرة ، ولا تحريم عليك فيها أو لوم أو حجة ـ فكل ما تريده ، ومن

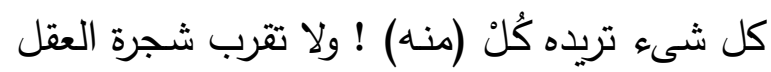

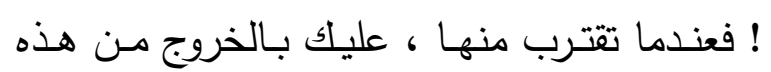

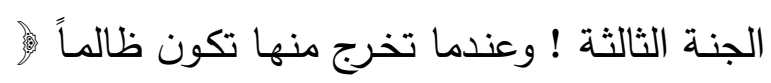

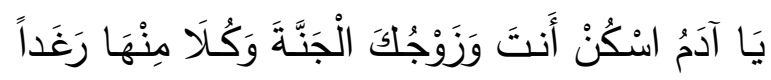

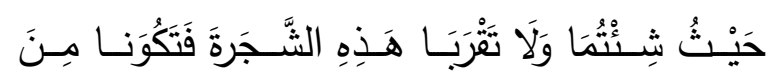

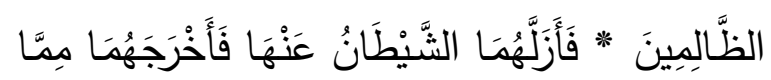

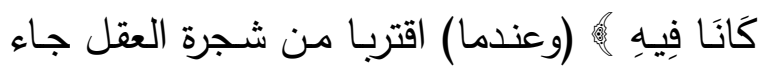

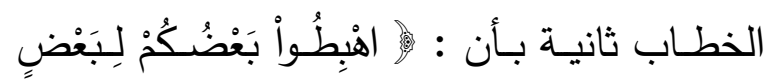

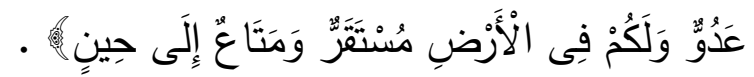

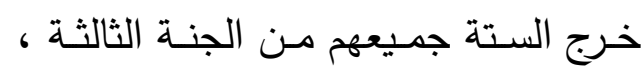
ودخلوا الجنة الرابعة . أيهـا الفقير ! خـرج الثلاثتة مـن الجنـة الثانيـة آدم

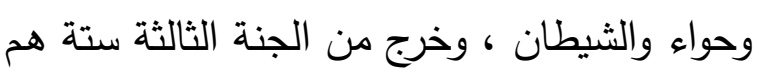
آدم وحواء والثيطان وإبليس والطاووس والثعبان .

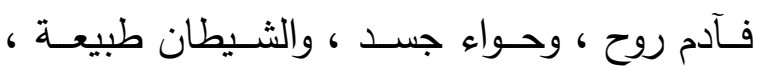

الامتثال لأواهـر الثـيطان واغوائه حتى لا يلقى الثقاء الأبدى ـ فاستشهــ بالآية الكريمة السـابقة

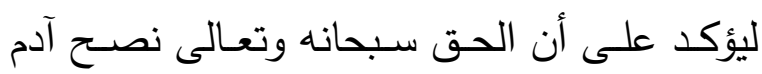
وحواء بعد القرب من هذه الثجرة التى ظناً أنها

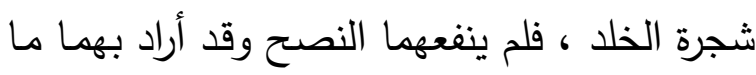
حذرهم ، وعلم أنهم سيلقون ما خوفهم به ، فقوله

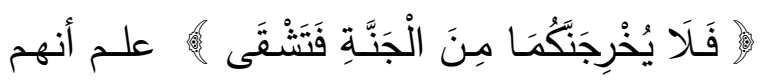
سيلقون ذلك الثقاء .

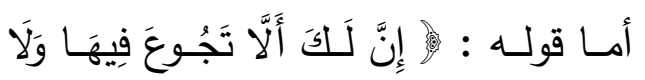

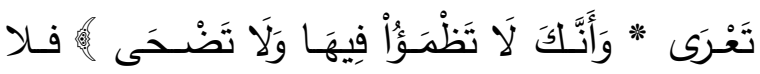
تصديق أتم من تصديق آدم ، ولا وعظ أشد رحمة

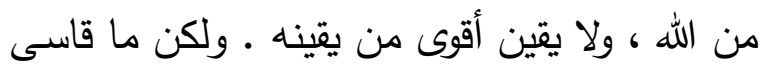

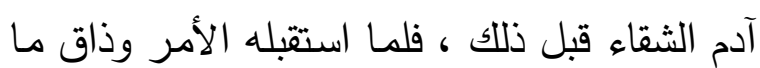

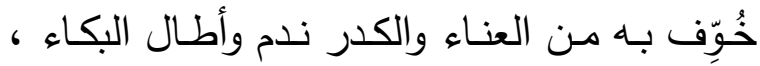

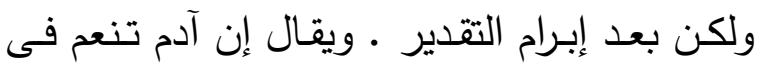
الجنة ، ولم يعرف قدر ذلك إلى حين استولى -

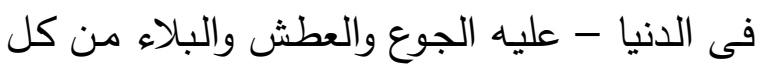
نوع وفن • وكان آدم إذا تجدد لـه نوع من البلاء

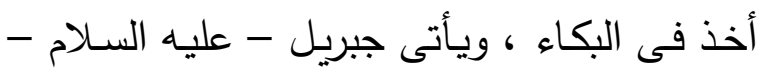
ويقول : " ربك يقرئك السلام ويقول : لم تبكى ؟

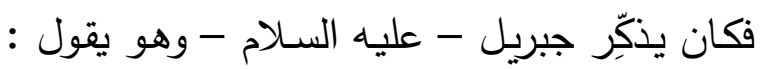

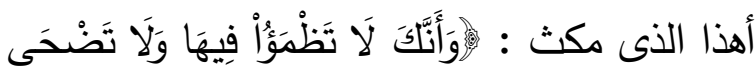

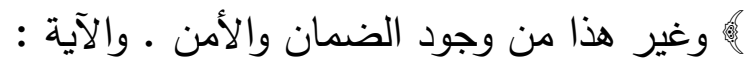

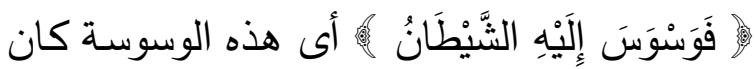
الحق يعلم ذلك ولم يذكر آدم فى الحال أن هذا

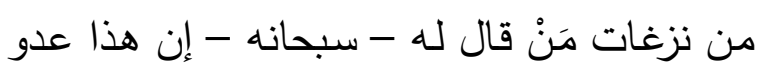
. لك ويقول القشيرى : يقال ، سـى الشيطان

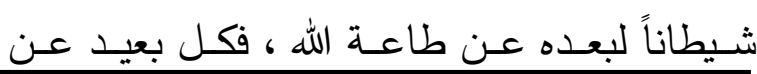


صحبته شهوته " (40) . بينما يفسر أبوحاتم الأصم

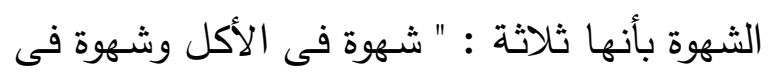

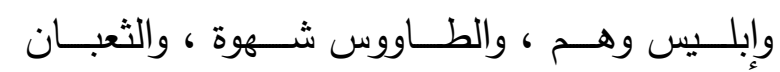
الكـلام وشـهوة فـى النظـر ، فـاحفظ الأكل بالثقــة

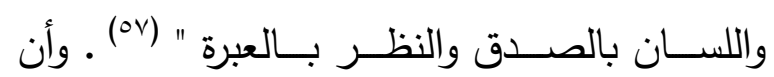
يتجنب السالك الغضب ، فهو من المهكات التى لـ لـ

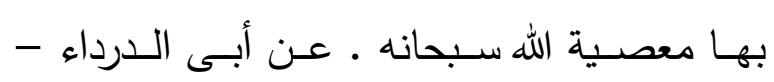
رضـى الله عنه- أنه قال للنبى عمل يـدخلنى الجنـة ـ قـال : لا تغضـب " (01) .

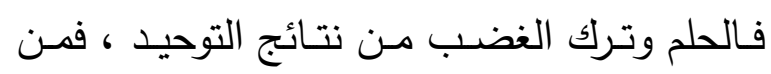
غلب عليه التوحيد حتى يرى الأشياء كلها من الله تعالى فإنه لا يغضب على أحد من خلقه إذ يراهم مسخرين فى قبضـة قدرته فيندفع الغضب والغيظ بغلبة التوحيد ، ويندفع أيضاً بحسن الظن بالله وأن

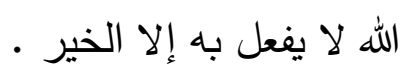

أيضـاً على السـالك أن يجاهـد الشـيطان

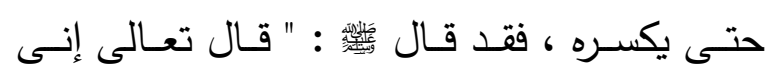

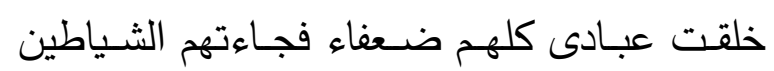

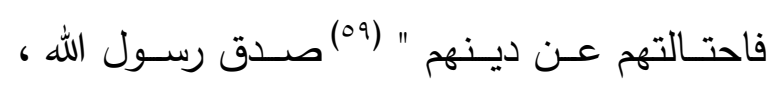

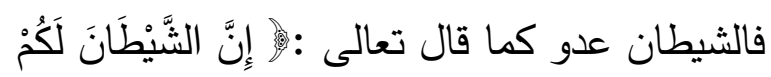

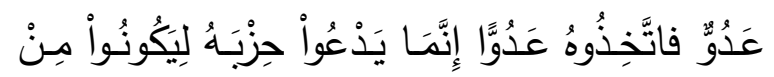

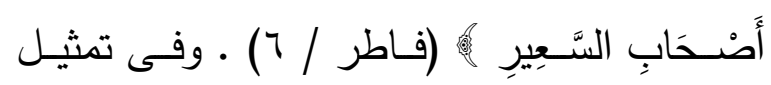
النسفى للشيطان بالطبيعة لأنه مركب من عناصر عدة، تؤدى بالعبد إلى الضلال . ويؤكد فريد الدين العطار على أن العقل كامـل فـى معرفـة الحـق بـلـ الأكمـل منـه الـروح والقلب قائلاً :

ويرسم لنا النسفى الطريق إلى الجنة بأن

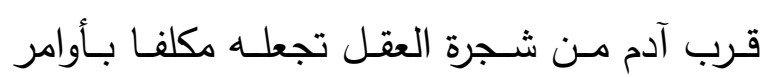
الثريعة ونواهيها فتخرجه من الجنة الثالثة التى لا لأنه

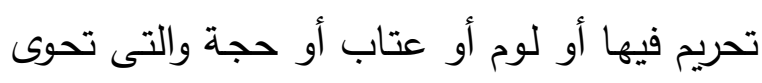

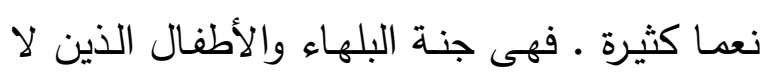
تكليف عليهم .

ويستند النسفى فى قربهما من شجرة العقل

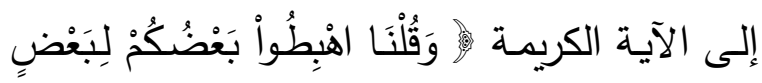

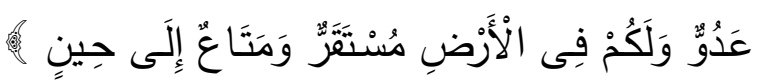

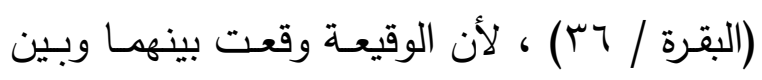
الشـيطان ،ـ ولكن الله سبحانه كان مـع آدم ـ فلو كان لإبليس سلطان على غوايسة غيره لكان لـه إمكان فى هداية نفسه حيث إن التفرد بالإبداع لكل شىء من خصائص نعته سبحانه وتعالى .

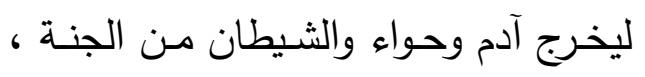

ثم يخرج الثلاثة مـن الجنـة الثالثة ومعهم إبليس والطاووس والثعبان ل

ويمثل النسفى لإبليس بالوهم، والطاووس بالثـهوة ، والثعبـان بالغضـب ، فعلى السـاللك أن لأن يبعد عن الوهم فهو صففة النفس وحجاب العقل بل بابل بال وغمامسة شمس القلب ، فبإذا ارتفع حجاب الأوهام شـهدت أنـوار حضـرة الإلهام ، والوهم يثبت إنَّيـة العبد مـع الحق ويخيفه مـن الناس ، ويوقعسه فى اليأس ، وعليـه أيضـاً أن يبعد عـن الثـهوة ففيهـا

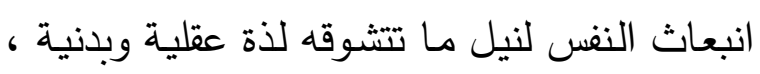
فقد قال أبويزيد البسطامى : " لا يعرف نفسـه من 
فكن فى سعى وكد ، ولا تقض وقتاً فى طريق ، حينئذ تصل إلى نور الله " (rآ)

ويؤكــــ النسـفى على أن السـاللك ببلوغـه

شجرة العقل يبدأ التكليف والأمر والنهى بالنسبة له والذى هو صلب الشريعة ، فالتكاليف شاقة على العبـاد ويـدخل امتثـال الأوامـر والانكفــاف عـن الزواجر والصبر على الأحكام والشكر عند وجود النعم ، فهى إذن أربعـة : طاعـة ومعصية ونعمـة وبلية ولكل منها عبودية يقتضيها من العبد بحكم الربوبية ، فحقه عليك فى الطاعة شهود المنـة منـه عليك فيها ، وحقه عليك فى المعصية الاستغفار مما صنعت فيها ، وحقه عليك فى البلية الصبر معهه عليها ، وحقه عليك فى النعمة وجود الشكر منك فيها منكا

ويواصـل المؤلف بـث إرشـاداته ووصـاياه

للسـالك حتى يبــن لقـاء الله ومعرفـة صـفاته بعـد إتمامه للمجاهدات والرياضات ، فيقول النسفى : " أيها الفتير ! مـادام السالك لا يشرف بلقاء الله ، فإنها لا يعلم الثـى البته كما هو ، ولا يراه ـ فلا شـأن للسـاللك أكثر مـن أن يعـرف الحـق ويـراه ، ويعلم صفات الله ويراهـا ـ كل من لا يرى الله ولا يعرف صفاته ، فقد جاء أعمى ومضـى أعمى . عندما وصل السـاللك إلى نور الله وأتم الرياضـات والمجاهدات باقتدار ، ووصل إلى ذلك المقام فإن الله يقول " كنت له سمعاً وبصراً ويداً ولسـاناً ، بـه يسمع وبه يبصر وبه يبطش وبه ينطق " . وبلـغ

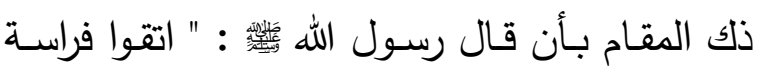

" العقل كامل فى معرفة الحق ، لكن الأكمل منه الروح والقلب لو يلزمك كمال العشق ، بغير القلب لا يتكشف للك هذا الحجاب " (.7)

\section{وينتقل المؤلف إلى الجنة الرابعة قائلاً :}

" وعندما اقترب آدم من شجرة العقل ، خرج من الجنـة الثالثة ، ودخل في الجنة الرابعة ، فسجدت الملائكة جميعـاً لآدم إلا إبليس لـم يسـد وأبسى . أى إن كـل القـوى الروحانيــة والجســـانية كانـــ

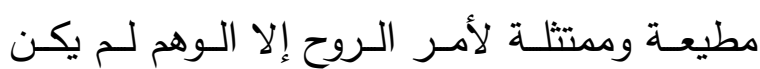

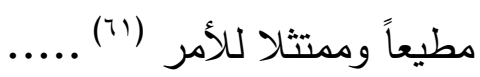
أيها الفقير ! كلما يصـعد الإنسـان إلى المنـازل ، يكون أعلم ويصبح أكثر استعداداً ، ويشق الأمر عليه . ومن هنا جاء الخطاب لآدم فى البداية بأن يا آدم اسكن فى هذه الجنة الثانية ولا تقرب شجرة المـزاج ، فمهمـا تترقى إلى منــازل ، يكـون الأمـر

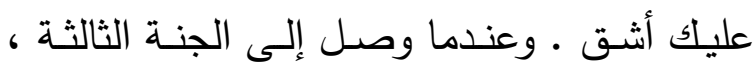
جاء الخطاب ثانيـة بأن يـا آدم ! اسكن فى هذه الجنــة الثالثـة ، ولا تقـرب شـجرة العقـل ـ عنـــــا

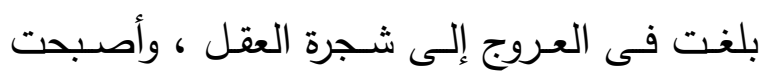

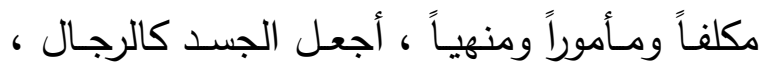
وضع قدماً فى الطريق ، فالبقاء فى الطريق ليس من عمل الرجال ومرٌّ على هذه النيران والجنان ، ولا تلتفت إلى خير قطولا تجبر على شىء قط ، ولا تهرب من شر ، ولا تتأخر عن الطريق، فإن هذا الخير والشر من أجل ذلك ، مادمت تتربى

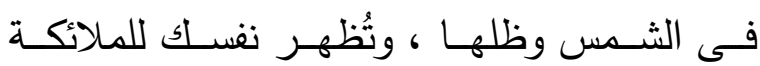
فأجبتُ عليهم بأنك لا تعرف شيئاً هم لا يعرفونه ، 
فـالنور هو مفتـاح أكثر المعـارف ، فمن

ظن أن الكثف موقوف على الأدلة المعجزة فقد ضـيَّق ، رحمـة الله واسـعة ـ ولمــا سـئل رسـول الله

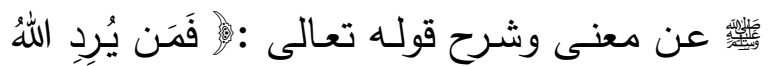

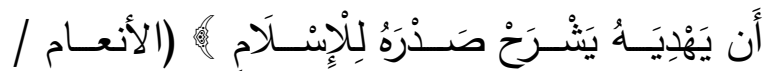
0 ا ( ) ، قال : هو نور يقذفه الله تعالى فى القلب ، فقيـل : ومـا علامته؟ فقـال : التجافى عن دار الغرور والإنابة إلى دار الخلود "(70")

وقد ورد - عنـد الغزالـى - بمسـند أحمـد

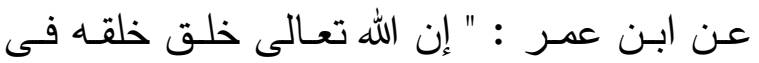
ظلمـة ، فألقى عليهم من نوره ـ فمن أصـابه من ذلك النور يؤمئذ اهتدى ومن أخطأه ضل " ، فمن ذلك النور ينبخى أن يطلب الكثف ، وذلك النور

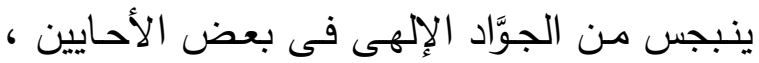
ويجب الترصد له (ז').

وقد جـع النسـفى فـى الفقرة السـابقة بين المشـاهدة والرؤية ، فالمشـاهدة رؤية فى الأصل ، إلا أنها رؤية يسبقها علم بالمرئى ، لذلك يحكمها الإقرار والنفى على حين أن الرؤية لا إنكار فيها. وهذا مـا يؤكد كـلام ابـن عربـى فـى أن

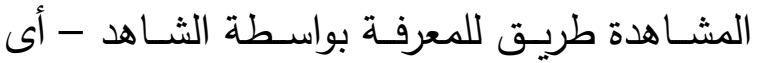
صورة المشهد التى تبقى فى النفس بعد المشاهدة،

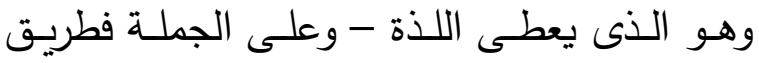
المعرفـة بالله على ثلاثة أقسـام : المعرفة بالدليل والمعرفـة بالثــهود والمعرفـة بـالإعلام ، وأعلاهـا الإعلام ، يقول ابن عربى :" ... فالتلث : الواحد من العلم بالله هو ما يعلم من الله بالدليل ، والثلث

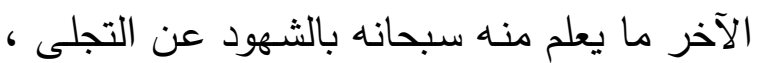

عندما بلغ السالك نور الله ، فهو الآن سالك لنور الله ، ومــادام سـالكاً لنـور العقـل إلـى الآن ، فقــــ انتهى أمر العقل ، ولا يزال سالكاً لنور الله ـ كلما يفيض نور الله فإن كل الحجب النورانية والظلمانية تتكشف أمام السالك فيرى الله ويعرفه ـ أى أن نور الله يبــنغ بحـر النــور ، ويـراه ، وبعـدها يكـون مصاحباً لنوره فيقدر على رؤية نوره ويستطيع معرفته " (rآ) . ويجب على المريد ألا يقف فى الطريتق بل يجب عليـهـ أن يتدرج بين الأحوال والمقامـات على الرغم من كونـه شـاقاً ، فعندما يثبت الحسال عنده يكـون مقامـاً ـ لـذا فـإن النسفى يطلب مـن السـالك أن يكـون رجـلا فـى الطريـق إلى الله لعلـه يرى نوراً من صفات الله - عز وجل . ويواصل النسفى حديثه عن نتيجة وصول الساللك إلى الجنة قائلاً : " مادام الساللك لا يصل إلى نور الله فإنه لا يصل إلى المشاهدة ـ يقول فى ذلك: رفيق نورك من يعرف أنه يراك إذ لا يمكن أن يراك نور البصر هذا " .. وعندما وصلت عرفت نفسـك وعرفتتى وتشـرفت بلقائى، وعندما تشرفت بلقائى ووصلت إلى الجنة الحقيقيـة واكتملت معرفتلك تجدنى وتحصل على كلا العالمين وتعلم كل شـى (فيهما) ـ كذللك لا يخفى عليك شىء فى الملك والملكوت والجبروت . فالجنة هى الجنة ، واللذة هى اللذة"(๕؟) . 
أيها الفقير ! مـادام السـالك لا يعبر من مجموعة الحجب الظلمانيـة والنورانيـة هذه ، ولا يخرج من

الخيال والظن لا يستطيع المجيء ، وعندما يخرج من الخيال والظن وعلم اليقين ويراها ظاهرة وأنها جميعاً كانت مشكاة ، يصل إلى ذات الله . وعندما يبلغ ذات الله ، ويؤثر وجوده فإن الله تعالى يبدل وجود الساللك ـ فكل ما يقوله ويفعله السالك يقوله بقول الحق سبحانه وفعله ، ليصبح السالك عالماً وقادراً ، ويصبح صاحب قدرة وصاحب همة

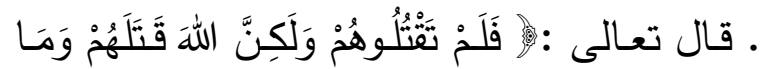

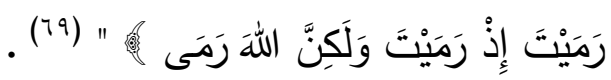

يـرى النسـفى - مثنل غيـره - أن الحجب

الظلمانيـة والنورانيـة والخيـال والظـن تمنـع السـالك من الوصول إلى ذات الله ، فالحجاب باب وطريق موصل للمحجوب بـه ـ أى هو الفاصل الموصل

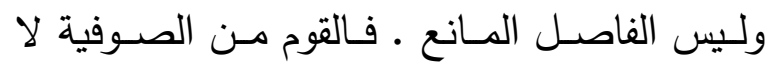
يسعون إلا الوجـه الإلهى ، فهو مطلوبهم فيكون الحجاب كل مـا يقف فى طريق رؤيتهم المباشرة

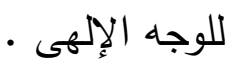

والحجبـ ليســت بمكانـة واحـدة بـل فيهـا

حجب دنيـا وحجب عليـا ، فالحجب الـنيا مثل حجاب النفس والطبع والثـهوات ، والحجب العليا هى التعينات والعلم والمحبة .

ولم يخرج النسفى على أن الحجاب الذى يحتجب بـ الإنسان عن قرب الله إما نورانى وهو نور الروح ، وإما ظلمانى وهو ظلمة الجسد ـ ففى إدى الحجاب ذل كما قال سرئٌ السقطى : اللهم مهما عذبتنى بشىء فلا تعذبنى بذل الحجاب(v) .
والتثلث الثالث هو مـا يعلم منـه بإعلامـه سبحانه وهو أصح الأقسام فى العلم بالله " (TV) .

إذن النور سبب الكثف والظهور إذ لولا النور ما أدرك البصر شيئًاً .

ويــرى النسـفىى أن معرفــة الســالك إذا

اكتملـت أى عـرف نفسـه وعـرف الحـق سـبحانه سيشرف بلقاء الله سبحانه ، ويبلـن الجنـة الحقيقية

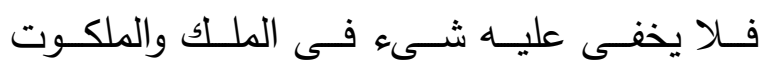
والجبروت ـ لأن المعرفة على ثلاثة أوجها - كما ورد فى اللمـع - معرفـة إقرار ، ومعرفـة حقيقـة ، ومعرفـة مشـاهدة ، وفى معرفـة المشـاهدة ينـدرج

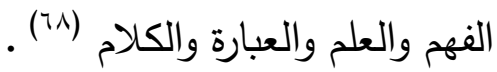

وينتقل النسفى فجأة فى رسالته من الجنة

الرابعـة إلىى الجنـة الثامنـة دون تصـريح أو تلمـيح للجنان الثلاث الأخرى ، فيقول :

" أيها الفقير ! هذه الجنة الثامنة ، وهى عند هذا الضـعيف أنها الجنـة الأخيرة ، وليس هنـاك جنـة النها أخرى غير هذه الجنان الثمان ـ لكن البعض يقول

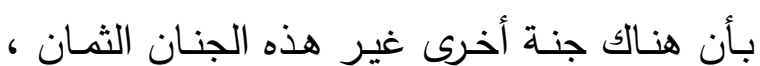
وفى تلك الجنة شجرة اسمها شجرة القدرة . عندما يصل السالك إلى نور الله ، ويتشرف بلقائه يصل إلى عين اليقين • أى أنه إلى الآن كان يعلم بعلم اليقين ، ويـرى الآن وجـود الله مباشـرة بعين

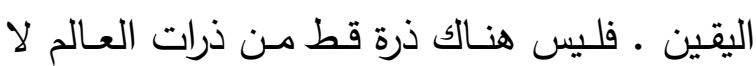
يوجد نور الله عليها بنفسه ، ولا يكون محيطاً بها

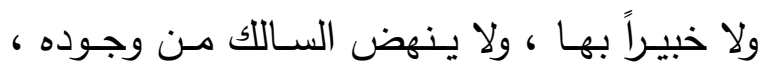
ويؤثر الوجود ويخرج من الغرور والظن . 
سبحانه ، والذى يوصف بـه الخلق من القتل هو مـا يفعلونـه فى أنفسـهم ، ويحصـل ذهـاب الـروح عقبـه ـ وفائدة الآيـة قطـع دعـاواهم فى قول كل

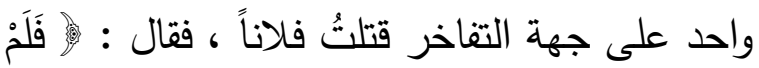
تَتْتُلُوهُمْ هُه أى لم تكن أفعالكم مما انغردتم بإيجادها بل المنشىء والمبدئ و الله - عز وجل - وصنهم بهذه الآية - عليه السلام - عن ملاحظة أفعالهم وأحوالهم الاهـ

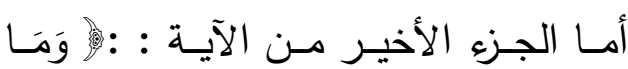

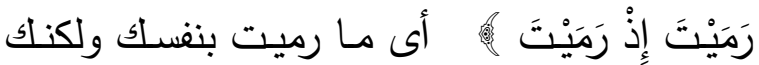

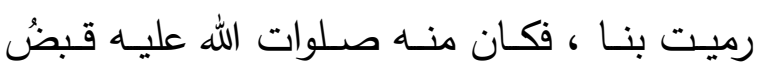
التراب وإرساله من يده ولكن من حيث الكسب ،

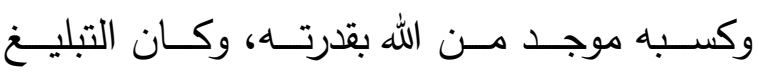
والإصـابة من قبل الله خلقاً وإبداعاً ، وليس الذَى مولى أثبت ما نفى ولا نفى ما أثبت إلا هو، والفعل فعل واحد ولكن التغاير فى جهة الفعل لا فى عينه .

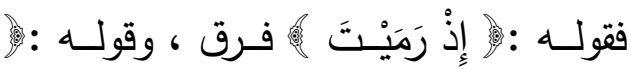

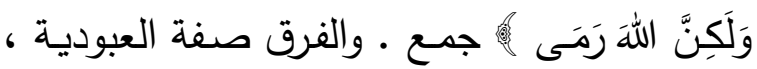
والجمع نعت الربوبية ، وكل فرق ، لـ يكن مضمناً بجمع وكل جمـع لـم يكن - فـى صـفة العبد مؤيَّاّ بفرق فصاحبه غير سديد الوتيرة • وإن الحق سبحانه يكلُ الأغيار إلى ظنونهم ، فيتيهون فى لهي أوديـة الحسبان ، ويتوهمون أنهم منفردون بإجراءٍ ما منهم ، وذللك منه مكر بهم (Vr) .

وقـــ أورد النسـفى جنــة تاسـعة تحكيهـا

جماعة ، لم ير شيئًا فى مثيلاتها ، فيقول :

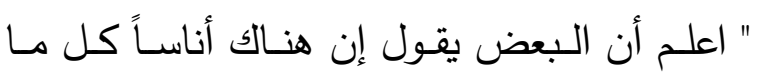
يريدونه يمنحه الله (لهم)، وكل شىء يلزمهم يصبح
ويـرى النسفى أن اليقين هـو المشـاهدة ،

ويتم ذلك بالإيمان والعقل والمعرفة وحسن التدبير

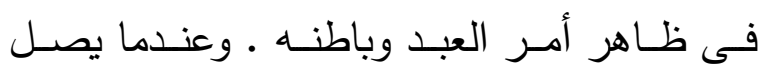
السـالك إلـى نـور الله ويتشـرف بلقائهه يصـل إلى عين اليقين، فيرى وجود الله مباشرة . ويؤكد النسـفى على أن السـالك بخروجـه مـن الحجب الظلمانيـة والنورانيـة والخيـال والظـن وعلـم اليقـين ، يسـتطيع أن يصـل إلـى ذات الله بحيث أن ما يقوم به أو يفعله أو يقوله يكون بالله

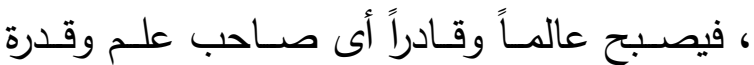

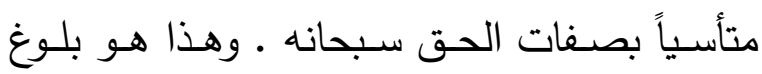
الجنة الثامنة عنده . - الجن

ولعل المؤلف يقصد بوصـول السـالك إلى

ذات الله إدراك صــفات الله، لأن ذات الله لا تـدرك بمفهوم عبارة ولا تفهم بمعلوم إشـارة ، لأن الثىء إنما يفهم بما يناسبه فيطابقه أو بما ينافيه فيضـاده ، وليس لذاتـه في الوجـود مناسب ولا مطابق ولا مناف ولا مضـاد (I') . وهذا قريب من كلام نجم الدين دايه : " لا يمكن أن يدرك العقل كنه ذات الحـق وصـفاته ، فـالحق منـزه عـن عقـل العقـلاء وفهم الحكماء ، بل يجب أن ندرك ذاته به هو كما قال ذوالنـون : " عرفت ربى بربى ، ولولا فضـل ربى ما عرفت ربى" (Vr) .

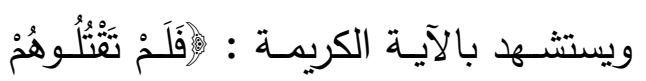

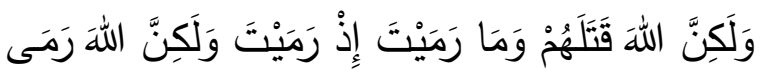

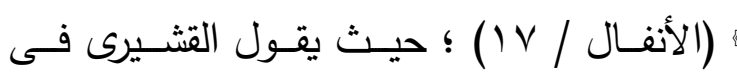
تفسير الآية ، الذى نفى عنهم من القتل هو إماتة الروح وإثبات الموت ، وهو من خصـائص قدرته 
بعهد التوبـة ـ وفى الأبواب تعلق القلب بالنعيم

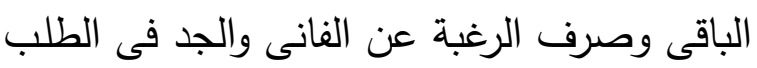

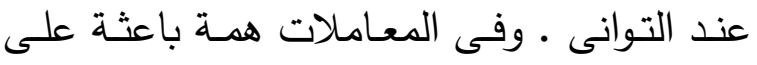

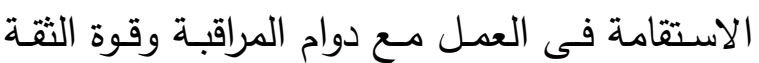
بالله فى التوكل والتسليم • وفى الأخلاق صرف

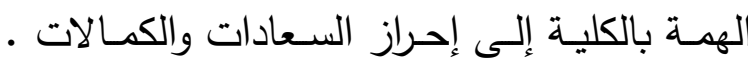

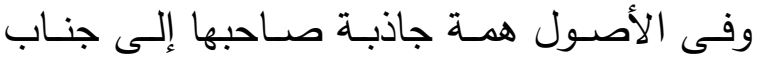
الحق بقوة اليقين وروح الأنس مانعـة عن الفتور فى السير والزيخ فى القصد ، ودرجتها فى الأحوال

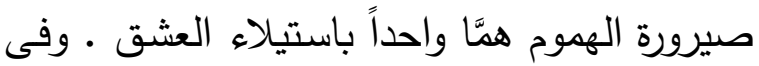

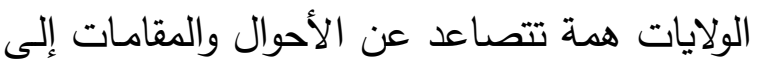

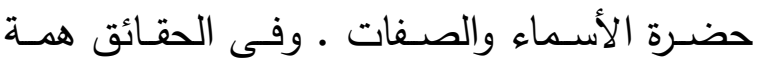
تعلو الصفات وتتحو عن النعوت نحو الذات .

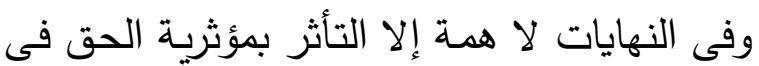
جميع الممكنات " (vo) . لعل النسفى هنا يقصد بالهمة، همة أرباب

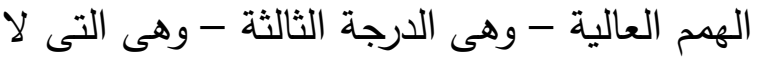
تتعلق إلا بالحق ولا تلتفت إلى غيره ، فهى أعلى التى

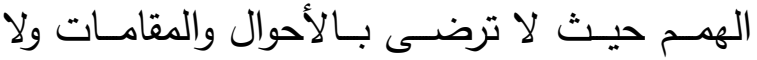
بالوقوف مع الأسماء والصفات ولا تقصد إلا عين

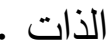

هنـا يكـون السـاللك صـاحب هــة وقدرة

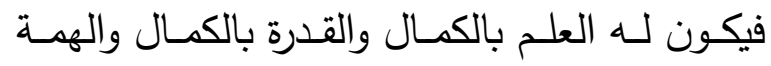
بالكمال ، وتحصل كل مراداته وكل ما يريده يجده

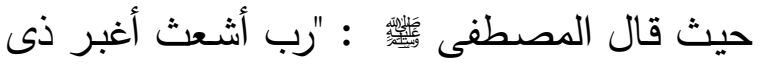
طهرين تتبو عنه أعين الناس لو أقسم على الله

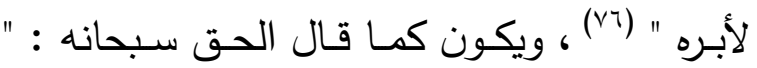

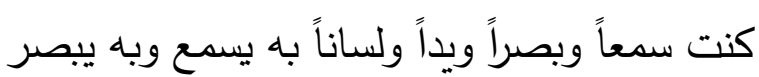
وبه يبطش وبه ينطق" (vV)
هو ، ويعقدون الهمة فى كل شىء فيصبح كذلك حيث تكون همتهم " رب أشعث أغبر ذى طمرين

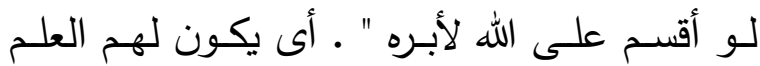

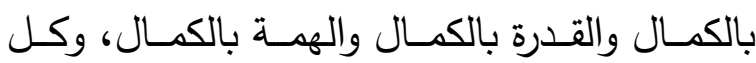
مراداتهم حاصلة وكل شىء يريدونه يكون هكذا .

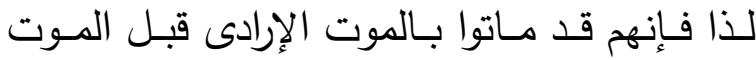
الطبيعى ، وعبروا من الدنيا وهم فى الآخرة . على سبيل المثال لو أرادت هذه الجماعة أن ينزل مطر ، ففى اللحظة التى تمر فى خاطرهم يظهر

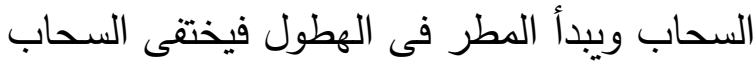

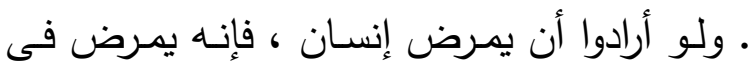
الحال ، ولو أرادوا أن يتعافى مريض يدرك العافية

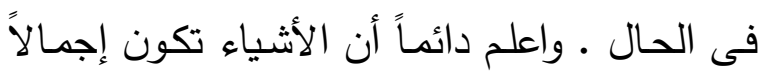

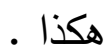

ويقال أيضاً : إن هذه الجماعة تذهب من المشرق

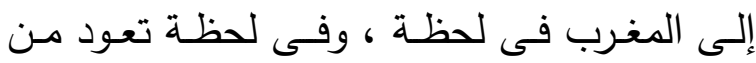
المغرب إلى المشرق ـ ولو أرادوا السير على الماء ولو أرادوا أن يحلقوا فى الهواء ولو أرادوا المشى • ولى الهي

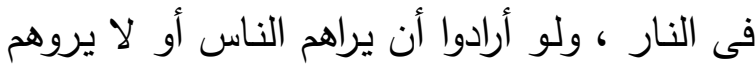
(لفعلوا) ، ويصل إليهم رزقهم يومياً جاهزاً ومعداً

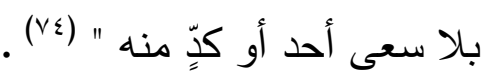

هنا يؤكد النسفى على هــة السـالك كلية

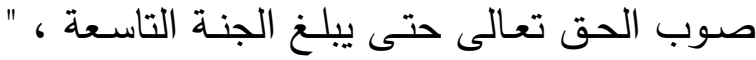

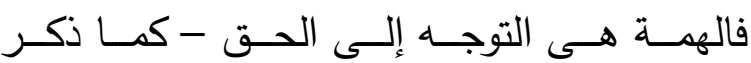
الكمشـخانوى - بالكليـة مـع الأنفـة مـن المبـالاة

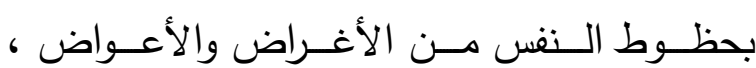
وبالأسباب والوسائط كالعمل والأمل والوثوق بها . وصورتها فى البدايات عقد الههة بالطاعة والوفاء 
يأتى النسفى هنا بسيدنا الخضر على أنـه

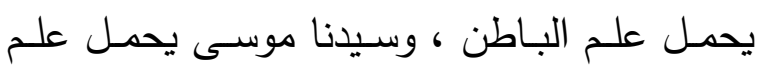
الظاهر ، فأرباب علم الباطن رزقهم جاهز ومعد

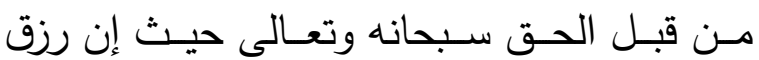
الآخرة مستفرغ من كل نشاط كسبى بل هبة إلهية ـ أما أرباب علم الظاهر فرزقهم مكتسب لأن رزق هن

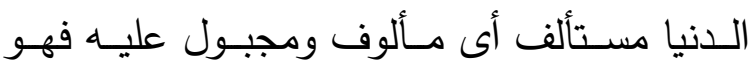

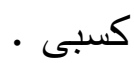

ويستـند فـى الحكايـة السـابقة إلىى الآيـة

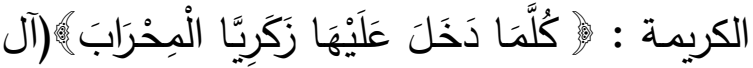

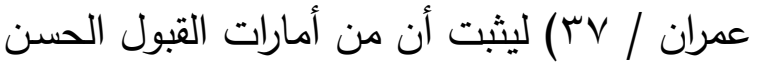

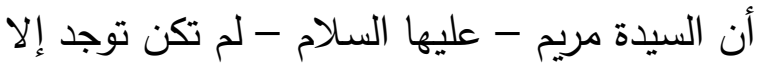

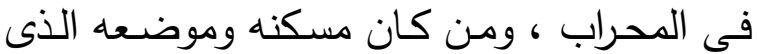
يتعبد فيه هو الدحراب ، فذلك عبد عزيز . ويقـال مـن القبـول الحسـن أنـهـ لــ يطرح

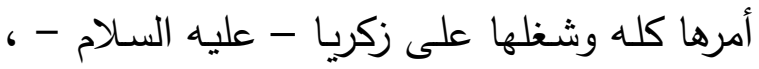
فكان إذا دخل عليها زكريـا ليتعهدها بطعام وجد الـا عندها رزقاً ، ليعلم العـاملون أن الله سـبحانه لا لا لـان يُلقى شغل أوليائه على غير ، ومن خدم ولياً من أوليائه كان هو في رفق الولى لا إنه تكون عليه

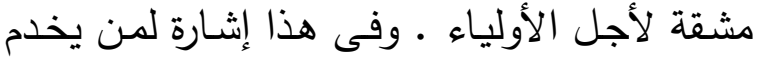
الفقراء أن يعلم أنه فى رفق الفقراء ـ ثم كان زكريا

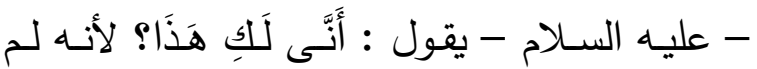
يكن يعتقد فيهـا استـحقاق تلـك المنزلــة ، وكـان يخاف أن غيره يغلبه وينتهز فرصة تعهدها ويسبقه

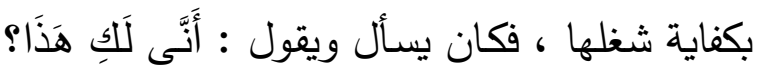
ومن أتاكَ به ؟ وكانت مريم تقول : هُوَ مِنْ عِندِ اللهِ لا من عند مخلوق ، فيكون لزكريا فيه راحتان

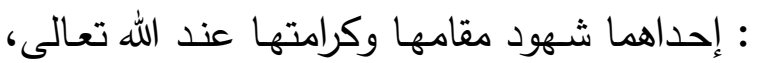

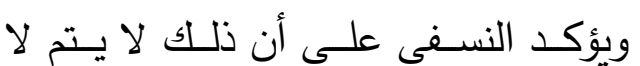

بموت السالك موتاً إرادياً قبل أن يكون موتاً طبيعياً

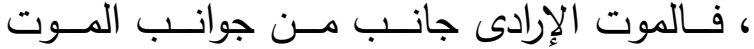
المعنوى ، فيه يصل العبد إلى مقام تنقطع عنهـ أوصافه ، ويقوم الحق مقامه فى جميع الحالات . ويمثل المؤلـــــ بحكايـة لسـيدنا موسـى والخضر - عليهما الصـلاة السـلام - ليبرهن فيها على أصحاب الهمة والقدرة قائلاً :

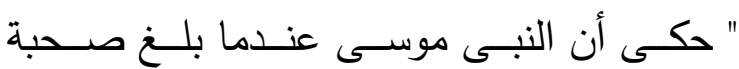

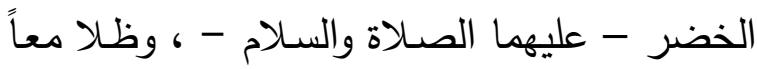
• ذات يوم كانا جائعين فى فلاة ما ، حلَّ غزال وربض بينهمـا ـ كـان ذلك الجانـب الــى أمسام الخضـر مطويـاً، وذاك الجانـب الذنى كـان أمسام

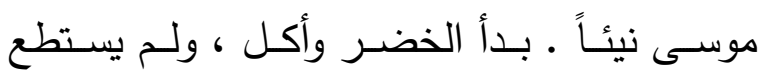

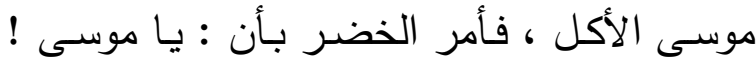

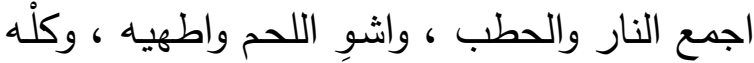
، فسأل موسى الخضر : كيف ناحيتك مطبوخـة وناحيتى نيئة ؟ ! فقال الخضر : يا موسى أنا فى لي

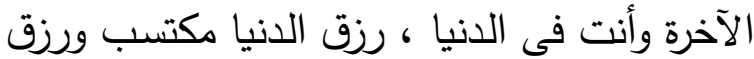
الآخرة جاهز ومُعد ، ورزق الدنيا مستألف ورزق الاحت التان الآخرة مستفرغ ، الدنيا مقر العمل والآخرة مقر

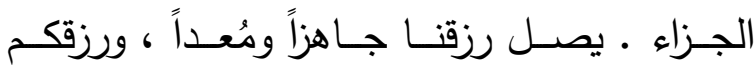

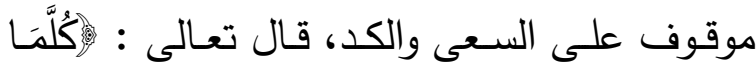

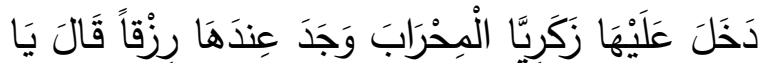

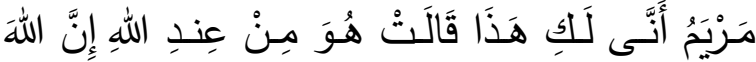

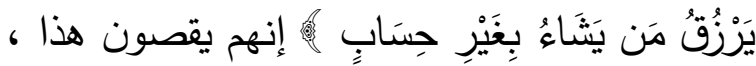

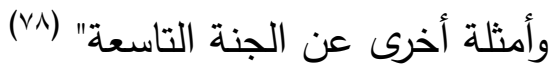


الأنس ، لا يراهم أحد فى الدنيا ولا فى الآخرة (r)

والثانية أنه لم يغلبه أحد على تعهدها، ولم يسبق به

وينهى النسفى رسـالته بأن الله تعالى هو المـانح الواهـب القـادر على الكمـال، ومـا يوهـب لإنسـان مـن قدرة فهى أمـر مـن الله ، والثـريعة

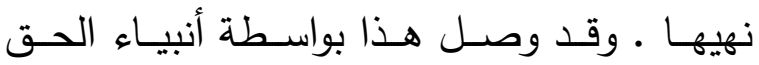

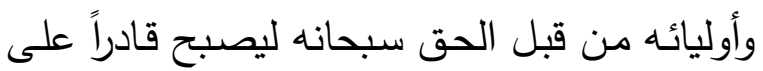
قضاء الأمر والبعد عن النهى .

وأن ما يبلغه الإنسان من علم ومعرفة هو كرامة الإنسـان فى علم الحق والأخلاق الحميدة ، ويؤكد المؤلف على أن مـن يزيــــ علمـه وأخلاقـه تكون كرامته وقربه إلى حضرة الحق أكثر . وعلى العبد أن يكون راضياً قانعاً ، ففى لُ رضـاه يبـــن الكمـال حيـث إن كثيـراً مـن الأنبيـاء والأولياء والملوك والسـلاطين كانوا يريدون أشياء غير موجودة ، ولا يريدون أشياء موجودة ، لكن الله يحكم فى ملكه وملكوته وجبروته بنفسـه مستنداً

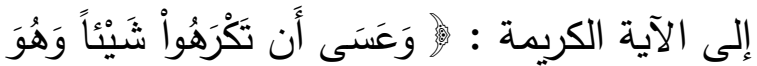

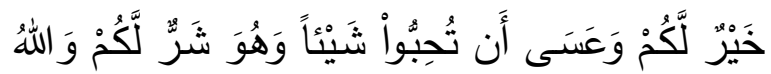

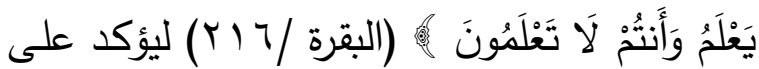

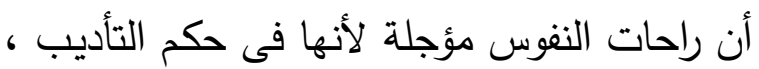
وبالعكس من هذا راحات القلوب فإنها معجلة إذ هـى فى وصـف التقريـب ، فالسـعادة فى مخالفـة

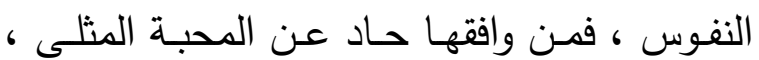
كمـا أن السـعادة في موافقة القلوب ، فمـن خالفها زاغ عن السَّنة العليا (ז^). والحمد لله رب العالمين
إن حكاية الخضر وموسى هنا يتجلى فيها

أن العبــد عنــدما يبـــن مقــام الولايـة، يتــولى الله سـبحانه أمـره ورعايتهـه كمـا ورد فـى الآيـة الكريمـة

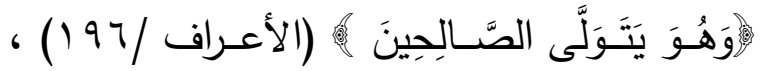
فهو يرى أن مقام التصوف هو حد الولاية ، يقول النسفى : " أيها الفتير ! يجب على السـالك أن يقطع عدة منازل ليبلغ مقام التصوف ويصبح اسمه صوفياً ، ويجب على الصـوفى أن يقطع عدة منـازل حتى يصـل إلى مقـام المعرفـة ويصـبح اسـمه عارفـاً . وعلى العارف أن يقطع عدة منازل حتى يبلِغ مقام الولايــة ، وتصـــبح شـــرته بــالولى • إن مقـــام التصوف مقام عال ، قليل من السالكين من يصل إليه ، فمقام التصوف هو حد الولاية " (•^). وتفصـيل ذلــك أن الولايـة هـى الإطـلاع ع على الحقائق الإلهية ومعرفة ذاته وصفاته وأفعاله كشفاً وشهوداً من الله خاصة من غير واسطة ملك الك

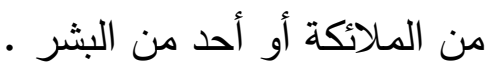
ومقام التصوف هو حد الولاية حيث ينال كل ولـيّ من الأولياء مـا ينـال من الكرامـة بحسن

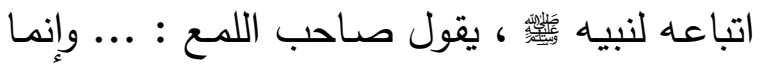
يعطى الأولياء رشاشـة مما يعطى الأنبياء عليهم

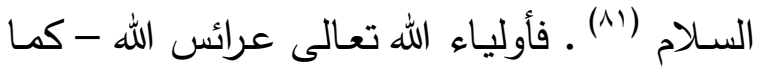

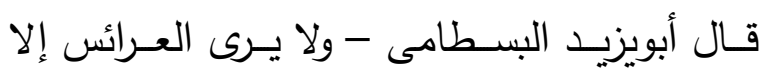
المحرومون ... وهم محجوبون عنده فى جحاف

\section{الخاتمـــة :}


- V - V

توصلت الدراسة إلى مجموعة من النتائج

فى العرفان - بين آدم والروح ، وحواء والجسد

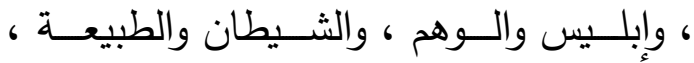

والطاووس والثهوة ، والثعبان والغضب ليثرح من خلالهم الطريق إلى الله.

1

الثرع ، وحقيقة النار فى المخالفة أى مخالفة · الشرع

^ - - أن السـاللك الصـادق فـى طريقـه إلـى الله

يمنحه نوراً يتجلى من الحق سبحانه عليه ، فيستطيع رؤيسة صـفات الله ويعرفهـا ويعـرف كنهرا حتى يبلغ الواصل منهم مقام الولاية . 9 شـجرة هـى شـجرة الهمــة والقدرة ، فمـن يصـل إليها يتولى الله أموره وأفعاله . • - أن ما يبلغه الإنسان من علم ومعرفة هو كرامــة الإنسـان فـى علـم الحـق والأخـاقل

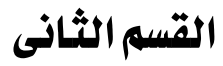

\section{تربمة " رسالة فى شرح الجنة والنار"}

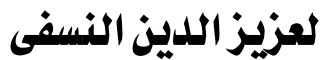

الحمد لله رب العالمين والعافية للمتقين ، والصـلاة

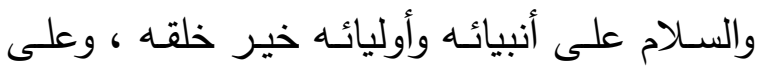
آلهم وصبحهم الطيبين الطاهرين • 1 - أمـا بعـد ، هكذا يقـول أضـعف الضـعفاء وخـادم الفقـراء عزيـز بـن ححمد النسـفى أن جماعـة الفقـراء - زادهـم الله - طلبــوا مـن هـذا الفقيـر أن أجمع رسـالة فى الجنـة والنـار • تفسر فيها ماهيـة حقيقة الجنة والنار ، وما هى حقيقة الجمال والقبح ، وأن أفسر فيها كم جنـة وكم نـار موجودة، وأى

r - أن أبواب الجنـة تتجلى للسـالك من خـلال

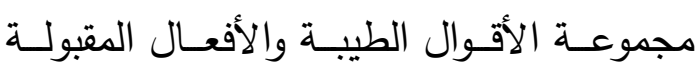

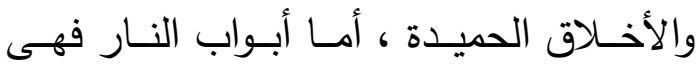
مفتوحـة ومعـدة لأصــاب الأقوال والأفعـال

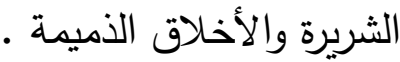
r - - أن أبواب الجنة الثمانية تعمل بأمر العقل ، بينما أبواب النار تعمل بأمر الطبيعة . ع - - أن لكل جنــة مـن الجنـان الثمانيـة شـجرة

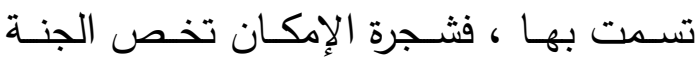

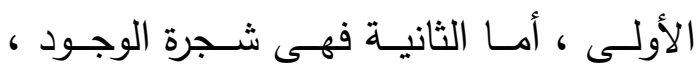

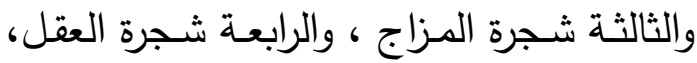
والخامسة شجرة الخلق ، والسادسة شجرة العلم ، واسم الثـجرة السـابعة شجرة نـور الله ، أمـا الثجرة الثامنة فهى شجرة المشاهدة .

0 - أن أغفل المؤلف مضمون الجنة الخامسة

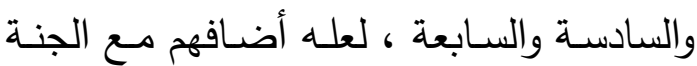
الرابعة حيث انتقل فجأة إلى الجنة الثامنة . 1 إليها من خلال المجاهدات والرياضـات والتى التى التى ينبثق منها أحوال ومقامات يتدرج السالك فيها 
الفصـل الثـانى : فـى ثــــح أبـواب النـاروأبـواب

الجنة

ع - - اعلم أن البعض يقول إن أبواب النار سبعة

، وأبواب الجنة ثمانية ـ وهذا كلام صحيح أيضاً ،

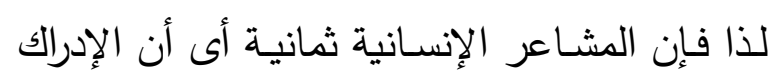

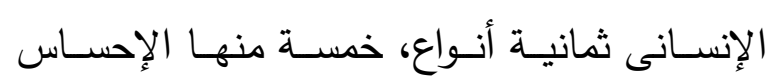
الظاهر والخيال والوهم والعقل ، وكل شىء يدركه الإنه

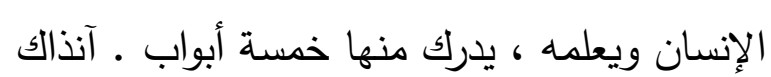

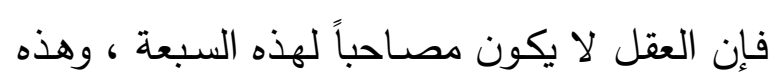

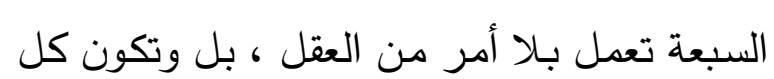

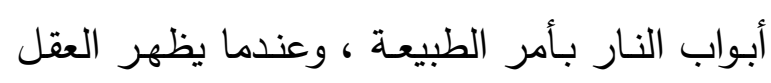

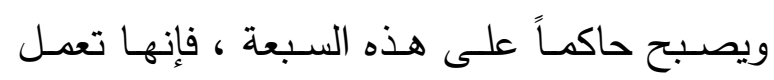
بأمر العقل ، وتصبح كل أبواب الجنـة ثمانيـة .

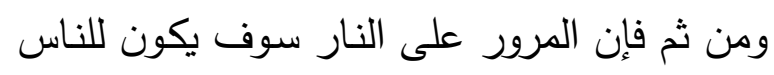
جميعاً فى البداية ، ثم يصلون بعد ذلك إلى الجنة

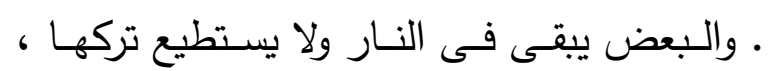
والبعض الآخر يعبر منها ويصل إلى الجنة :

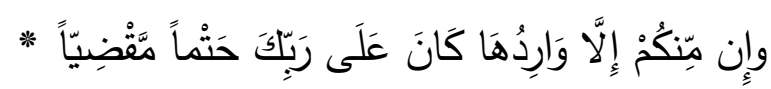

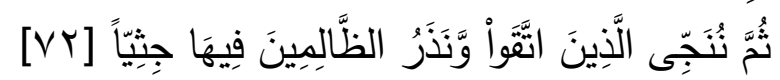

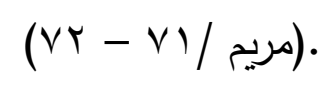

0 - أيها الفقير ! يظل أغلب الناس فى النار ،

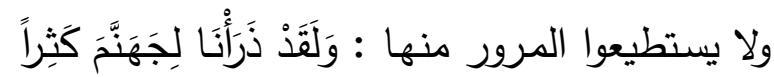

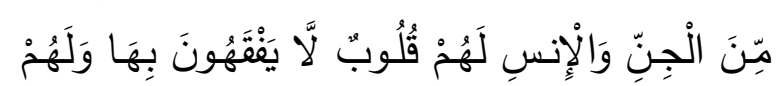

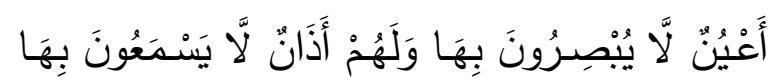

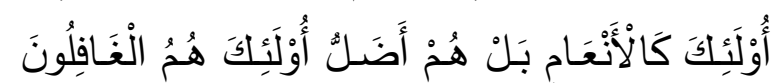

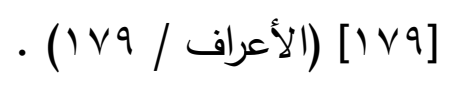

7

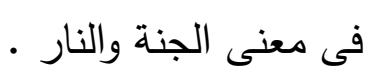

جنة يكون فيها آدم وحواء ، وما هـى الثجرة التى

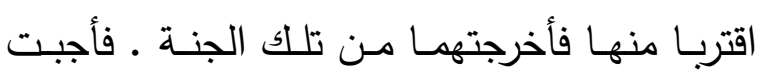

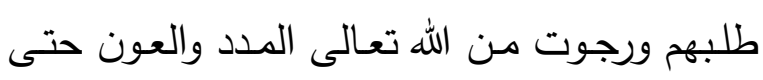

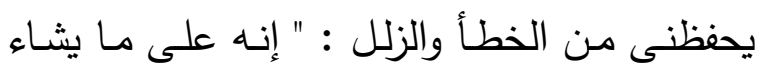
قدير وبالإجابة جدير" . r - أيهـا الفقيـر ! قبـل أن كـــان آدم وحــواء وقصتهما المعروفـة ننقد الآن بشريتهما ، وبعدها

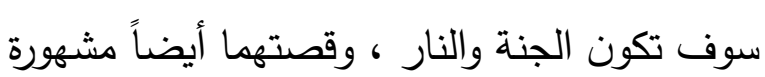

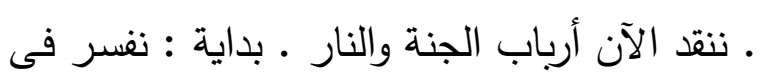

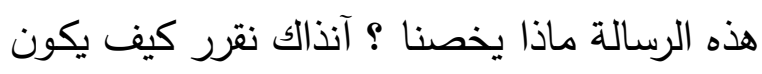

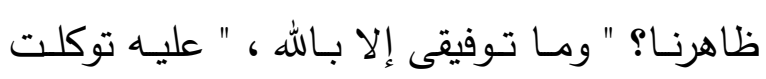

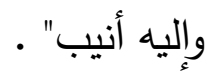

\section{الفصل الأول : فى شرح الجنة والنار الآنية وفى}

\section{شرح آدم وحواء الآن}

ب- اعلم - أعزلك الله فـى الـارين - أن حقيقـة

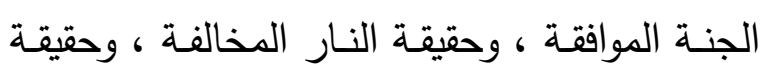
الخير إدراك المراد ، وحقيقة الشر عدم إدراكه .

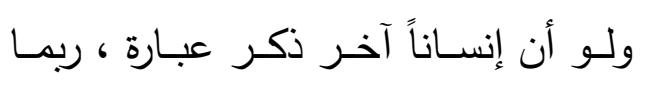

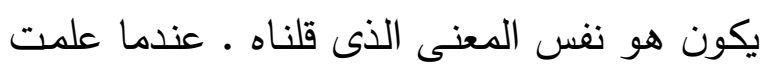

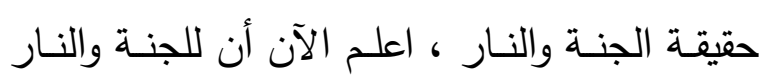

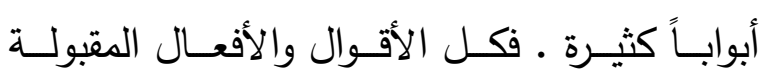
والأخـلاق الحميــة أبــواب للجنــة ، وكـل الأقـوال

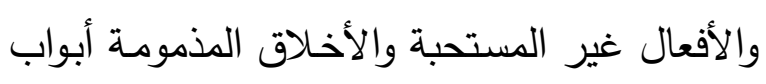

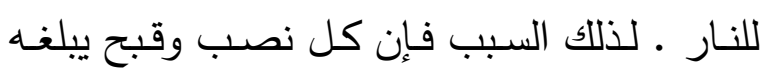

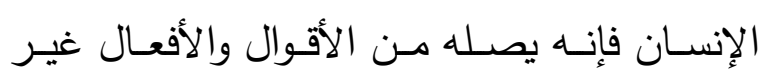

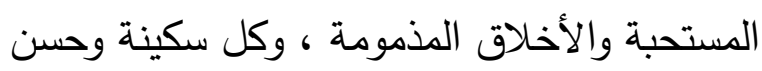
ييلغـه الإنسـان فإنـهـ حصـل مـن الأقوال والأفعـال المحمودة والأخلاق الحميدة . 


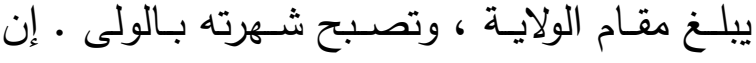
مقام التصوف مقام عال ، من يصل إليه قليل من السالكين ـ فمقام التصوف هو حد الولاية ـ

11 - أيها الفقير ! مـادام العقل لم يبلـغ مرتبـة العشق ، فعصا السالك إما أن تعمر عالمه ، وإما

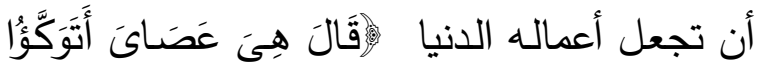

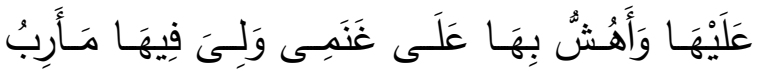

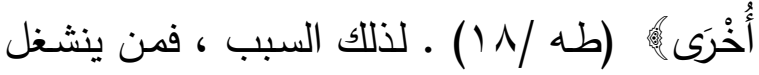

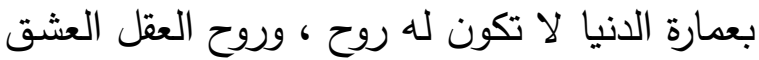

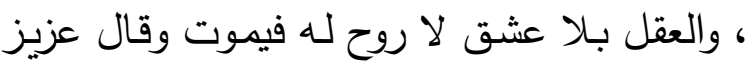
بسر هذا:

لو لم يوجد القلب فكيف يبنى العشق وطنا ولو لم يوجد العشق فأى عمل يكون للقلب r I - أيها الفقير ! يرد السالك خطاب بان انبذ

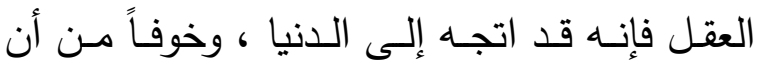

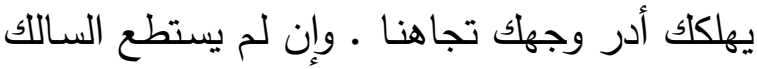
أن ينبذ العقل فإن العشق ينبذ العقل دوماً ويدير

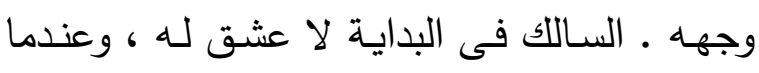
يبلغ مرتبة العشق فإنه يلقى العقل ، وعندما يلقيه يراه الثعبان فيخاف ، ويكون خوفه هلاكاً للسالك. سا - أيها الفقير ! " بضدها تتبين الأشياء " .

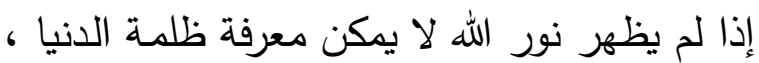
وكل من يبكى عليها ويتوقف على لذاتها وشهواتها

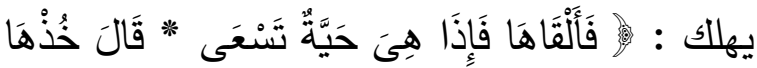

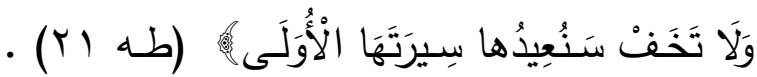

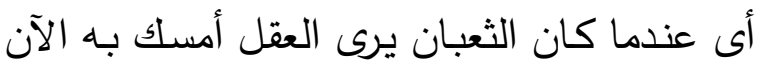

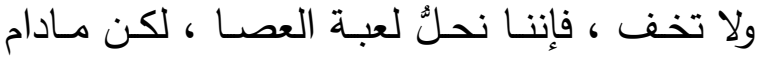
للدنيا شـأن ، فإنها يتعثر إلى الآن ، لكن طالهـا

\section{الفصل الثالث : في شرح منازل الناروالجنة}

V - V اعلـم أن للنـار والجنــة منــازلا ، وطريـقق السـالكين جميعاً على هذه الجنان والنيران ، وأن

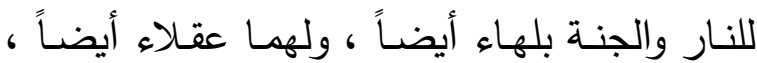
ولهما كذلك عشاق • وللنار والجنة بلهاء مخالفون ومناسبون ، ولابـــ أن يكسون للنسار والجنـة عقـلاء مناسـبون ومهـاجرون ، وأن للنـار والجنـة عشـاق للحجاب والكثف .

1 - أيها الفقير ! إن العشق نار تتطفى فى

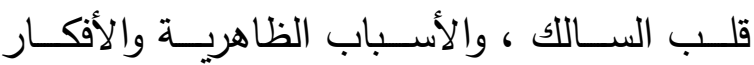

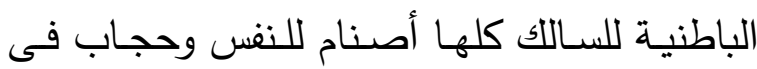
طريق السـاللك لا يحيد عنهـا مـرة واحدة ـ مـادام السالك بلا قبلة ولا صنم (^) ، فإنه يصبح ظاهراً وصافياً ومجرداً ـ " الله فرد ويحب الفرد " . 9 - أيها الفقير ! العشق عصا موسى ، وعالم

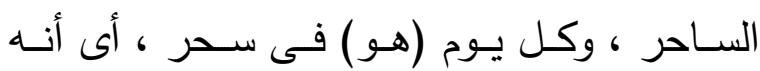
يمارس الخيال كل يوم فينخدع الناس فى الدنيا بممارسـة الخيال . ويفتح العشق فيـه على الدنيا

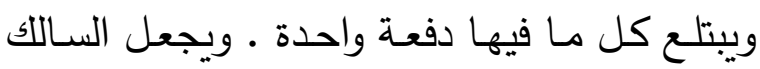

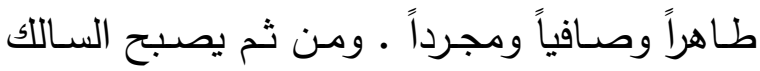

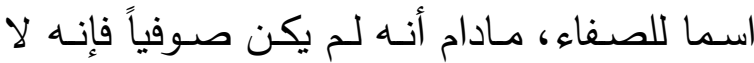
يكون صافياً ، وعندما يصبح صافياً يصير صوفياً • 1 - أيها الفقير ! يجب على السـالك أن يقطع عدة منـازل ليبلـ مقام التصـوف ويصبح اسـمه صـوفياً ، ويجب علـى الصـوفى أن يقطـع عـدة منازل حتى يصل إلى مقام المعرفة ويصبح اسمه عارفاً . وعلى العارف أن يقطع عدة منازل حتى لعى إعلى 
فجاء الخطاب بأن : يا آدم اسكن فى هذه الجنة

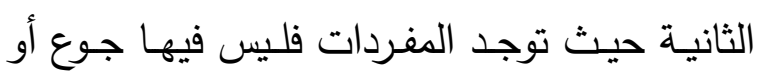
عطش أو عراء ، وليس فيها عناء القيظ والبرد .

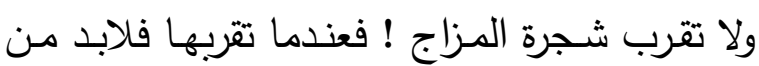
الخروج من هذه الجنة الثانية ، وعندما تخرج من

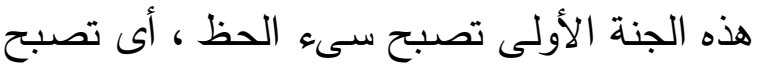
محتاجـاً ، حينئذ يظهر الجوع والعطش والعرى

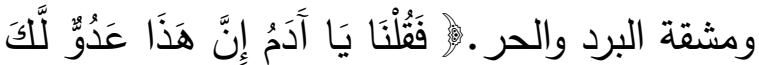

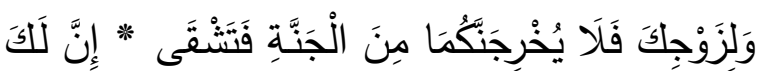

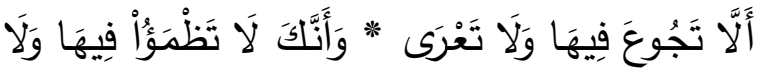

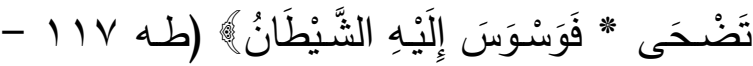
9 (1) ـ ـ (قتربا من شجرة المزاج فجاء الخطاب أن : :

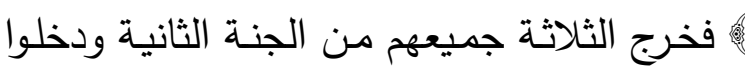

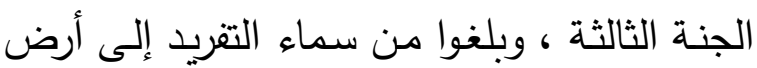

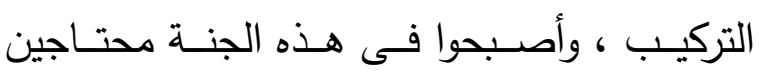

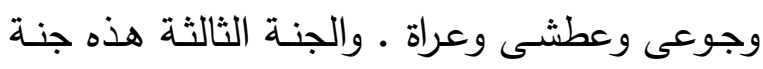

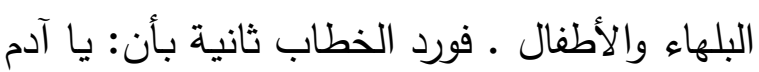
! اسكن فى هذه الجنة الثالثة حيث فيها نعم كثيرة

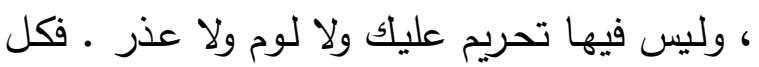

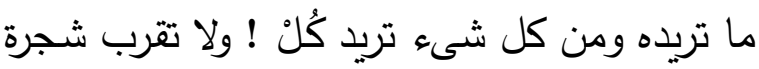

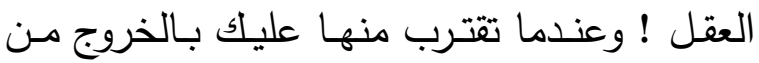
هذه الجنة الثالثة ، وعندما تخرج منها تكون ظالماً

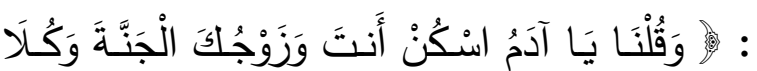

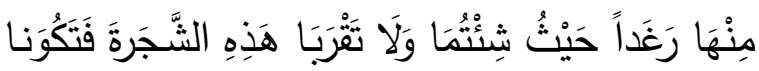

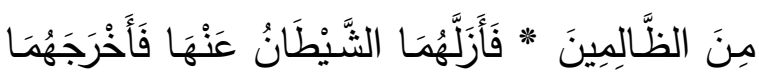

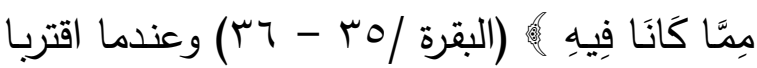
من شجرة العقل جـاء الخطاب ثانيـة بأن :

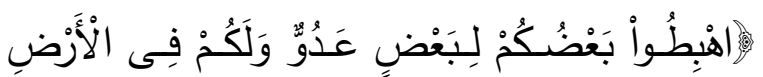

كان السحر يمارس فى الدنيا إلى الآن يمنعك عن

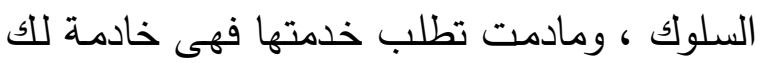
، وتصبح مدداً ومعيناً للك فى طريق الله، لوََالُواً

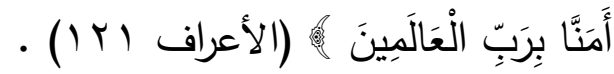
ع ا - أيها الفقير ! تللك الأمانـة التى عرضت

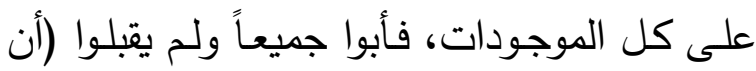

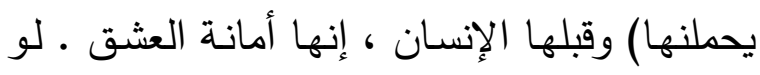

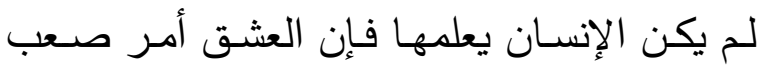

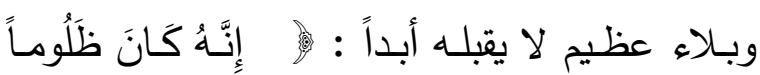

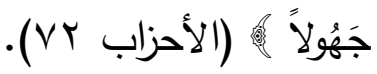
لقد طال الحديث وابتعدنا عن المقصود ،

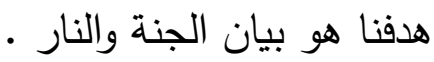

\section{الفصل الرابع : فى شرح آدم وحواء}

10 - اعلم أن النيـران سـبعة والجنـان ثمانيـة ، لكل جنة نـار مقابلة لها إلا الجنة الأولى لا نـار

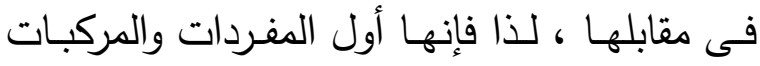

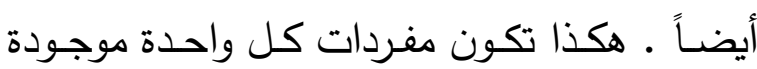

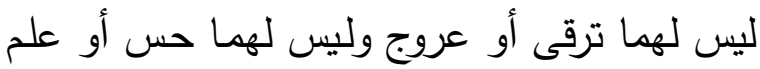
، ولا ألـ لهمـا ولا لـذة ـ مـن قبيـل أنهم جميعـاً يتبعون المزاج ، لا مزاج فى المفردات وهو موجود

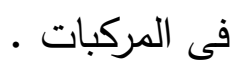

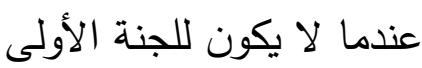
نار فى مقابلها ، يكون آدم وحواء فى هذه

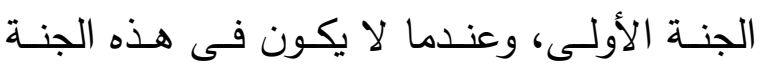
وجـود ولا أضـداد لا يكـون الثـيطان فـى مقابلهـا

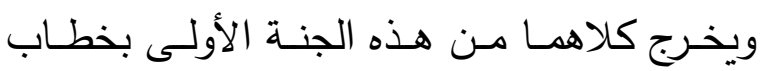
(كن) ، ويبلغا من سماء العدم إلى عالم الوجود لهاب 
اسـم يـرتبط اسـم تلك الجنـة بتلك الثـجرة ، فاسـم الشــرة الأولـى شـجرة الإمكـان ، واسـم الثـجرة الثانية شـرة الوجود ، واسـ الثجرة الثالثة شجرة المـزاج، واســم الثـجرة الرابعـة شـجرة العقل، واسـم الثــرة الخامســة شـجرة الخــق ، واســم الثــرة السادسة شجرة العلم ، واسم الشجرة السابعة شجرة نور الله ، واسـم الثـجرة الثامنـة شـجرة المشـاهدة . مادام الساللك لا يصل إلى نور الله، فإنه لا يصل

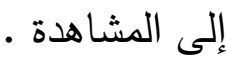
رفيق نورك من يعرف أنه يراك إذ لا يمكن أن يراك نور البصر هذا

19 - أيها الفقير ! إن الأخـلاق المحمودة جنـة

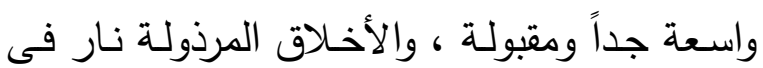
غاية الضيق والقبح ، ولذة الأخلاق المحمودة فى ولى ولى مقابلة لذة العلم والمعرفة مثل القطرة والبحر •

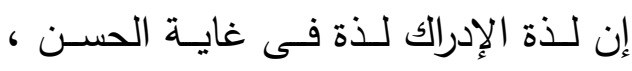

كذلك فإن الشهوات الجسدية واللذات الجسمانية لا تصل إلى لذة الإدراك ـ بالنسبة لجواهر الأشياء

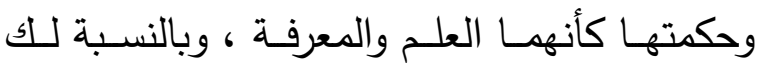
ولخالقلك فالمعرفة لذة عظيمـة ـ كذلك أيضـاً فإن كل جنة نهايتها أفضل ، وكل نار نهايتها أسوأ ، والمعرفة فى تلك الجنة تكون أكثر ، وعندما تكون المعرفة أكثر ، تكون تلك الجنة لهذا السبب أفضل • وكلمـا صـعد الإنسـان إلـى منـازل يكـون أعلـم ويزداد تحقيقه وطلبه ، ويصسب عليه أكثر • من لن هنـا يكون أكثر خوفـاً مـن (الله) مـن يكون أكثر علماً : " أنا أعلمكم بالله وأخوفكم من الله " . مهـا

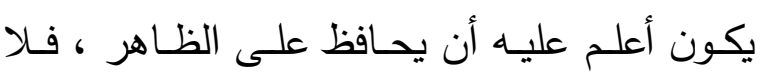

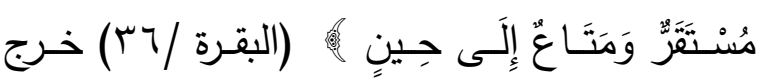

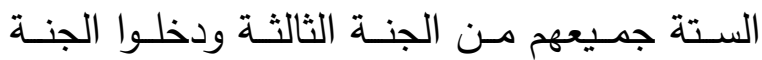
الرابعة .

1 ا 1 - أيها الفتير ! بسبب ذلك أصبحوا ظالمين، وما داموا لم يقربوا شجرة العقل لا يكونوا مكلفين ، ولـم يبـد علـيهم الحـلال والحـرام ، ولـم يصـبحوا

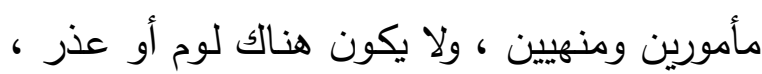
فكل ما كانوا يقولونه ومع كل من كانوا يتحدثون ، وكل ما كانوا يأكلونه ومن كل مكان كانوا يأكلون (فيـه) ليسـوا بظـالمين • عنـدما اقتربـوا مـن شـجرة العقل ، أصبحوا مكلفين ، وبدا الأمر والنهى (لهم) • لو لم يمثلوا للأوامر ويتجنبوا النواهى لأصبحوا ظالمين . IV ، آدم وحواء والثـيطان ، وخرج مـن الجنـة الثالثة ستة هم آدم وحواء والثـيطان وإبليس والطـاووس والثعبـان فـآدم روح ، وحـواء جســ ، والثـيطان طبيعة ، وإبليس وهم ، والطاووس شهوة ، والثعبان غضب . وعندما اقترب آدم من شجرة العقل خرج من الجنة الثالثة ، ودخل الجنة الرابعة ، فسجدت الملائكة جميعا لآدم إلا إبليس لم يسجد وأبى. أى ولى أن كل القوى الروحانية والجسمانية كانت مطيعـة وممتثلـة لأمـر الـروح إلا الـوهم لـم يـــن مطيعـاً

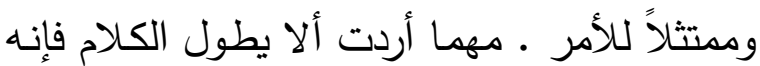
يطول جبرا

\section{الفصل الخامس : فى شرح الشجرة}

11 - اعلم أنه قيل إن هناك ثمان جنان ، واعلم أن فى بداية كل جنة (توجد) شجرة ، ولكل شجرة 
كالرجال ، وضـع قدماً فى الطريق ، فالبقاء فى الطريق ليس من عمل الرجال !ومر على هذه

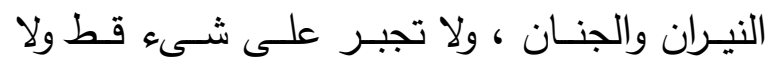

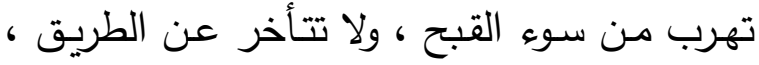

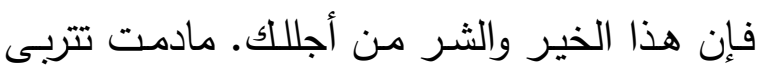
فى الثمس وظلها وتظهر نفسك للملائكة حيث أجبت عليهم بأنك لا تعرف شيئاً هم لا يعرفونه ، فكن فى سعى وكد ، ولا تقض وقتاً فى طريق ، حينئذ تصل إلى نور الله .

وعندما وصلت عرفت نفسـك وعرفتتى وتشرفت بلقائى ، وعندما تشرفت بلقائى ووصلت

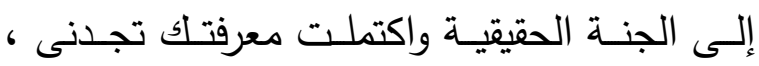

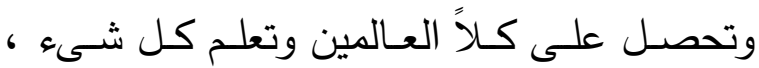
هكذا لا يخفى عليك شىء قط فى الملك والملكوت والجبروت ـ فالجنة هى الجنة ، واللذة هى اللذة . ا ب - أيها الفتير ! مادام السالك لا يشرف بلقاء الله ، فإنه لا يعلم الشىع كما هو البته ولا يراه . فلا شأن للسالك أكثر من أن يعرف الحق ويراه ، ويعلم صفات الله ويراها ـ كل من لا يرى الله ولا يعرف صفاته ، فقد جاء أعمى ومضى أعمى ، عندما يصل السالك إلى نور الله ويتم الرياضـات والمجاهدات باقتدار ، ويصل إلى ذلك المقام فإن

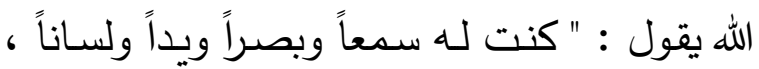
بـه يسمع وبـه يبصر وبـه يبطش وبـه ينطق " ، ويبلغ ذلك المقام بأن قال رسول الله صلى الله عليه وسلم " اتقوا فراسة المؤمن فإنه ينظر بنور الله " . عندما بلغ السالك نور الله ، فهو الآن سالك لنور

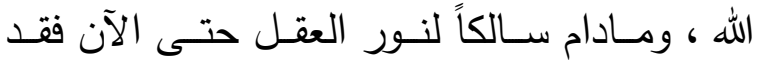
انتهى أمر العقل ، ولا يزال سالكاً لنور الله ـ كلما
يقول شيئاً ولا يفعله إلا بأدب أو حرمة أو عزة ،

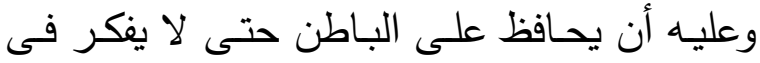
شىء لا بالأدب أو باحرمة أو العزة ـ كلما اقترب لاطي

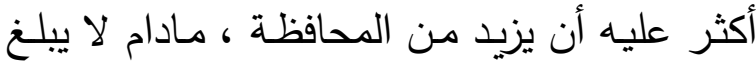

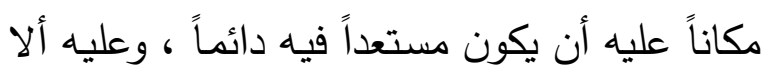
يكون غائباً للحظة ، ولو غاب طرفة عين وقال كلمة ليست من سر الحضور لكان مأخوذاً وفى لعى عتاب " حسنات الأبرار سيئات المقربين " ـ هذا هو حضور أهل التصوف، وهو مقام الخشية، وهو مقام المحبة ، والخشية والدحبة قرينان ، وكلاهما

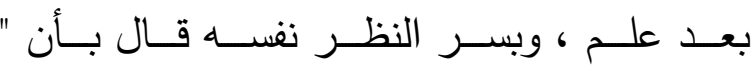
المخلصون على خطر عظيم " . وكل صوفى لم يصل إلى هذا المقام لم

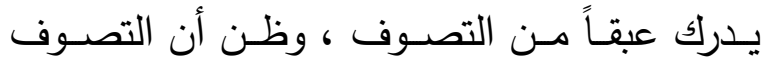
سجادة ومسبحة ـ أيها المسكين البعيد عن المقام ! إن مقــام التصــوف مقـام عـالٍ ـ ألـيس للإنســان

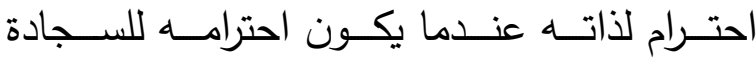
والمسبحة؟! • ب - أيهـا الفقيـر ! كلمـا يصـد الإنسـان إلى

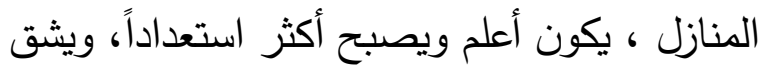

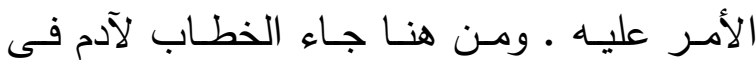

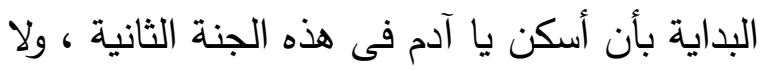

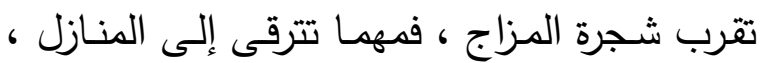

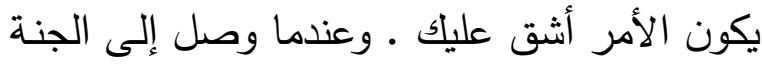

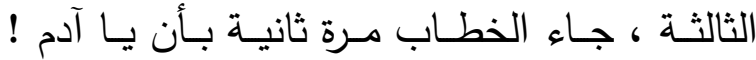

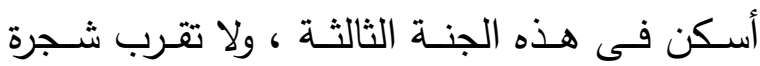

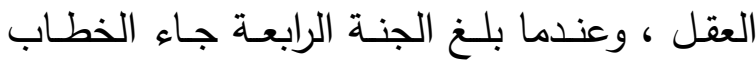
بأن يا آدم عندما بلغت في عروجلك شجرة العقل

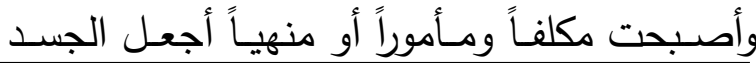


فمن هذه الجنة التاسعة التى تحكى عنها الجماعة

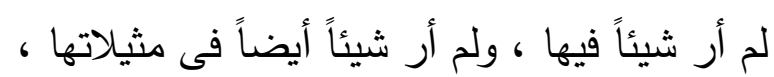

$$
\text { لكنتى قد سمعت الكثير (عنها). }
$$

\section{الفصل السـادس : فى شـرح الجنـة التـاسعة التى \\ أخبر عنها البعض ولا نعلم شيئًا عنها}

گ - T - اعلم أن البعض يقول إن هنالك أناساً كل

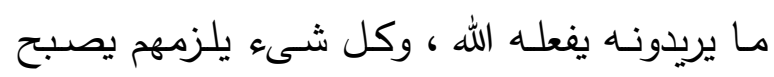
هو ، ويعقدون الهمة فى كل شىء ، ويصبح هكذا يربه

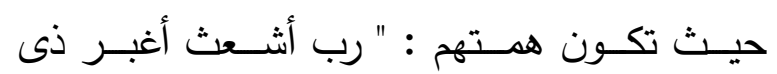

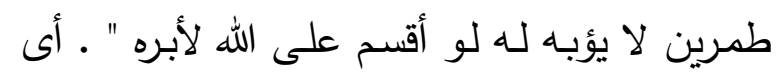

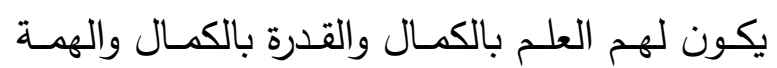
بالكمـال ، وكـل مـراداتهم حاصـلة ، وكـل شـى

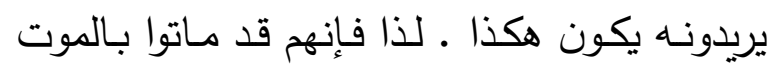
الإرادى قبـل المـوت الطبيعس، وعبـروا مـن الـنيا وهم فى الآخـرة ـ على سبيل المثال ، لـو أرادت هذه الجماعة أن ينزل مطر فى اللحظة التى تمر

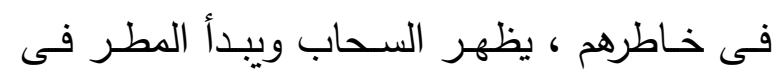

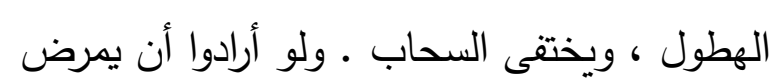

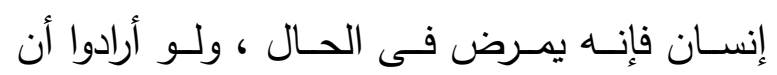

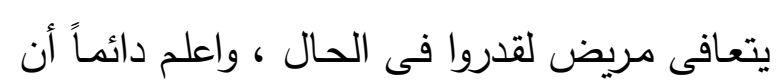

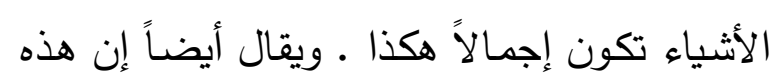

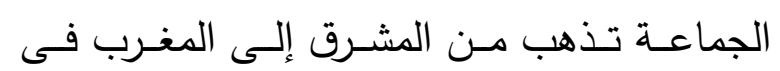
لحظة، وفى لحظة تعود من المغرب إلى المشرق ، ولو أرادوا السير على المساء، ولو أرادوا الطيران فى الهواء ولو أرادوا المشى فى النار (لفعلوا) .

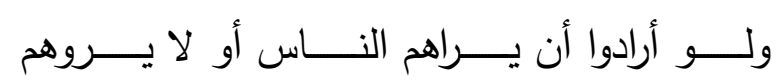
(لاستطاعوا) ، ويصـل رزقهم إليهم جـاهزاً يومياً

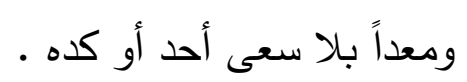

يفيض نور الله فإن كل الحجب النورانية والظلمانية تتكشف أمسام السـالك ، فيرى الله ويعرفهـ ـ أى أن نـور الله يبــن بحر النـور ويـراه ، وبعـدها يكـون مصــاحباً لنـوره فيسـتطيع رؤيـة نـوره ويسـتطيع معرفته - معته

r Y - أيها الفقير ! هذه هى الجنة الثامنة ، وهى عند هذا الضعيف الجنة الأخيرة، وليس هناك جنة

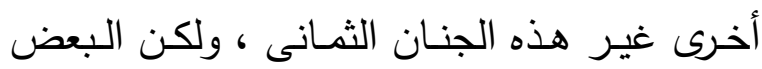
يقول إن هناك جنة أخرى غير هذه الجنان الثمانى ، وفى تلك الجنـة شـجرة ، اســها شـجرة القدرة . عندما يصل السالك إلى نور الله ، ويتشرف بلقائه يصل إلى عين اليقين " أى أنه كان يعلم إلى الآن بعلم اليقين ، والآن يـرى وجـود الله مباشـرة بعـين اليقين ، فليس هنـالك ذرة قط مـن ذرات العـالم لا يكون نور الله عليه بنفسه ، ولا يكون محيطاً بها ، ولا خبيراً بها ، ولا ينهض السالك من وجوده ويؤثر الوجود ويخرج من الغرور والظن • سب - أيهـا الفقير ! مـادام السـاللك لا يعبر مـن

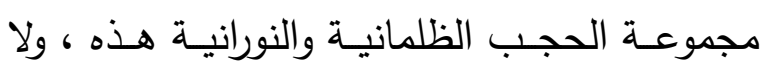
يخرج من الخيال والظن ولا يقدر على المجئ ، فعندما يتجاوز الخيال والظن وعلم باليقين ويراهـا ظاهرة وأنها جميعاً كانت مشكاة ، يصل إلى ذات الله ، وعندما يبلغ ذات الله ، ويؤثر وجوده فإن الله

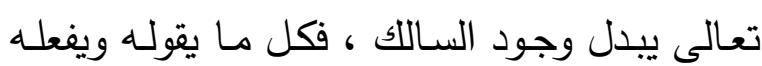
السـاللك فإنـه يقول ويفعله بـالله ، ويصبح السـالك عالماً وقادراً، ويصبح صاحب قدرة وصاحب همة

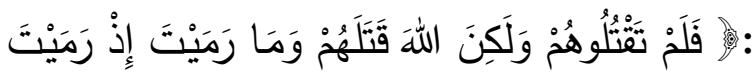

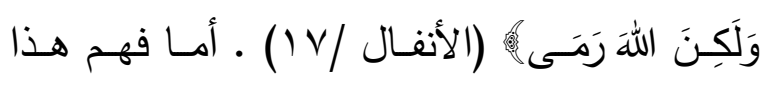
الضعيف لم يبلغ هذه الجنة التاسعة بسبب ذلك ، 
وكـل مـن يـزداد علمـهـ وأخلاقـهـ (فضـلاً) تكـون كرامتـه وقربه إلى حضرة الحق أكثر • TV ورعيـة ورسـول وأمـة، مـن عـالم وجاهل عـاجزون ومساكين يعيشون على الحرمان، وإلا فإنهم آنذالك يصلون فـى الرضـا بالقضـاء إلىى غايـة الكمـال .

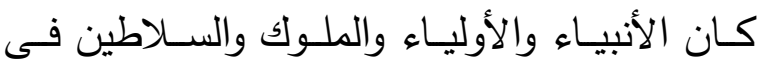
أغلب الأحوال (يريدون) أشياء كثيرة كانت موجودة ، ولا يريـدون أشـياء كثيـرة موجـودة ولا تـزال ـ " وتفرد الحق بـالحكم ": يحكم فـى ملكـه وملكوتهـه وجبروتـه بنفسـه، وهـل أيضـاً يكون مـراد الإنسـان وحرمانه فى ألا يكون محباً لمصلحته وغير محب

" عسى أن تكرهوا شيئًا وهو خير لكم ، وعسى أن تحبوا شيئًا وهو شر لكم" لحرو

(1) عزيزالدين نسفى : مجموعه رسائل مشهور به كتاب الإنسان الكامل ، بإِيش كَتار هانرى

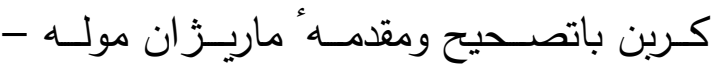

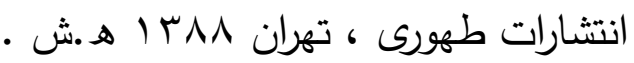
- http://fa.wikipedia.org, p. 1:12. - http://ar, rasekhoon.net.

أحمـد بـن فـارس : معجم مقـاييس اللغـة -

تحقيق عبدالسـلام محمد هارون - الطبعة الثانية

- مطبعـة مصطفى البابى الحلبى - القاهرة ، (9V.

المرجـع السـابق ، معجم مقـاييس اللغــة ،
O - حكى أن النبى موسى عندما بلغ صحبة الخضر - عليهما السلام - وظلا معاً ، ذات يوم كانا جائعين فى فلاة ، فحلَّ غزال وربض بينهما . كـان ذللك الجانـب الــى أمـام الخضـر مطهيـاً ، والجانب الآخر الذى أمسام موسىى كان نيئًاً . بـدأ الخضر وأكل ، ولم يستطع موسى الأكل ، فأمر

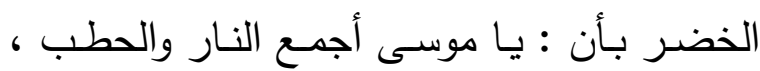
وأشو اللحم واطهيه ، وكُله ـ فسأل موسى الخضر كيف ناحيتلك مطبوخـة ونـاحيتى نيئة ؟! فأجـاب الخضـر : يـا موسـى ! أنـا فى الآخرة وأنـت فى الـدنيا، رزق الـدنيا مكتسـب ورزق الآخـرة جـاهز ومُعد ، ورزق الدنيا مستألف ورزق الآخرة مستقرغ ، الدنيا مقر العمل والآخرة مقر الجزاء ـ يصـل رزقنا جاهزاً ومُعداً ، ورزقكم موقوف على السعى

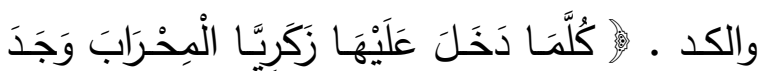

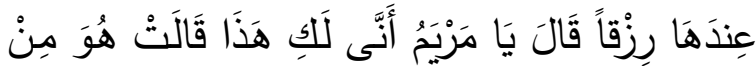

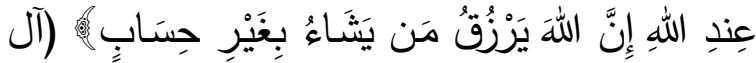

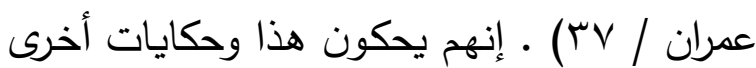
عن الجنة التاسعة . جب - أيها الفقير ! اليوم الذى أكتب فيـه ليس ملكى وليس ملك الرفـاق أيضـاً ، ومـع ذلك : لانك إنكـار فيـهـ ، لعـل الله تعـالى يمنحنـا ويهِنـا فهـو القادر على الكمال • وكل مـا حدث لنا الآن هو أن القدرة لو وهبت لأحد فهى أمر والثريعة نهيها ، فقد وصلت بواسطة أنبياء الحق وأوليائه من قبل الحق، ليصبح قادراً على قضاء الأمر والبعد عن • النهى

كذللك فكل مـا علمنـاه ووصـلنا إليـه هـو كرامة الإنسان (فى) علم الحق والأخلاق الحميدة، 


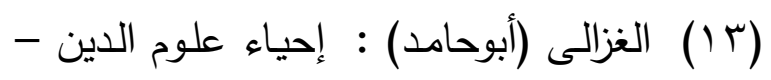

(؟) النسـفى (عزيزالـدين) : رســاله " دربيـان

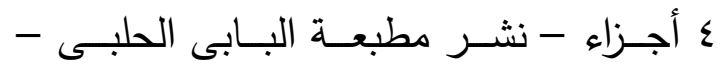

بهشت ودوزخ " ضمن مجموعه رسائل مشهور

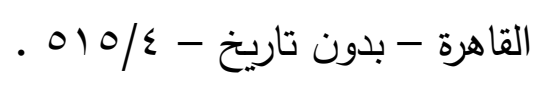

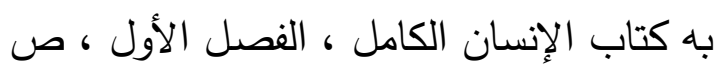

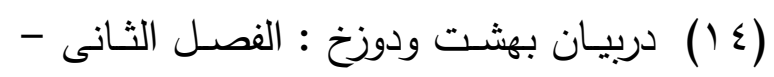
. r.

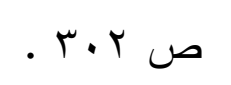

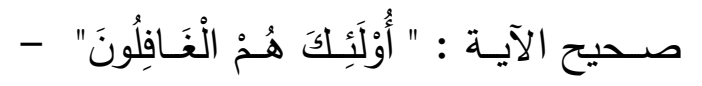

(10) المرجع السـابق ، الفصل الخـامس - ص . (10

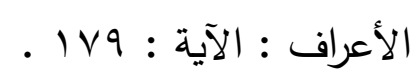

$$
\text { .r. }
$$

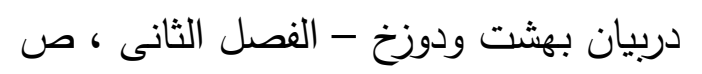

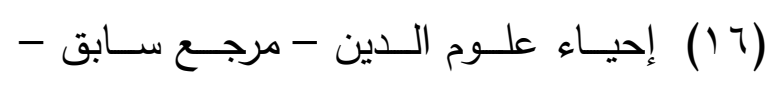
r.r.

$$
\text { .or./s }
$$

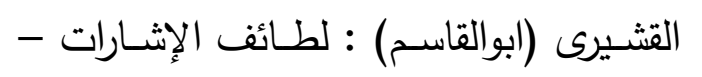

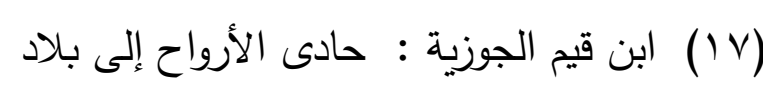

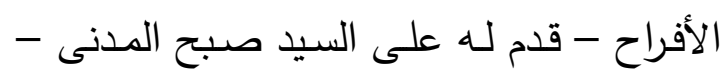

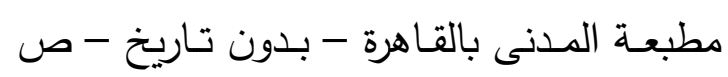

$$
\text { . 1.. - } 97
$$

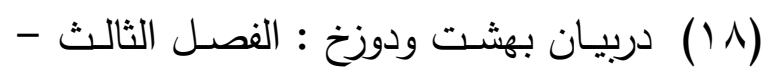

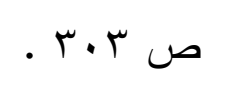

قدمه وحقق له وعلق عليه : د. إبراهيم بسيونى الإنى

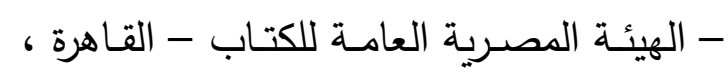

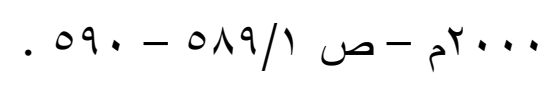

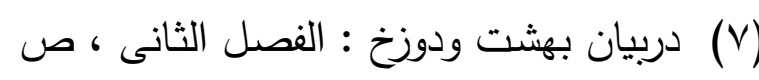

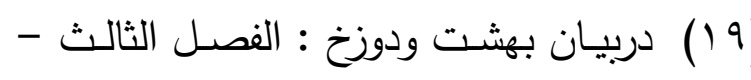

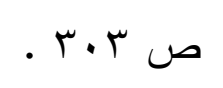

(Y.) السلمى (عبدالرحمن) : طبقات الصسوفية

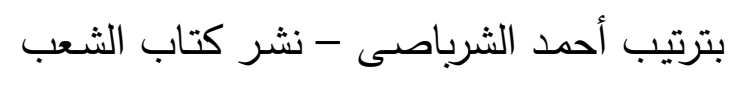

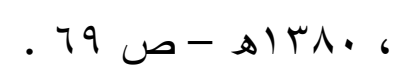

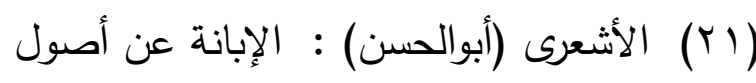

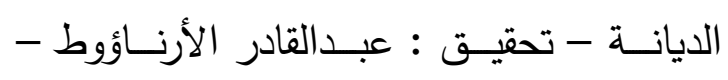

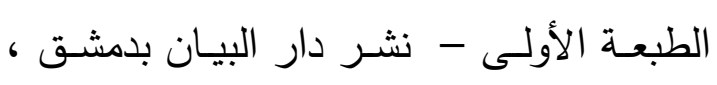

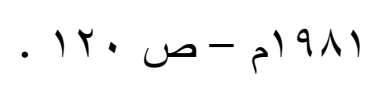

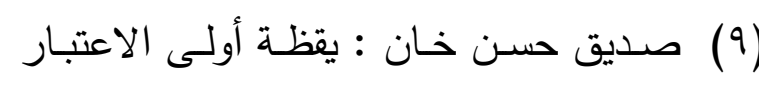
مما ورد فى ذكر النار وأصحاب النار - تقديم وتحقيق د. أحمد حجازى السقا - الناشر مكتبة طلعت بجوار الأزهر - الطبعة الأولى ، القاهرة

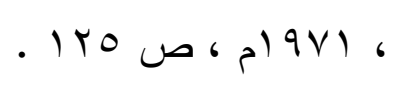

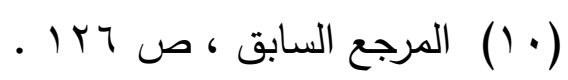

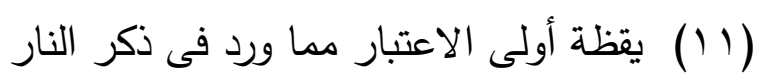

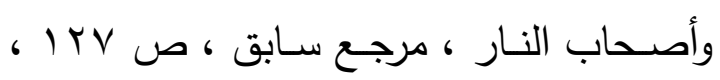

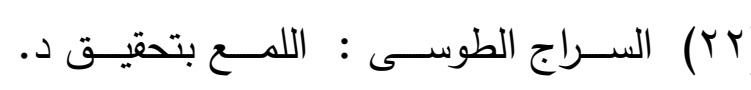

(Y I ) ابـن عربـى (محيـى الدين) : الفتوحسات

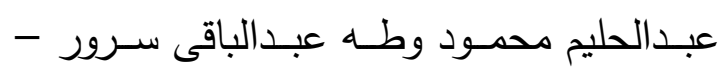

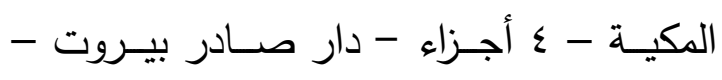

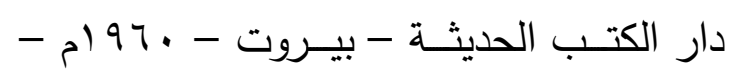

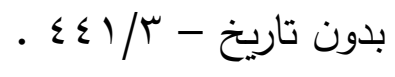


جـاب سـوم - انتشــارات كتابجانـهُ - تهـران

$$
\text { q }
$$

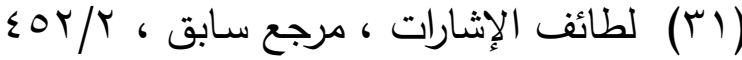

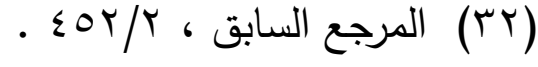

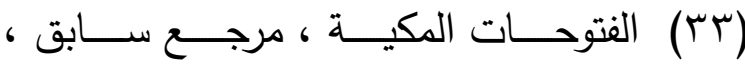

$$
.0 / 4
$$

. rv

(ب) مربيـان بهشت ودوزخ : الفصـل الثالث -

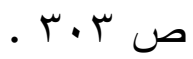

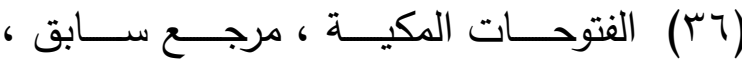
$.7 \leq V / r$

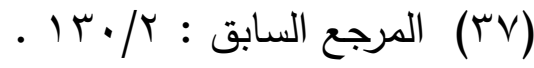

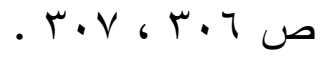

(ب⿳) ابـن قيم الجوزيـة : مـدارج السـالكين بـين

منازل إيالك نعبد وإياك نستعين - r أجزاء -

$$
\text { نشر دار الحديث - بدون تاريخ - } 97 / 1 \text {. }
$$

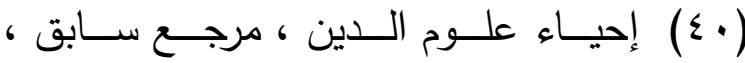

$$
\text { . TV./ }
$$

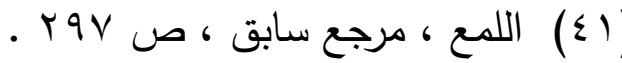

سيد حسين ابراهيميـان : معرفت شناسى در عرفان - جاֶ اول - مركز انتشارات دفتر

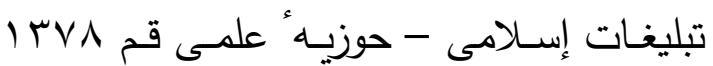
هـ ش - ص ص وب .

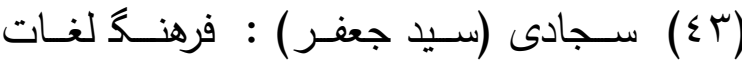
واصطلاحالت وتعبيرات عرفانى - جـاب دوم

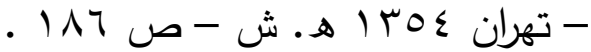

محمد بن المنور : أسرار التوحيد فى مقامات (YT) الثـيخ أبـى ســيد - ترجمــة : د. إســــاد عبدالهادى قنديل - دار الرائد العربى - بدون

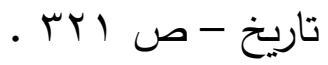

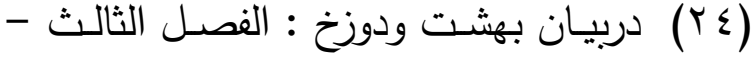

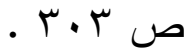
(Yo) نجم الدين دايه : مرصاد العباد من المبدأ إلى المعاد - ترجمـة : على أحمد إسماعيل رسـالة ماجسـتير - جامعـة عـين شـمس . $9 V$ v - p) $9 V V$

- دربيـان بهشت ودوزخ : الفصل الثالث (YT) ص r.

(YV) المعــارف ملحـق بإحيـاء علـوم الـدين - دار الكتب العلميـة - بيروت - بو99 ام - الجزي الخامس - ص سو و وما بعدها .

- دربيان بهشت ودوزخ : الفصـل الثالث (YN)

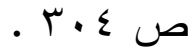

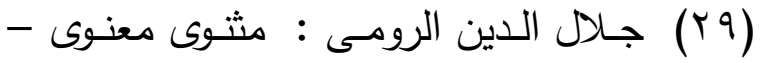
ترجمـه وشرحه : د. إبراهيم الدسوقى شتا - 7 أجزاء - نشر المجلس الأعلى للثقافة - القاهرة $r \cdot 1 / r-\operatorname{b} 1997-$

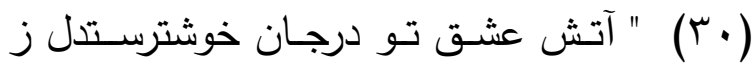
عشقت آتش افثـان خوشترست هركه خورد از جام عشقت قطره اى تاقيامــت مســت وحيـران

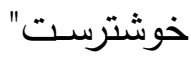
عطار (فريد الدين) : ديوان فريد الدين عطار نيسابورى باتصحيح ومقدمها : سعيد نفيسى - 


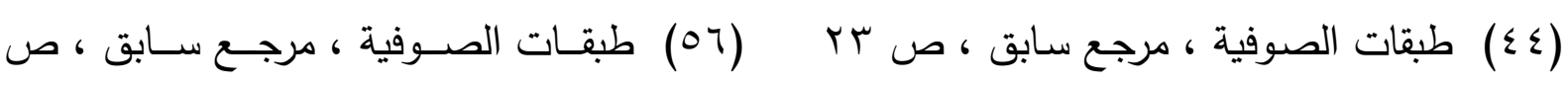
.19

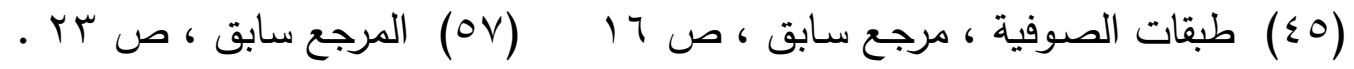

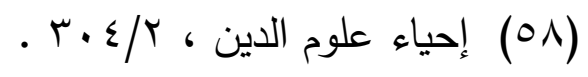

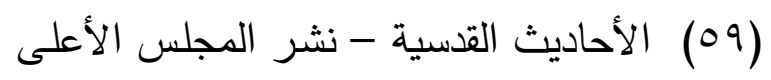

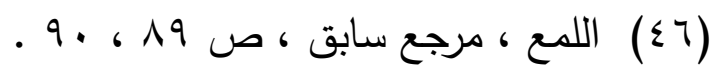

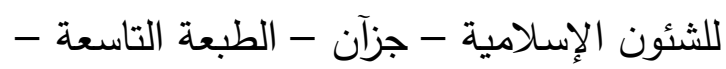

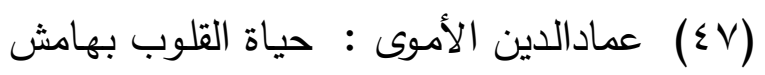

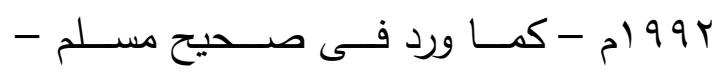

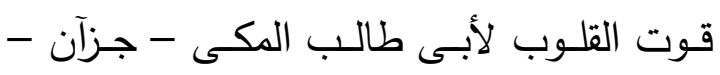

.

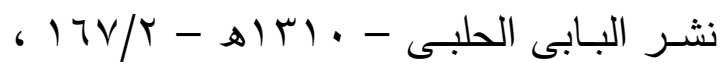

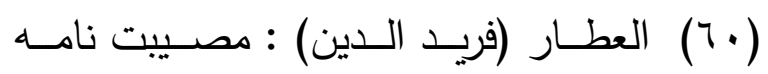

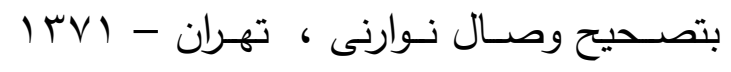

(الحی) الكمشخانوى (أحمد ضياء الدين) : جامع

هـ ش - ص עrr .

الأصول - طبع دار الكتب العربية الكبرى -

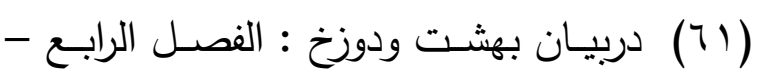

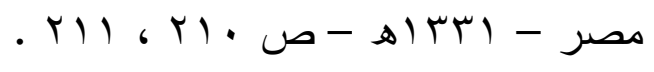

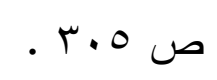

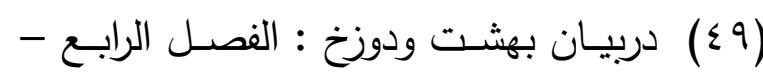

(YT) المرجع السـابق ، الفصل الخـامس - ص

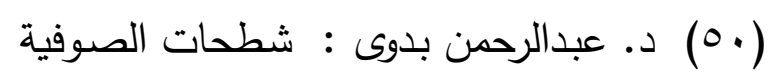

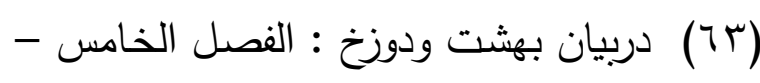

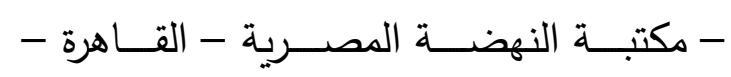

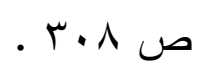$$
\text { - r }
$$

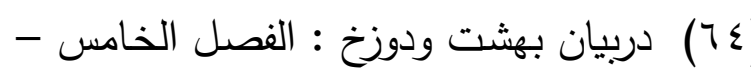

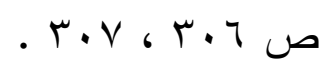

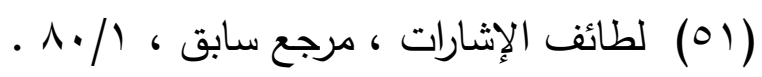

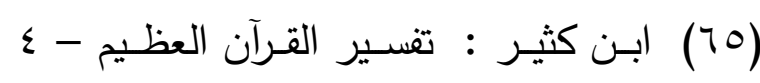

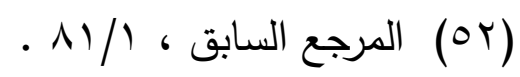

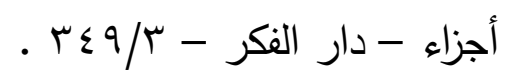

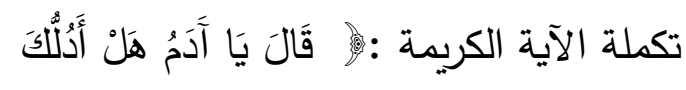

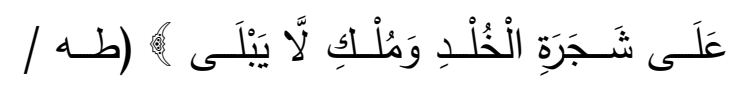

- وقد أخرج هذا الحديث ابن جرير وعبدالرازق . (1)1

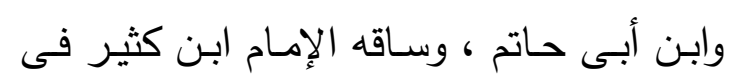

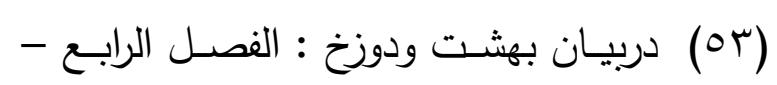

$$
\text { ت تعسيره - أبن }
$$

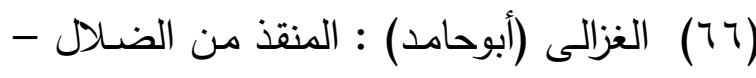

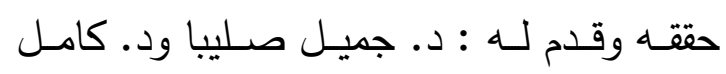

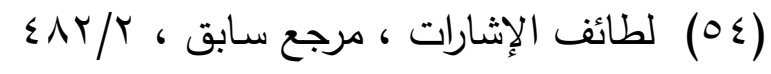

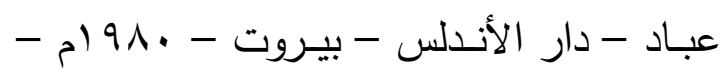

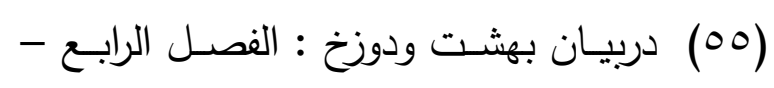




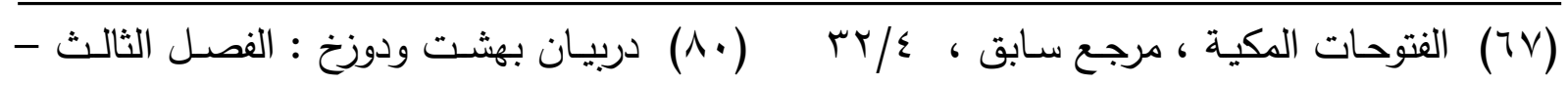
ص r.

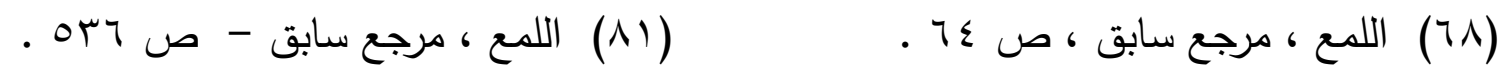

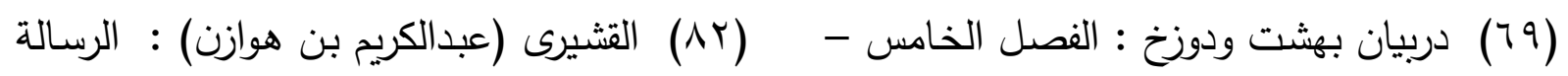

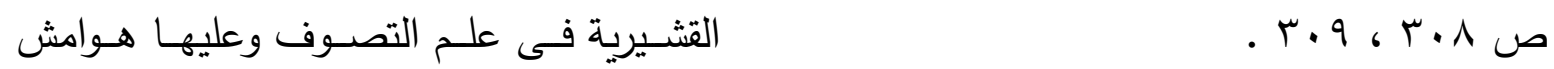

للشيخ زكريـا الأنصـارى - مكتبـة ومطبعـة محمد

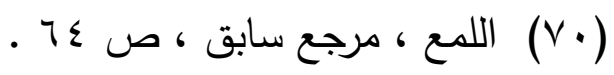

على صبيح - القاهرة - 974

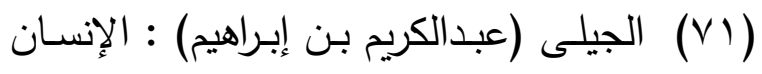

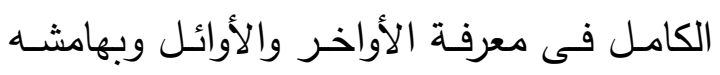

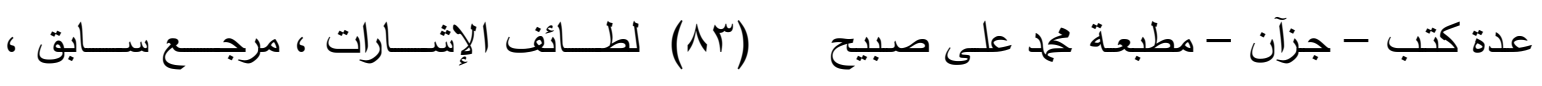

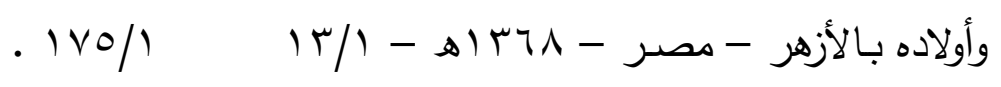

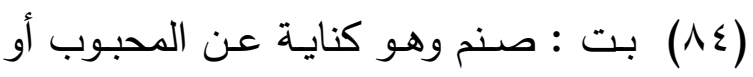

. rT-

المعشـوق - فرهنــ اصــلاحات وتعبيـرات

، مرصـاد العبـاد مـن المبـدأ إلىى المعـاد (VY)

عرفانى

مرجع سابق ، ص •

\section{قائمة بأهم المصادروالمراجع}

أولاً : المصادر العربية والفارسية :

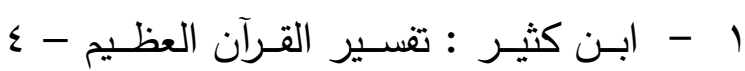

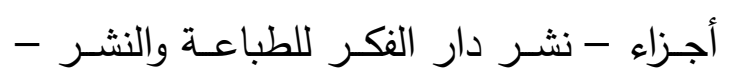

$$
\text { بيروت - بدون تاريخ }
$$

r - الأحاديــث القدســية : جــزآن - نشــر

7 9/1 ، لطائف الإشارات ، مرجع سابق (VT)

- دربيان بهشت ودوزخ : الفصل السادس (V乏)

ص 9.

(V0) جـامع الأصــول - مرجـع سـابق - ص

المجلس الأعلى للشئون الإسـلامية - الطبعـة الطعان

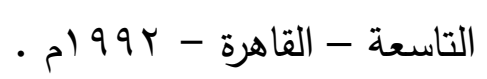

r - عزيـز الـدين نسـفى : مجموعـهُ رسـايل

مشـهور بـه كتـاب الانسـان الكامـل - بـاييش

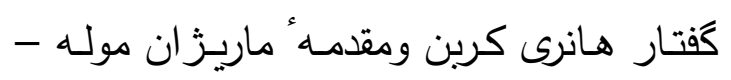

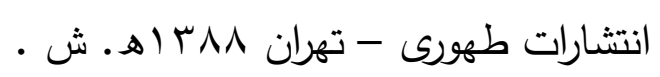

\section{ثانياً : المراجع العربية والفارسية :}

ع - - أحمد بن فارس : معجم مقاييس اللغـة -

السيوطى (جلال الدين) : الجامع الصغير (VT)

- دار الفكـر للطباعـة والنثـر - بيـروت -

$$
. \wedge / r-p \mid 9 \Lambda 1
$$

جـز مسن حـديث قدسى ورد فـى كتـاب (VV)

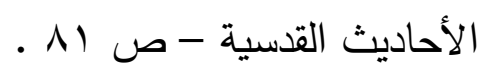

- دربيان بهشت ودوزخ : الفصل السادس (V^)

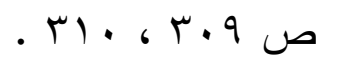

- لطــائف الإشــارات ، مرجــع ســابق (V9)

تحقيـق : عبدالســلام تحمد هـارون - الطبعـة معند 
r - سيد حسين ابراهيميان : معرفت شناسى دهي درعرفان - جاب اول - مركز انتشارات دفتر

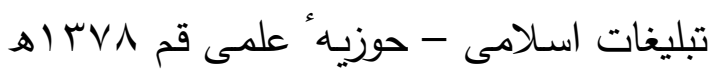

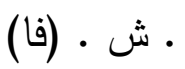

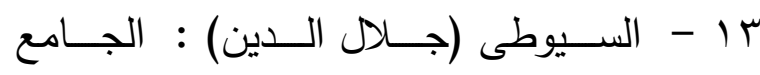
الصغير - جزآن - دار الفكر للطباعة والنشر النر

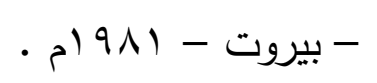

ـ ا - صديق حسن خان : يقظة أولى الاعتبار مما ورد فى ذكر النار وأصحاب النار - تقديم

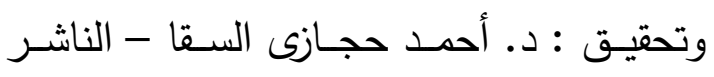

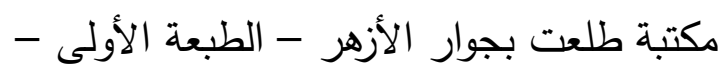
- م) 971

10 - د. عبدالرحمن بدوى : شطحات الصوفية - نشـر مكتبـة النهضــة المصرية - القـاهرة -

$$
\text { - ) } 9 \leq 9
$$

17 - ابـن عربى (محيى الدين) : الفتوحسات

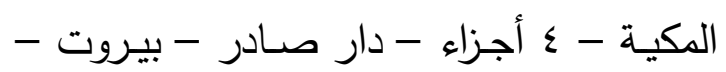

$$
\text { بدون تاريخ }
$$

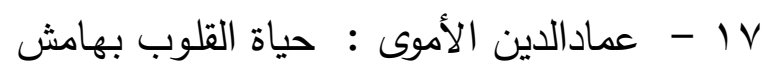

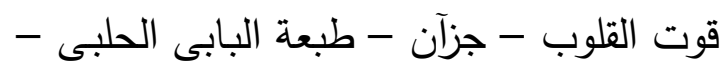

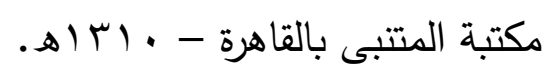

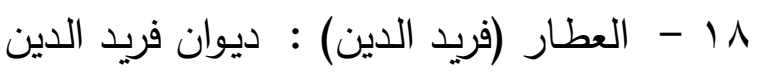

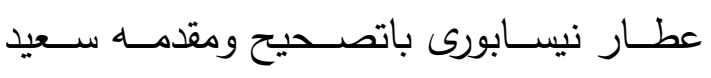

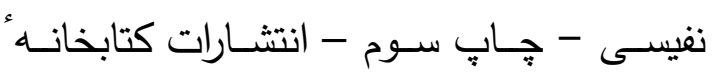

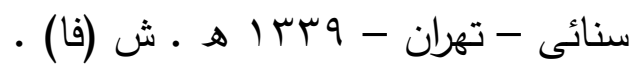
19 ـ 19

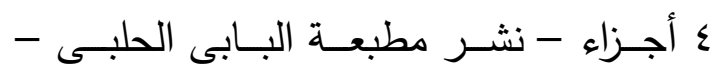

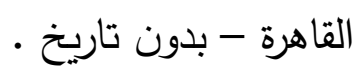

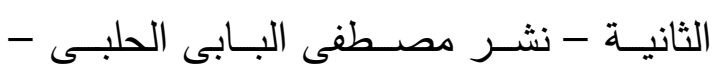

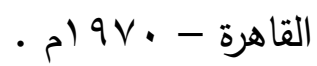
ه - الأشعرى (أبوالحسن) : الإنابة عن أصول الديانة - تحقيق : عبدالقادر الأرناؤوط - نشر الإنة عن النرول

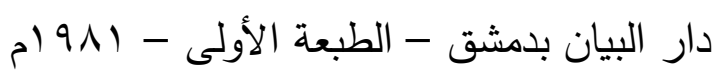
1 - جـال الدين الرومسى : مثنوى معنوى -

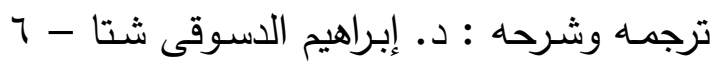
أجزاء - نشر المجلس الأعلى للثقافة - القاهرة - م) 997 V - الجيلى (عبدالكريم بن إبراهيم) : الإنسان

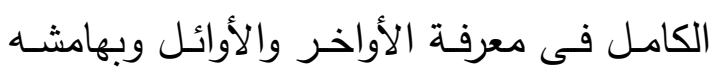
عدة كتب - جزآن - طبعة محمد على صبيح

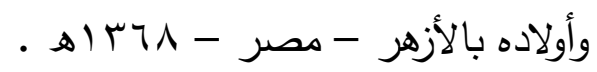
ᄉ - ســادى (سـيد جعفـر) : فرهنـــ لغـات

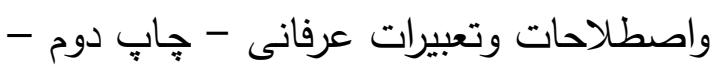

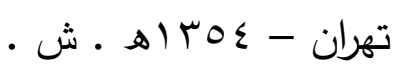
9 بتحقيق : د. عبدالحليم محمود وطه عبدالباقى البح

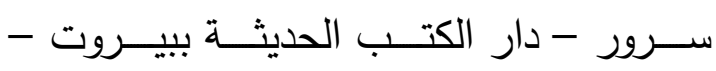
. م) 97. • 1 - السلمى (عبدالرحمن) : طبقات الصـوفية بترتيب أحمد الشرباصى - نشر كتاب الثعب (هب . آمA. 11 - الســــروردى (أبـــوحفص) : عـــــارف

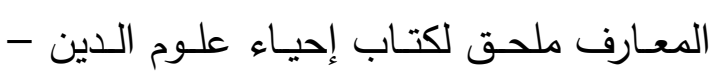
الجزء الخامس - دار الكتب العلمية - بيروت - م) 


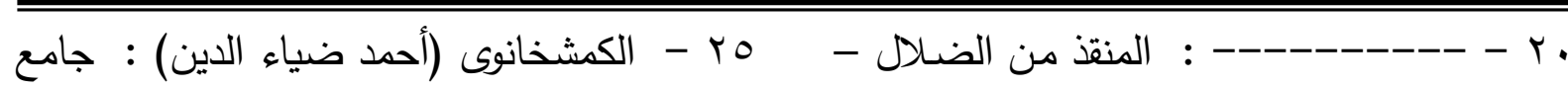
حققهـ وقدم لـه : د. جميـل صـليبا ود. كامـل الأصـول - طبـع دار الكتب العربيـة الكبـرى

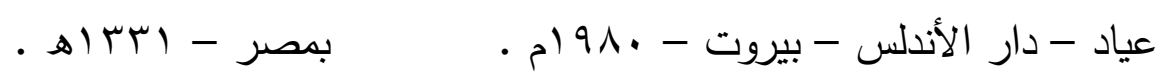

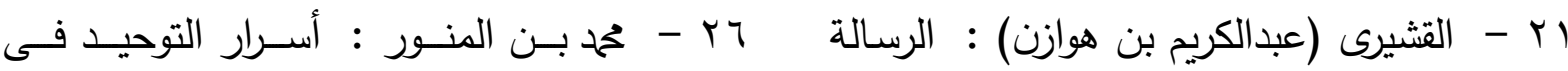
القشيرية فى علم التصـوف وعليهـا هـوامش مقامات الشيخ أبى سعيد - ترجمة : د. إسعاد للشيخ زكريا الأنصارى - نشر مكتبة ومطبعة عبدالهادى قنديل - دار الرائد العربى - القاهرة

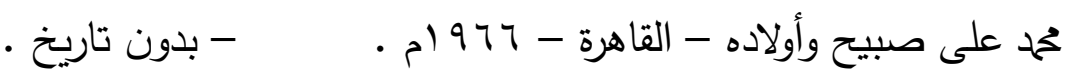

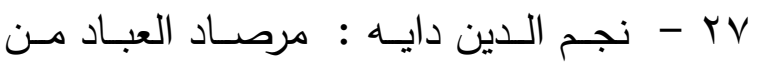
: لطـائف : ل

المبدأ إلى المعاد بسعى واهتمام شمس العرفا -

الإثــارات - قدمـهـ وحققـهـه وعلـق عليـهـ : د. نشر سـازمان انتشارات سـنائى - بدون تاريخ

إبـراهيم بسـيونى - ب أجـزاء - نشـر الهيئة

المصرية العامة للكتاب - القاهرة - . . . بم.

ثالثاً : الرسبائل العلمية :

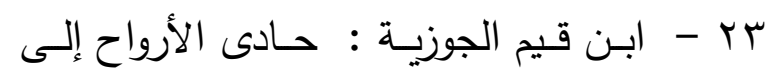

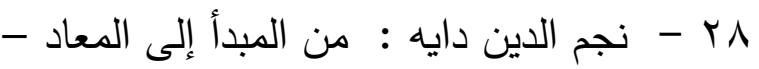
بـلاد الأفـراح - قـدم لـه : على السـيد صـبح ترجمــة : على أحمـد إسـماعيل - رسـالة المدنى - مطبعة المدنى بالقاهرة - بدون تاريخ ماجستير - مخطوطة بجامعة عين شمس

$$
\text { - ) } 9 V V-
$$

مـدارج السـالكين بـين

رابعاً : شبكات الانترنت : منازل إيالك نعبد وإيالك نستعين - r أجزاء 1 - http://fa wikipedia.org نشر دار الحديث - القاهرة - بدون تاريخ . 2 - http://ar.rasekhoon.net 